\title{
KAZUSEI AKIYAMA
}

\section{Práticas não-convencionais em medicina no Município de São Paulo}

\author{
Tese apresentada ao Departamento de Medicina \\ Preventiva da Faculdade de Medicina da \\ Universidade de São Paulo para obtenção do \\ título de Doutor em Ciências \\ Área de concentração: Medicina Preventiva \\ Professor orientador: Prof. Dr. Moisés Goldbaum
}




\section{FICHA CATALOGRÁFICA}

Preparada pela Biblioteca da

Faculdade de Medicina da Universidade de São Paulo

Oreprodução autorizada pelo autor

Akiyama, Kazusei

Práticas não-convencionais em medicina no Município de São Paulo

/ Kazusei Akiyama. -- São Paulo, 2004.

Tese(doutorado)--Faculdade de Medicina da Universidade de São Paulo. Departamento de Medicina Preventiva.

Área de Concentração: Medicina Preventiva.

Orientador: Moisés Goldbaum.

Descritores: 1.MEDICINA ALTERNATIVA 2.PAPEL DO MÉDICO

3.CONHECIMENTOS, ATITUDES E PRÁTICA 4.ESTUDOS TRANSVERSAIS

5. QUESTIONÁRIOS/utilização 6.SÃO PAULO(SP)

$\mathrm{USP} / \mathrm{FM} / \mathrm{SBD}-300 / 04$ 
Dedico este Trabalho

aos meus pais,

por aceitarem o não-convencional

e

à saudosa Professora Doutora Hiroko Abe,

fundamental na minha formação científica. 
Gostaria de externar meus profundos agradecimentos aos que se envolveram neste Trabalho:

\title{
Orientação desta Tese
}

Prof. Dr. Moisés Goldbaum

\section{Mentor intelectual}

Prof. Dr. Núbio Negrão

\section{Orientação específica}

Profa. Dra. Lilia Blima Schraiber (antropologia médica)

Prof. Dr. Paulo Rossi Menezes (estatística e metodologia)

Prof. Dr. Ysao Yamamura (metodologia)

Profa. Dra. Madel T. Luz (metodologia)

Profa. Dra. Joana Azevedo da Silva (língua portuguesa)

\section{Comentários sobre o assunto estudado}

Professores e colegas da Pós-graduação do Departamento de Medicina Preventiva da

Faculdade de Medicina da USP e do

Ambulatório Geral Didático do Hospital das Clínicas da Faculdade de Medicina da USP

\section{Apoio para realização do teste-piloto}

Departamento Médico do Hospital Universitário da Universidade de São Paulo

\section{Execução metodológica}

Psicóloga Silvia Venske (coordenação)

Amanda de Sales Cunha (secretaria)

Também agradeço pelo(a)

\section{Carinho e amizade}

Aos professores, funcionários e colegas da Pós-graduação do Departamento de Medicina Preventiva da Faculdade de Medicina da USP

\author{
Paciência \\ À minha família \\ aos meus pacientes \\ e às minhas assistentes
}

\section{Colaboração}

A todos os médicos que participaram deste estudo e a todos outros que de alguma forma colaboraram com este Trabalho 
Este Trabalho recebeu

Bolsa do Programa de Demanda Social da

Coordenação de Aperfeiçoamento de Pessoal de Nível Superior (CAPES) do Ministério de Educação

Também recebeu financiamento parcial das seguintes instituição e empresas para execução da parte metodológica:

Instituto Ajinomoto de Assistência

Marubeni Brasil S.A.

Rede Companhia Securitizadora de Créditos Financeiros S.A.

Nisshinbo do Brasil Indústria Têxtil Ltda.

Bioaccus Comércio de Produtos Terapêuticos Ltda.

Tilibra S.A. 
The erosion of Western biomedicine is discernible as a legitimate social process. Not only is there some despair in its inability to "cure" the ever increasing number of chronic diseases, but its apparent lack of success in other spheres, such as psychiatric illness, creates a sense of despondency among its adherents. There is also an increasing awareness that financial investment in health research is not necessarily rewarded by increasing life expectancy nor does it necessarily lead to greater general health.

R. Kenneth Jones* 


\section{SUMÁRIO}

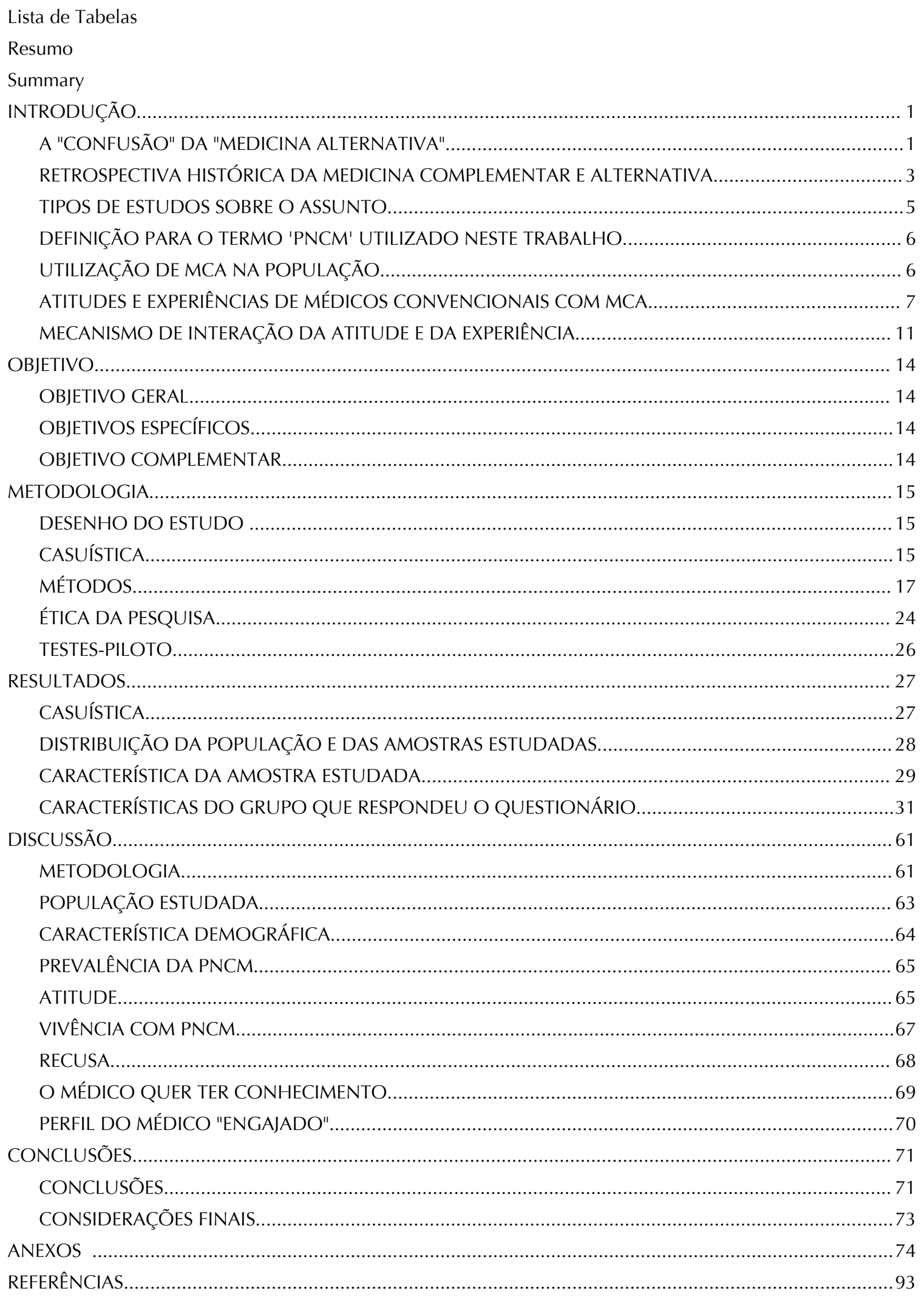




\section{LISTA DE TABELAS}

Tabela 1: Sumário da freqüência de confiança, encaminhamento e prática de cinco tipos de MCA.....

Tabela 2: Variação da freqüência de prescrição e provisão de MCA em serviço de medicina primária na Inglaterra 1995-2001.

Tabela 3: Proporção da distribuição do número de inscrição no CRM da população e das amostras estudadas, valores em \%

Tabela 4: Distribuição do sexo da amostra estudada. Ocorrência, n e \%....................................... 29

Tabela 5: Característica demográfica da amostra estudada: idade por participação..................................30

Tabela 6: Área de atuação do médico na amostra estudada, n e \%....................................... 30

Tabela 7: Características da amostra estudada: dados demográficos por sexo. n e \%............................. 31

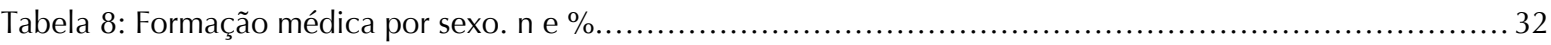

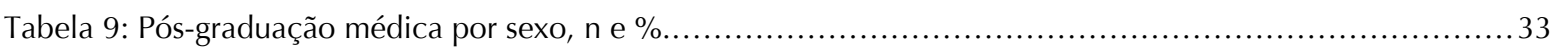

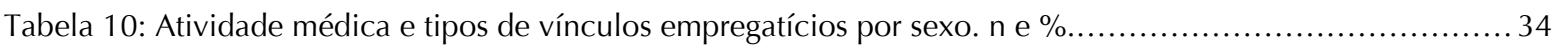

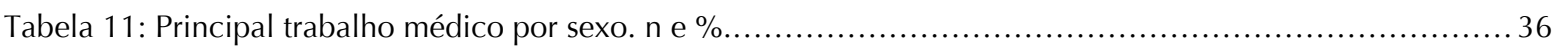

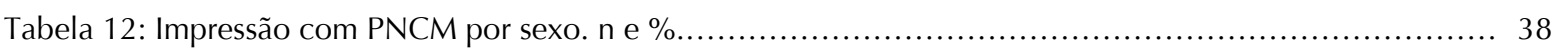

Tabela 13: PNCM são boas ou ruins? Para paciente, médico e resultado, por sexo. n e \%..........................39

Tabela 14: Experiência do médico com PNCM: treinamento, anamnese, endosso e provedor, $\mathrm{n}$ e $\% \ldots \ldots \ldots \ldots \ldots 40$

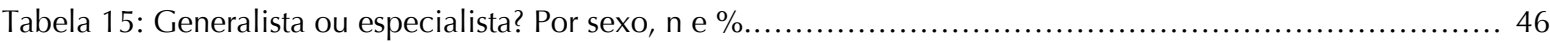

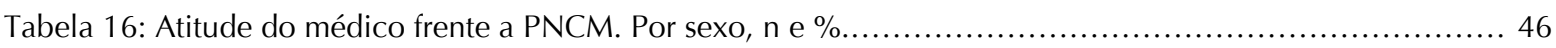

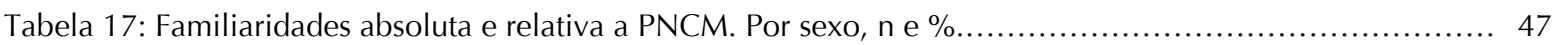

Tabela 18: Associação simples de variáveis de interesse com características demográficas....................... 52

Tabela 19: Modelo de regressão ajustado para variáveis que influenciam o desfecho 'atitude ante PNCM' ....... 53

Tabela 20: Modelo de regressão ajustado para variáveis que influenciam o desfecho 'prescreve ou endossa uso de PNCM'.

Tabela 21: Modelo de regressão ajustado para variáveis que influenciam o desfecho 'provedor de PNCM'...... 55

Tabela 22: Modelo de regressão ajustado para variáveis que influenciam o desfecho 'treinamento em PNCM'.... 56

Tabela 23: Atitude ante PNCM X Percebe demanda por PNCM, n, \% coluna e \% linha......................... 57

Tabela 24: Percebe demanda X Opinião se PNCM: (1) influencia resultado para o paciente, (2) altera o trabalho do

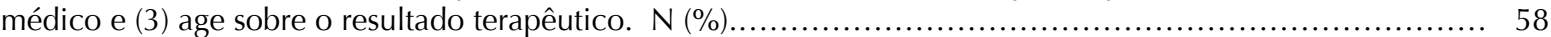

Tabela 25: Faz perguntas sobre PNCM na anamnese X prescrição, provedor, percepção da demanda e treinamento em PNCM. n e \%. 


\section{RESUMO}

Nos países ocidentais, a chamada medicina complementar e alternativa (MCA) vem recebendo crescente atenção entre a classe médica devido ao aumento de seu uso pela população. São tipos de práticas de diagnóstico e de cuidados relacionados à saúde que coexistem paralelamente em nosso meio, sendo a maior parte delas, não-regulamentada. Existem poucos estudos sobre o assunto; nos países industrializados, a prevalência de utilização chega a $40 \%$ na população geral. Este trabalho procura identificar as atitudes e as experiências sobre MCA entre os médicos domiciliados no Município de São Paulo. É um estudo populacional, descritivo e transversal de uma amostra aleatória de 537 profissionais, de todas as especialidades. Para tanto, foi utilizado um questionário específico, aplicado por meio de contato telefônico, entre outubro de 2002 e fevereiro de 2003. A taxa de resposta foi de $68 \%$. A amostra foi representativa da população estudada, sendo composta de 80 tipos de especialidades e subespecialidades médicas. Para cada três médicos, houve um do sexo feminino. O grupo que se recusou a responder o questionário era composto de médicos com mais idade, de especialidades cirúrgica e tocoginecologia. Os resultados apontam que a MCA é prevalente no cotidiano do médico paulistano; $87,6 \%$ referiram perceber demanda por parte dos pacientes; 5,8\% referiram não ter tido contato profissional com MCA; no plano privado, 1,8\% referiram não ter tido contato próprio ou de algum familiar próximo. Metade dos médicos mostrou atitude positiva com a MCA; 52\% endossam ou prescrevem algum tipo; $20 \%$ referem treinamento e 13\% informam ser provedores, de pelo menos uma modalidade de MCA. Ao serem indagados sobre a influência das MCA, 61,5\% opinaram que há influência positiva para o resultado terapêutico do paciente; $42,8 \%$ acham que essas práticas alteram positivamente o trabalho do médico; 61,9\% entendem que causam alguma ação sobre o resultado terapêutico. Sessenta e quatro por cento dos médicos sentem pouca ou alguma familiaridade com as MCA. As modalidades que os entrevistados mais referiram conhecimento foram: acupuntura, homeopatia, terapias em grupo, dietas alternativas e massagem. Noventa e um por cento concordaram que é importante o médico ter algum conhecimento em MCA; 69,5\% discordaram que devam ser combatidas pela classe médica; $85,4 \%$ acharam que devem ser utilizadas somente se forem científicas. Quanto ao treinamento, mais de $60 \%$ acharam importante recebê-lo, inclusive na formação médica. Menos de 30\% dos médicos referiram fazer sistematicamente, na anamnese, perguntas sobre o uso corrente ou passado de MCA. A análise de dados através de regressão logística ajustada mostrou que a variável "treinamento em MCA" influencia os desfechos "atitude" (OR= 2,20; IC95\% 1,21-4,03; $\mathrm{p}=0,009)$, "prescreve ou endossa" ( $\mathrm{OR}=4,07$; IC95\% 2,02-8,20; $\mathrm{p}<0,001)$ e "provedor" (OR= 12,76; IC95\% 4,05-40,17; $p<0,001)$. A variável "treinamento" sofreu influência de faixa etária entre 41 e 50 anos $(\mathrm{OR}=8,83$; IC95\% 1,59-49,08; $\mathrm{p}=0,006)$, "contato profissional" (OR=8,59; IC95\% 3,94-18,74; $\mathrm{p}<0,001)$, "contato particular" (OR= 5,59; IC95\% 2,36-13,22; $\mathrm{p}<0,001)$, atuar em pediatria $(\mathrm{OR}=2,68$; IC95\% 1,06-6,77) ou em "outras especialidades" (OR= 3,40; IC95\% 1,25-9,25; $\mathrm{p}=0,014)$, "atitude" $(\mathrm{OR}=2,13 ; \mathrm{IC} 95 \%$ 1,25-3,65; $\mathrm{p}=0,004)$ e "tipos diferentes de pós-graduação" (OR= 1,47; IC95\% $1,01-2,15 ; p=0,044)$.

Descritores: 1.MEDICINA ALTERNATIVA 2.PAPEL DO MÉDICO 3.CONHECIMENTOS, ATITUDES E PRÁTICA 4.ESTUDOS TRANSVERSAIS 5.QUESTIONÁRIOS/utilização 6.SÃO PAULO (SP) 


\section{SUMMARY}

In western countries, the so called complementary and alternative medicine (CAM) has been getting increasing attention among medical doctors, due to the rise of its use among the population. They are kinds of diagnostic and care practice related to health that exist side by side in our environment, being most of them non-regulated. There are few studies about the subject; in industrialized countries, its prevalence reaches about $40 \%$ on the whole population. This paper seeks to identify attitudes and experience about CAM among medical doctors living in São Paulo City. It's a populational, descriptive and cross-sectional study of 537 professionals randomly sampled from all specialties. To do so, it was used a specific questionnaire applied by means of telephone contact between October of 2002 and February of 2003. The response rate was $68 \%$. The sample was a representative one of the studied population, being made up of 80 medical specialties and sub-specialties. For every three medical doctors, there was a female. The group who refused to answer the questionnaire was made up of older medical doctors whose areas are surgery, and obstetrics and gynecology. The results present that CAM is prevalent in - daily life for medical doctors of São Paulo City; 87,6\% have already noticed some kind of interest from their patients; $5,8 \%$ mentioned that they have never had any contact with CAM on their professional field; $1,8 \%$ has never had any personal or familiar contact with it. Half of the medical doctors have shown positive attitude towards CAM; $52 \%$ endorse or prescribe some kind of CAM; $20 \%$ have had trainning and $13 \%$ are providers of, at least one kind of, CAM. When they were questioned about the influence of CAM, 61,5\% gave their opinion that there had positive influence on patients' therapeutic results; $42,8 \%$ think that these practices alter medical doctors' work positively; $61,9 \%$ understand that it causes some action in therapeutic result. Sixty-four per cent of all doctors feel a little or some familiarity with CAM. The modality which the interviewees showed a better knowledge were: acupuncture, homeopathy, group therapy, alternative diets and massage. Ninety one per cent agreed that it's important that medical doctors should have some knowledge of CAM; 69,5\% disagreed that they should be opposed by medical doctors; $85,4 \%$ think that they must be used only if they were scientific. As for trainning, more than $60 \%$ think it's important to get it, inclusive under-graduation education. Less than $30 \%$ of medical doctors mentioned that they sistematically ask questions for the patients, in their anamnesis, about the current or past use of CAM. The data through adjusted logistic regression analysis showed the variable "CAM trainning" influence the outcome "attitude" (OR=2,20; IC95\% 1,21-4,03; $\mathrm{p}=0,009)$, "prescribes or endorses" (OR=4,07; IC95\% 2,02-8,20; $\mathrm{p}<0,001)$ and "provider" $(\mathrm{OR}=12,76$; IC95\% 4,05-40,17; $p<0,001)$. The variable "trainning" was influenced by the aged range between 41 and 50 years $(\mathrm{OR}=8,83$; IC95\% 1,59-49,08; $p=0,006)$, "professional contact" (OR= 8,59; IC95\% 3,94-18,74; $\mathrm{p}<0,001)$, "private contact" (OR=5,59; IC95\% 2,36-13,22; $\mathrm{p}<0,001)$, act in pediatrics (OR=2,68; IC95\% $1,06-6,77)$ or in "other specialties" (OR=3,40; IC95\% 1,25-9,25; $p=0,014)$, "attitude" (OR= 2,13; IC95\% $1,25-3,65 ; p=0,004)$ and "different kinds of post-graduation" (OR=1,47; IC95\% 1,01-2,15; $p=0,044)$.

Key words: 1.ALTERNATIVE MEDICINE 2.PHYSICIAN'S ROLE 3.KNOWLEDGE, ATTITUDES, PRACTICE 4.CROSS-SECTIONAL STUDIES 5.QUESTIONNAIRES 6.SÃO PAULO (BR) 


\section{1 - INTRODUÇÃO}

\section{1. - A "CONFUSÃO" DA "MEDICINA ALTERNATIVA".}

Afinal, o que vem a ser "medicina alternativa"? A melhor palavra que podemos atribuir-lhe quando falamos dela, nesse momento, no nosso meio, seria "confusão" ". A palavra confusão significa equívoco, discórdia, falta de concordância, mistura confusa, falta de ordem, bagunça, falta de clareza, deficiência de método, entre outras coisas. Pois, vejamos.

Em termos de denominação, não existe uma definição precisa. Ora ela é 'alternativa', ora é 'complementar' (ou 'natural' ou 'não-ortodoxa' ou 'pitônica'). Em termos de abrangência, não existe uma delimitação clara. Ela pode ser elástica ou restritiva. Depende do ponto de vista do grupo social que usa o termo. Em termos de utilidade, não existe um consenso, é discórdia. Funciona? Quando? Seria ela uma "alternativa à medicina" ou uma "medicina com outras alternativas"? Em termos de método, não existe uma padronização ou um padrão mínimo (standard) ${ }^{2}$. Em termos de efetividade, existe pouca demonstração e documentação neutra da sua ação, positiva ou negativa. Em termos de metodologia, há uma mistura, de algo mais sistemático, mais médico e de algo mais específico, técnicos propedêuticos ou terapêuticos. Algumas têm embasamento racional, outras são curiosas, mágicas. Em termos de distribuição, não é uniforme, não existe em todo lugar. Seu acesso não é democrático, nem é universal. Em termos de regulamentação, não existe uma regra clara e abrangente que regule esse tipo de trabalho. Quem pratica; quem pode praticar; quem consegue praticar? Em termos de prática, não existe uma delimitação clara de quem a usa. Conhecemos muito pouco sobre como ela é praticada.

Quando falamos em 'medicina', obviamente sempre temos dois atores: o usuário, o paciente, a população e o provedor; o médico, o sistema médico. A 'medicina' somente existe porque alguém

con•fu•são: s.f. 3. ato ou efeito de tomar uma pessoa ou uma coisa por outra; equívoco, engano 4. conflito entre duas ou mais pessoas por falta de concordância a respeito de algo; discórdia, desentendimento, briga 7. mistura confusa, desordenada, de seres ou coisas; mixórdia, misturada 8. falta de ordem; desarrumação, bagunça 9. deficiência de método; falta de clareza, de exatidão. Dicionário Houaiss de Língua Portuguesa [2001, pg. 798]

2 na maioria das vezes, 'cada um pensa e faz do jeito que achar melhor'. 
necessita dela, alguém busca alívio para seus problemas de saúde e o outro lado provê a necessidade e alivia seu sofrimento. No meio disso tudo, 'por parte do paciente', nota-se que há uma procura considerável por esse modo 'alternativo' de abordagem que se dá à busca da saúde ${ }^{~}$. Não estamos querendo dizer que para o usuário, os itens colocados acima não significam confusão. Pelo contrário. Mas não tem sido nos 'médicos' que ele, o usuário, tem conseguido, ao menos, uma indicação precisa do que viria a ser e ter acesso seguro à 'medicina alternativa'. O 'médico' também faz parte ativa nessa "confusão" toda, sem dúvida, é um dos atores principais.

Para ilustrar, tomemos como exemplo a publicação da Lei Municipal $n^{\circ} 13.717$, de 8 de janeiro de 2004, do Município de São Paulo que dispõe sobre a implantação das "Terapias Naturais" na Secretaria Municipal de Saúde (Prefeitura do Município de São Paulo, 2004) ${ }^{2}$. A Lei, no seu Artigo 1º, incumbe o Poder Executivo de implantar "as Terapias Naturais para o atendimento da população do Município de São Paulo". Esse instrumento legal define "como Terapias Naturais todas as práticas de promoção de saúde e prevenção de doenças que utilizem basicamente recursos naturais" e "dentre as Terapias Naturais, destacam-se modalidades, tais como: massoterapia, fitoterapia, terapia floral, acupuntura, hidroterapia, cromoterapia, aromaterapia, geoterapia, quiropraxia, ginástica terapêutica, iridologia e terapias de respiração.". Seu Artigo $2^{\circ}$ institui que "para o exercício da função, os profissionais habilitados a exercer terapias naturais citadas no artigo $1^{\circ}$ deverão estar inscritos nos respectivos órgãos de classe existentes no Município, Estado ou País.", o que se pressupõe que existam profissionais habilitados e órgão de classe ${ }^{3}$. A mídia, ultimamente também atenta ao assunto, procurou a classe médica ${ }^{4}$ para comentar essas providências : "CRM critica lei municipal de terapias naturais" diz a manchete da reportagem do jornal O Estado de S. Paulo [2004], "tais técnicas", continua a matéria, "além de jamais terem tido sua eficiência cientificamente comprovada, não são reconhecidas oficialmente". Ainda segundo a reportagem, o presidente do Conselho Regional de Medicina de São Paulo entende que essas terapias não oferecem "atendimento de saúde adequado", podendo "haver prejuízo para a saúde da população", e que "os médicos não podem nem aplicá-las, nem recomendálas, visto que não têm o aval científico dos conselhos de medicina", não podendo "exercer uma prática para a qual não foi treinado". A reportagem aproveita para dar sua contribuição para 'a confusão' pois anota que "a Organização Mundial de Saúde só reconhece como alternativas a homeopatia e a

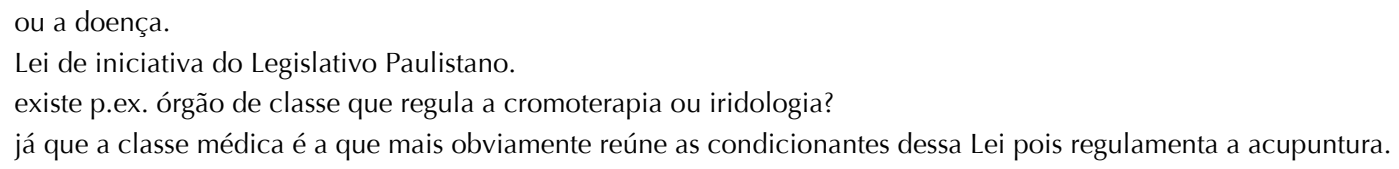


medicina tradicional chinesa". Na verdade, a OMS somente identifica a importância da "Medicina Tradicional ${ }^{1}$ " e diz que sua adaptação nos países industrializados é denominada "medicina alternativa ou complementar" (MCA) [WHO, 2003] 2 . Dessa reportagem, podemos concluir que os médicos então, não conhecem o assunto pois não receberam treinamento, e mesmo se conhecessem, não poderiam praticá-la com exceção dos dois tipos citados, uma vez que a classe não reconhece tais práticas. E esse tipo de discussão que, como vemos, existe, há demanda e causa impacto na sociedade, vem sendo feita ao largo da classe médica. O retrato acima é o contexto, o pano de fundo. Nele, o presente trabalho procurou estudar a atitude do médico ante esta situação e a sua experiência com a "medicina alternativa".

Devemos ressaltar que o presente estudo não faz julgamentos, não defende, não condena, nem recomenda qualquer tipo ou modalidade de MCA.

\section{2. - RETROSPECTIVA HISTÓRICA DA MEDICINA COMPLEMENTAR E ALTERNATIVA}

Nos países industrializados ocidentais, a MCA era, até os anos 1960, considerada um tipo de prática de saúde restrita a certos grupos sociais. Podemos citar, como exemplo, a prática da pajelança, entre os índios americanos; a medicina oriental, na comunidade asiática; os espíritas e o espiritismo; os adeptos à homeopatia, etc. Como a sociedade em geral pouco conhecia ou tinha acesso a essas práticas, eram "desconhecidas", portanto.

Na década de 1960, houve como um movimento global em busca da liberdade: os movimentos sociais, entre os quais o estudantil, o sindical, a busca pela liberação sexual, o culto pela paz, enfim, as mudanças (ou a vontade de mudanças), mais intensamente representadas no movimento Hippie. Nessa época, houve uma maior aproximação com o diferente. Uma dessas buscas relacionavase com a religião, outra com a alimentação e também com as práticas de saúde ${ }^{3}$. A sociedade passa, então, a classificá-las como "curiosas", "estranhas", "exóticas", "misteriosas".

1 refere-se a práticas de saúde, abordagens, conhecimentos e crenças que incorporam remédios baseados em produtos vegetais, animais ou minerais, terapias espirituais, técnicas manuais e exercícios, aplicados sozinhos ou em combinação para tratar, diagnosticar e prevenir doenças ou manter o bem estar, utilizados em países da África, Ásia e América Latina

2 O Conselho Federal de Medicina reconhece a homeopatia e a acupuntura como especialidades médicas e talvez a reportagem fizesse referência a esse fato.

3 Por exemplo, yoga, macrobiótica, fitoterapia, budismo, hinduísmo, meditação, acupuntura, massoterapia, etc. 
Na década de 1970, houve uma incorporação gradativa, desses valores levantados na década anterior. Houve uma mudança evidente nos costumes, mais ou menos dependendo do segmento da sociedade; com maior intensidade nas áreas urbanizadas, nas classes burguesas, menor nas áreas rurais, nas classes aristocráticas. Em termos de MCA, não houve grandes alardes e a classificação continuava a mesma da década anterior.

A situação alterou-se consideravelmente na década de 1980, com a aproximação do novo século, da "nova era", do "fim do mundo". Era o advento do "movimento" New Age. O que esteve incubado na década anterior, exteriorizou-se e houve uma explosão da procura por terapias "alternativas", quaisquer que fossem elas, sérias ou não. Mas, de uma maneira geral, continuavam pouco conhecidas, pela enorme maioria dos médicos até então. Nessa década, os médicos começam a perceber o fenômeno e alguns estudos começam a ser feitos. Seguramente, o trabalho de Aakster [1986] tentando compreender os conceitos da medicina alternativa é um marco na literatura médica (Figura 1). Na literatura médica, as MCA eram denominadas "medicina alternativa", termo mais utilizado pelos adeptos; os mais eufóricos, alegremente, a chamavam também de "natural", "contemporânea", "cultural", "energética", "New Age", etc.

Figura 1: Conceitos das medicinas convencional e alternativa segundo Aakster.

\begin{tabular}{|lll|}
\hline conceito & medicina convencional & medicina alternativa \\
\hline Saúde & ausência de doença & equilíbrio de forças opostas, interna e externamente \\
\hline Doença & $\begin{array}{c}\text { específica, alteração localmente circunscrita aos } \\
\text { órgãos ou tecidos }\end{array}$ & $\begin{array}{c}\text { linguagem corporal indicando forças perturbadoras } \\
\text { e/ou processos restauradores }\end{array}$ \\
\hline Diagnóstico & morfológico & funcional \\
\hline Terapia & combater forças destrutivas & fortalecer forças construtivas \\
\hline Paciente & recipiente passivo de soluções exteriores & participante ativo no processo de reconquista de \\
& & saúde \\
\hline
\end{tabular}

A década de 1990 pode ser caracterizada pela difusão desse tipo de prática, com aumento também no número de praticantes [Vickers, 2000]. A imprensa leiga estimulava o interesse e o assunto passava a fazer parte do cotidiano das pessoas. Houve aumento substancial também de estudos "médicos" e editoriais sobre o assunto. Fontanarosa [2001] cita que "na última década, a taxa de aumento de editorias publicados em revistas médicas é maior do que publicações de ensaios randomizados, sugerindo que o tamanho do interesse e especulação sobre MCA podia estar excedendo o tamanho da pesquisa rigorosamente conduzida. De longe, o trabalho mais citado é o de Eisenberg et al. [1993], publicado no prestigiado Journal of American Medical Association, o qual mostrou que, em 
1990, um terço da população dos Estados Unidos tinha feito uso de algum tipo de tratamento nãoconvencional, com um gasto estimado na casa de 13,7 bilhões de dólares americanos. Quanto à denominação, quando não usados termos pejorativos como "forasteira" [Dalen, 1998], "perigosa" [Murray, Rubel, 1992] ', as qualificações assumiam caráter institucional ou metodológico: "não-oficial", "não-ortodoxa", "não-tradicional", "não-convencional", "baseada em crença", "não-comprovada", etc. No final da década, a tendência na literatura foi pelo uso da denominação "medicina complementar e alternativa" ${ }^{2}$ baseado na noção de uso concomitante (complementar, aditivo) ou não (alternativo, excludente) com a medicina convencional.

A presente década pode ser caracterizada, pelo crescente interesse da classe médica pelo assunto, uma vez que, para os pacientes, não é considerada mais nenhuma novidade ${ }^{3}$. Os médicos, hoje em dia, vêm alguma utilidade na MCA, inclusive como oportunidade para melhoria da medicina como um todo [Straus, 2000]. Existem também tentativas de normatização do seu uso entre os médicos [Sugarman e Burk, 1998]. Atualmente, uma quantidade considerável dos médicos vê a MCA como instrumento que melhora sua performance, tanto terapêutica, como financeira. Com o aumento do interesse, instituições de peso como a Organização Mundial de Saúde têm se preocupado com o uso (e exploração) sustentável de recursos naturais ${ }^{4}$ [WHO, 2002]. Em termos de denominação, além da MCA, surgiu a "medicina integrativa" ${ }^{5}$, com propostas de incorporação à medicina convencional [Rees e Weil, 2001].

De toda maneira, não existe nenhuma dúvida que a crescente demanda por MCA originou-se devido a sua procura pelos pacientes. Não foram os médicos que ofereceram essa "opção" de tratamento ou abordagem. No máximo, os médicos passaram a oferecer essa "opção".

\section{3. - TIPOS DE ESTUDOS SOBRE O ASSUNTO}

Existem dois grandes grupos de estudos sobre MCA: o primeiro é o que procura compreender como ela funciona e o segundo é o que procura entender o quê, como ou por quê é utilizada. A primeira tem duas grandes subdivisões: a) estudo de alguma doença ou situação de saúde e intervenção

\footnotetext{
Outros termos do mesmo tipo: anômala, irregular, etc.

Em inglês, Complementary and Alternative Medicine ou simplesmente CAM.

Se houve novidade, não foi com a existência de MCA mas sim nas variadas modalidades que surgiram nos últimos dez anos.

Comparado com a medicina tradicional, as técnicas utilizadas nas MCA são mais dependentes de recursos naturais.

Do inglês, integrative medicine.
} 
não-convencional e b) estudo ligado a ciência básica como fisiologia, farmacologia, anatomia, para elucidar mecanismos de funcionamento. O segundo também pode ser grandemente divididos em dois vertentes: a) estudo sobre padrão de uso de determinadas modalidades de MCA, em determinada população (geral, um grupo de doentes, uma especialidade, profissionais de saúde, etc) e b) estudo sobre os motivos e aspectos que levam ao uso ou existência de MCA, geralmente relacionado com a sociologia médica ${ }^{1}$. O presente estudo situa-se na primeira subdivisão do segundo grupo.

\section{4. - DEFINIÇÃO PARA O TERMO 'PNCM' UTILIZADO NESTE TRABALHO}

Este estudo utilizará o termo "Práticas Não-Convencionais em Medicina" (PNCM) para designar as MCA, na medida em que estudamos esse termo entre os médicos. Sua definição é institucional. Assim, por PNCM, entendemos aqui, todos os tipos e modalidades de técnicas de diagnóstico, cuidados de saúde ou intervenções terapêuticas que não fazem parte dos currículos acadêmicos da graduação, atualmente, na maioria das escolas médicas brasileiras² .

\section{5. - UTILIZAÇÃo de MCA NA POPULAÇÃo}

Que a MCA tem popularidade e é prevalente na população geral[Goldbeck-Wood et al., 1996], já poderia ser considerado um consenso na classe médica. Lotufo [2001] cita, em editorial de publicação voltada para a classe médica ${ }^{3}$ “(...) não cabe aqui apresentar o que seria 'medicina alternativa' ou 'medicina complementar'. Acredito que se o leitor não sabe defini-la, com certeza saberá reconhecê-la". Estudos realizados em outros países têm mostrado que, pelo menos um terço da população geral de países industrializados vem fazendo uso de alguma modalidade de MCA [Millar, 1997; Astin, 1998; Heidelberg, 2003; Barnes et al., 2004]. Embora não exista estudo populacional geral no Brasil, conforme mostrou Akiyama [1999], o usuário de MCA em São Paulo tem características semelhantes àquelas encontradas na América do Norte; é, assim, bastante razoável supor que a situação seja bastante parecida no nosso meio.

Foram citados exemplos de cada tipo de estudo; não foi feita revisão detalhada de cada um dos tipos de trabalho, por não ser esse objetivo deste estudo.

2 São cerca de 117 escolas médicas no Brasil... Cerca pois não se sabe ao certo o número de escolas que formam médicos já que existem contestações sobre várias delas quanto a sua legalidade e legitimidade (critérios técnicos-educacionais do MEC versus demanda social do Ministério da Saúde). Mas é fato também que são essas instituições que formam pessoal qualificado para o sistema médico formal, de prática convencional.

Revista Diagnóstico \& Tratamento da Associação Paulista de Medicina. 
O usuário de MCA comumente encontrado tem acesso à informação' e dispõe de atitude ativa em busca da saúde² [Spencer e Jonas, 1997; Astin, 1998; Vickers, 2000]. Podemos citar dois grandes motivos que levam esse tipo de usuário a buscar a MCA: o primeiro, "porque quer" e o segundo "porque precisa". Provavelmente, o primeiro grupo deve ter surgido antes, na década de 1960, como vimos anteriormente. Nesse sentido, o advento da MCA pode ser considerado benefício ou conquista para os usuários do segundo grupo, já que ela atende a demandas não resolvidas pela medicina convencional ${ }^{3}$. A Figura 2 mostra os motivos pelos quais os pacientes procuram a MCA [Eisenberg, 1997]. Os dois primeiros motivos são do primeiro grupo e os demais, do segundo.

\section{Figura 2: Padrão de procura pela MCA por parte dos pacientes.}

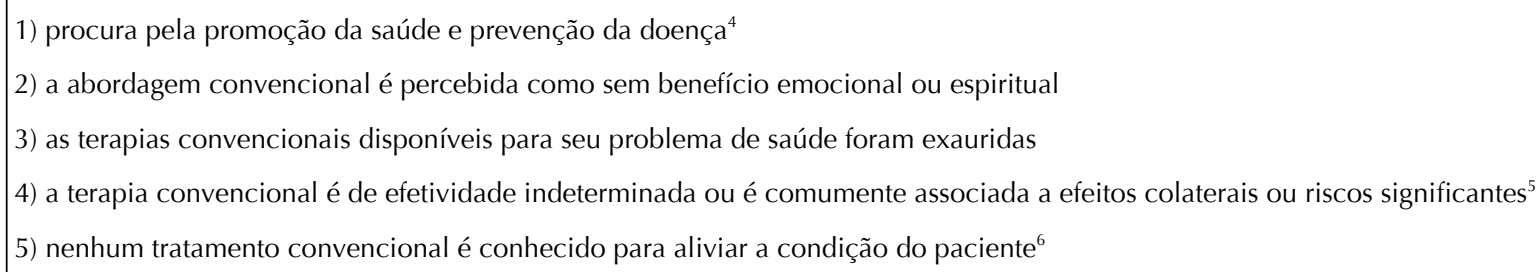

\section{6. - ATITUDES E EXPERIÊNCIAS DE MÉDICOS CONVENCIONAIS COM MCA}

Principalmente os médicos que clinicam, que têm contato com paciente no seu dia-a-dia, vêm sendo "pressionados pela demanda" da MCA, entre os pacientes [Owen, Lewith, Stephens, 2001]. Isso pode ocorrer de maneira direta ou indireta. Diretamente, podemos levantar a questão da interferência, positiva ou negativa, dessas práticas no tratamento prescrito pelo médico. O médico também pode ser indagado sobre a utilidade ou o perigo de uma determinada modalidade de MCA. Mesmo que ele endosse esse tipo de prática, surge o problema administrativo em caso de integração; como seria feito o gerenciamento do tratamento quando há uso concomitante de MCA [Eisenberg, 1997]? Cabe lembrar que a maioria absoluta das modalidades de MCA não são reconhecidas legalmente. Assim, indiretamente, mesmo que o médico "finja" que a MCA não existe, quando os pacientes a usam e há problemas de saúde com isso, ele poderia ser responsabilizado pelo insucesso do tratamento

Significa ter condições de acesso à informação, ou seja, possui escolaridade e renda compatível.

Esse tipo de público não espera passivamente o que é oferecido pelo sistema médico tradicional e faz uso de várias modalidades de práticas que "melhoram o bem estar". Também tem uma visão mais holística do corpo.

3 Como exemplo podemos citar o uso de MCA por pacientes com diagnóstico de AIDS, na primeira metade dos anos 1990, quando a terapia antiretroviral ainda não havia sido instituída.

Astin [1998] notou que os usuários de MCA referem status de saúde pior que os não-usuários.

As doenças de maior ocorrência são: dor crônica, ansiedade, tensão muscular, problemas de dependência, artrite e cefaléia.

6 Como, por exemplo, a síndrome da fadiga crônica. 
convencional [Studdert et al. 1998]? E daqueles que aceitam a MCA, é ético encaminhar o paciente a um tratamento não-regulamentado ${ }^{1}$ ?

É interessante notar a transformação da atitude da classe médica através de artigos de revistas médicas respeitadas. Em 1992, Visser, Peters, Rasker assinaram um trabalho no qual evidenciavam bastante ceticismo quanto à MCA. O artigo de Campion, em 1993, versava sobre a preocupação com a MCA. Já em 1997, Beyerstein chamava pela cautela. E em 1998, Best e Herbert mostravam o interesse pela incorporação da MCA, na mesma linha, o editorial de Lotufo, em 2001. É bom deixar claro que, mesmo os médicos mais interessados, sempre lembram que a utilidade da MCA não está em toda ela mas em parte dela. Algumas modalidades são mais aceitas que outras e estão em estágio mais avançado de reconhecimento da classe médica. No nosso meio, seriam elas a homeopatia e a acupuntura, regulamentadas respectivamente, em 1980 e 1995, pelo Conselho Federal de Medicina, como especialidades médicas.

Em uma breve revisão de literatura sobre a atitude e experiência de médicos com a MCA, ressaltamos dois artigos escolhidos da seguinte maneira: o primeiro, de Astin et al. [1998] é um artigo de revisão, o que traz enormes vantagens ao estudo do tema. O segundo [Thomas, Coleman, Nicholl, 2003] é um estudo de seguimento, que permite verificar tendências ao longo do tempo, no caso na Inglaterra em 1995 e 2001.

Astin et al. publicaram, em 1998, um artigo de revisão de 19 artigos com estudos conduzidos entre 1982 e 1995, em países industrializados². Todos os trabalhos foram publicados na língua inglesa, eram artigos originais. Os dados foram coletados por meio de questionários e tiveram a taxa de resposta igual ou maior que 50\%. As modalidades de MCA consideradas para revisão foram cinco ${ }^{3}$ : acupuntura, quiropatia, homeopatia, fitoterapia ${ }^{4}$ e massagem. Os fatores específicos estudados nessa revisão foram três: 1) prática, treinamento e tipos de encaminhamento em geral; 2) confia na eficácia e ou faz uso e 3) razões da prática, do encaminhamento e/ou do interesse. Nenhum dos trabalhos tinha teste de confiabilidade do questionário. O tamanho de amostra variou entre 40 e 594 (201 \pm 141$)$. A maioria dos

\footnotetext{
Nem vamos discutir aqui sobre aqueles médicos que são os próprios provedores de práticas não-regulamentadas!

A saber, Estados Unidos (5), Inglaterra (3), Canadá (3), Nova Zelândia (2), Países Baixos (2), Israel (2), Escócia (1), Alemanha (1), Suécia (1). O total é maior que 19, pois um dos trabalhos foi multicêntrico.

Outras MCA estudadas que não foram consideradas na revisão foram: terapia nutricional, jejum, meditação, relaxamento, hipnose, cura espiritual, osteopatia, terapia polar, cura eletromagnética, quelação, acupressão, reflexologia e terapia por toque.

4 Aqui se refere a fitoterapia européia (herbal medicine).
} 
trabalhos incluíram médicos de área delimitada, o que faz com que não seja possível generalizar os resultados. A taxa de resposta foi de $72 \% \pm 10,4$ (variando entre 52 e 89). Quatro artigos estudaram também o treinamento em MCA e mostraram que, com algumas exceções, um número igual ou maior que aqueles que praticam referiram possuir treinamento em vários tipos de MCA. Somente um dos artigos estudou a parte da amostra que recusou participação; o mesmo aconteceu com o estudo de especialização do médico. A freqüência da prática, do encaminhamento e da confiança variou entre cada trabalho e entre as 5 modalidades de MCA estudadas. A Tabela 1 mostra as freqüências encontradas.

Tabela 1: Sumário da freqüência de confiança, encaminhamento e prática de cinco tipos de MCA.

\begin{tabular}{|c|c|c|c|c|c|c|c|}
\hline \multirow[b]{4}{*}{ acredita } & \multicolumn{7}{|c|}{ Tipo de MCA (\%) } \\
\hline & \multicolumn{7}{|c|}{ média $\pm D P$ mediana amplitude } \\
\hline & acupuntura & quiropatia & homeopatia & \multicolumn{2}{|c|}{ fitoterapia } & \multicolumn{2}{|c|}{ massagem } \\
\hline & $51 \pm 26 \quad 49 \quad 15-88$ & $53 \pm 26 \quad 49 \quad 13-91$ & $26 \pm 19 \quad 25 \quad 1-52$ & $13 \pm 9$ & $15 \quad 1-23$ & $48 \pm 38 \quad 58$ & $6-68$ \\
\hline encaminha & $43 \pm 22 \quad 47 \quad 8-71$ & $40 \pm 23 \quad 50 \quad 2-83$ & $15 \pm 14 \quad 10 \quad 1-42$ & $4 \pm 3$ & $4 \quad 0-9$ & $21 \pm 14 \quad 24$ & $1-35$ \\
\hline pratica & $17 \pm 15 \quad 15 \quad 1-51$ & $19 \pm 14 \quad 18 \quad 6-51$ & $9 \pm 13 \quad 5 \quad 1-45$ & $16 \pm 30$ & $5 \quad 0-78$ & $19 \pm 18 \quad 22$ & $0-35$ \\
\hline
\end{tabular}

Os tipos de trabalhos revisados têm as seguintes limitações:

1) vários têm baixa taxa de resposta, o que pode causar viés de resposta pois apenas os mais entusiastas (positivos ou negativos) podem ter respondido o questionário;

2) para verificar o item acima há necessidade de fazer a revisão da parte da amostra que não respondeu, o que somente foi feito em um trabalho;

3) o desenho dos estudos, com questionários enviados pelo correio, é mais suscetível à limitação 1;

4) não foi tomado o cuidado de se fazer validação interna dos trabalhos;

5) o estudo transversal não permite generalização dos dados, nem mostra tendências.

Desse modo, devemos levar em consideração que, possivelmente, a freqüência elevada encontrada em alguns trabalhos prova que o item 1) foi observado. Justamente por esse motivo, os autores da revisão expressam que, para os próximos estudos, sejam seguidas as seguintes recomendações: a) ter uma amostra mínima de 50 profissionais; b) essa amostra deve ser aleatória; c) fazer teste de confiabilidade do questionário e d) procurar formas de ter ao menos $75 \%$ de taxa de resposta. De toda forma, as conclusões mostradas na Figura 3 podem ser identificadas. 
Figura 3: Atitudes e experiências de médicos sobre a PNCM.

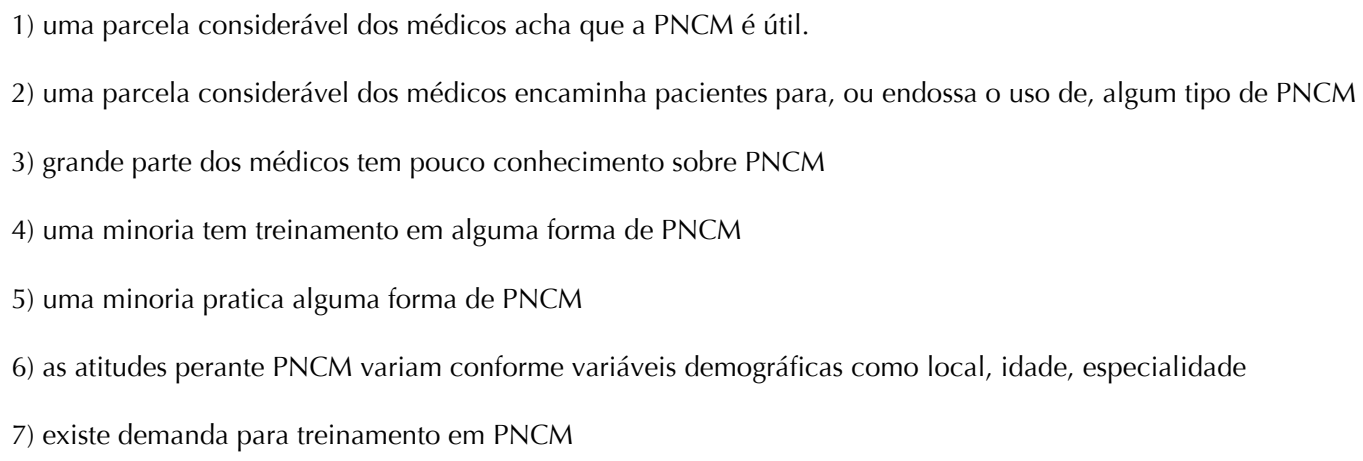

Em trabalho publicado em 2003, Thomas, Coleman, Nicholl realizaram um estudo de seguimento, na Inglaterra, entre clínicos gerais, em 1995 e em 2001. A mesma metodologia foi empregada nas duas coletas realizadas por meio de questionário postado para amostra de clínicos gerais, aleatoriamente escolhidos. Em caso de não resposta até três tentativas, uma quarta correspondência foi postada para estudar o grupo que recusou participação. A taxa de resposta foi de 72,3\% em 2001 e 78,6\% em 1995. O estudo mostrou que houve aumento de 38\% no número de médicos que prescreveram alguma modalidade de MCA, de 39,5\% para 49,4\%. A MCA prescrita, provida no próprio serviço médico, passou de 21,4\% para 29,6\%. Tanto a freqüência da prescrição, como da provisão dependeram do tipo de MCA, bem como seu aumento. A Tabela 2 resume os resultados encontrados. Notamos um aumento do número de provedores de acupuntura e outras MCA e também chama a atenção a taxa de aumento, no período, de prescrição em quiropatia.

Tabela 2: Variação da freqüência de prescrição e provisão de MCA em serviço de medicina primária na Inglaterra 1995-2001.

\begin{tabular}{|c|c|c|c|c|c|c|c|c|}
\hline \multirow[b]{3}{*}{ prescreveu } & \multicolumn{8}{|c|}{$\begin{array}{l}\text { Variação da freqüência (\%) } \\
1995 \text { e } 2001\end{array}$} \\
\hline & acupuntura & homeopatia & \multicolumn{2}{|c|}{ quiropatia } & \multicolumn{2}{|c|}{ fitoterapia } & \multicolumn{2}{|c|}{ outras } \\
\hline & $21,2 \quad 33,6$ & $16,8 \quad 21,1$ & 7,1 & 23,0 & 1,5 & 2,7 & 5,1 & 6,4 \\
\hline proveu & $12,5 \quad 20,5$ & $6,7 \quad 8,3$ & 2,0 & 3,3 & $<1$ & $<1$ & 1,8 & 3,0 \\
\hline
\end{tabular}

Observamos que o estudo tomou vários cuidados metodológicos, como sorteio, abrangência nacional, insistência e reforço, o que resultou em baixa taxa de recusa e estudo de recusas, fazendo com que o resultado seja de grande confiabilidade. No serviço primário inglês, em 2001, portanto, a metade 
dos médicos prescrevem, pelo menos, uma forma de MCA e quase $30 \%$ dos serviços oferecem alguma modalidade de tratamento com MCA.

\section{7. - MECANISMO DE INTERAÇÃO DA ATITUDE E DA EXPERIÊNCIA}

A atitude e a experiência interagem mutuamente. Essa interação, entretanto, não é de via simples, existe um terceiro elemento conhecido como opinião, por onde esse relacionamento também passa (Figura 4). Antes de discorrer sobre o relacionamento, definiremos cada um dos termos, com base no Dicionário Houaiss da Língua Portuguesa [2001]:

“Atitude 1 pose, posição, postura 2 comportamento ditado por disposição interior; maneira de agir em relação a pessoa, objeto, situação, etc.; maneira, conduta 3 posição assumida, orientação, modo ou forma de proceder $\mathbf{5}$ propósito ou modo de se manifestar esse propósito $\mathbf{9}$ estado de disponibilidade psicofísica marcado pela experiência e que exerce influência diretiva e dinâmica sobre o comportamento

Experiência 2 qualquer conhecimento obtido por meio dos sentidos 3 forma de conhecimento abrangente, adquirida de maneira espontânea durante a vida; prática 4 forma de conhecimento específico, ou de perícia, que, adquirida por meio de aprendizado sistemático, se aprimora com o correr do tempo; prática 5 tentativa, ensaio, prova

Opinião 1 maneira de pensar, de ver, de julgar; asserção, afirmação que o espírito aceita ou rejeita 2 julgamento pessoal que se tem sobre determinada questão; parecer, pensamento 3 posição precisa, ponto de vista que se adota em um domínio particular; idéia, teoria, tese $\mathbf{4}$ parecer, julgamento emitido após reflexão ou deliberação; voto, partido 5 hipótese, idéia não verificada ou sem fundamento; presunção 6 julgamento de valor sobre alguém ou algo; conceito 7 convicção, julgamento coletivo; conjunto de idéias partilhadas por um grupo, por uma coletividade a respeito de um assunto particular ou de uma série de temas; consenso 8 crença adotada como verdade pelo senso comum sem qualquer reflexão a respeito de sua validade, de seus pressupostos e dos meios pelos quais foi obtida" 
Figura 4: Mecanismo de interação entre atitude, experiência e opinião.

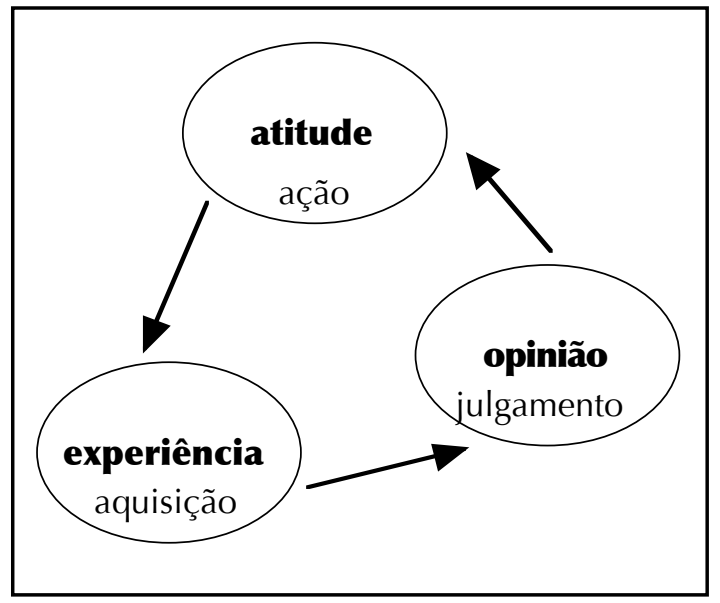

O relacionamento das três partes dá-se conforme o movimento circular acima. Elas estão interligadas pelas partes grifadas (grifos do autor) da definição de cada um dos termos ${ }^{1}$. Suponhamos que um indivíduo tenha uma opinião "boa" sobre uma situação "S". A atitude desse indivíduo quando indagado sobre " $\mathrm{S}$ " será seguramente positiva. Assim, quando ele se vir diante de "S", primeiro, não recusará passar por "S" e segundo, tendo (ou confirmando) uma experiência positiva esta irá dar retroalimentação positiva para a opinião. Seria um círculo virtuoso cognitivo. O inverso também é válido, o mesmo raciocínio começando com uma opinião "ruim" sobre a situação "S". A atitude desse indivíduo sobre " $\mathrm{S}$ " será provavelmente negativa. Desse modo, diante de "S", pode ser que não queira passar por "S", o que cortaria o círculo ou a experiência com "S" sendo negativa, retro-alimenta de maneira negativa a opinião, confirmando-o². O indivíduo pode passar por alguma experiência " $\mathrm{E}^{\prime}$, que surpreendentemente pode ser o contrário de sua opinião. Essa situação pode "abalar" a opinião, fazendo com que mude a atitude quando se vir frente a " $E$ " novamente.

A atitude, inegavelmente, é influenciada pela opinião e a experiência pela atitude. E a opinião? Seria ela influenciada pela experiência em mesmo grau? A opinião, conquanto parte mais forte, aparentemente, do círculo em questão, na verdade, contém uma grande incoerência no seu seio já que convivem as definições 2 e 5 e também as 7 e 8. Seria a parte mais subjetiva desse elo. Le Bon [2002, p.24] entende que "a crença orienta os pensamentos, as opiniões e por conseguinte, a maneira de

\footnotetext{
Simplificamos ao máximo esse tipo de explicação, uma vez que o autor não tenta discorrer neste trabalho sobre epistemologia, hermenêutica ou antropologia...

2 Diferença entre "comi e não gostei" e "não comi e não gostei". São atitudes completamente diferentes.
} 
$\operatorname{proceder}^{1}(\ldots)$ essa origem inconsciente e, portanto, involuntária das crenças, torna-as muito fortes."

Do mesmo autor [Le Bon, 2002; p.177]:

As opiniões não têm, geralmente, a fixidez das crenças. Elas são mesmo, freqüentemente, tão móveis que a sua retificação pareceria fácil: observa-se, entretanto, o contrário. Os dois métodos de retificação das opiniões que se apresentam, primeiramente, ao espírito, são a razão e a experiência.

Forma-se, desse modo, novamente, o círculo de interação.

A Figura 5 mostra os fatores que compõem a crença segundo esse autor.

Figura 5: Fatores que compõem a crença segundo Le Bon.

\begin{tabular}{|c|c|}
\hline fatores internos & fatores externos \\
\hline o caráter & a sugestão \\
o ideal & as primeiras impressões \\
as necessidades & a necessidade de explicação \\
o interesse & os vocábulos, as fórmulas e as imagens \\
as paixões & as ilusões \\
& a necessidade \\
\hline
\end{tabular}

1 É a atitude. 


\section{2 - OBJETIVO}

\section{1. - OBJETIVO GERAL}

O principal objetivo deste trabalho é identificar, entre os médicos domiciliados no Município de São Paulo, suas atitudes e experiências sobre práticas não-convencionais em medicina.

\section{2. - OBJETIVOS ESPECÍFICOS}

- Avaliar a atitude do médico com relação a práticas não-convencionais, em medicina;

- identificar a presença de práticas não-convencionais em medicina na rotina do médico, estimar sua freqüência e treinamento, estudar sua particularidade;

- verificar a experiência e conhecimento do médico em práticas não-convencionais em medicina.

\section{3. - OBJETIVO COMPLEMENTAR}

- testar instrumentos e métodos de pesquisa populacional: coleta de dados, por meio de telefone, em população de médicos 


\section{3 - METODOLOGIA}

\section{1. - DESENHO DO ESTUDO}

É um estudo populacional, descritivo e transversal, de uma amostra da população de médicos.

\section{2. - CASUÍSTICA}

O estudo contemplou uma amostra aleatória de todos os médicos domiciliados no Município de São Paulo e regulamente inscritos ${ }^{1}$ no Conselho Regional de Medicina do Estado de São Paulo (CRM). Como instituições reguladoras e representantes da classe médica², o CRM e a Associação Paulista de Medicina (APM), foram procurados formalmente para solicitar apoio ao estudo, a saber, fornecimento de endereço e telefone dos mil médicos sorteados conforme veremos em Metodologia. Ambos decidiram não participar alegando motivos diversos ${ }^{3}{ }^{4}$. Discutiremos essa não-participação posteriormente, e agora descreveremos o método utilizado para se chegar na amostra. A Figura 6 (página 17) resume os termos relativos à amostra.

\subsection{1. - Cálculo da amostragem}

A população-alvo era constituída de 37.686 indivíduos, no momento do estudo. Era composta de médicos ativos, domiciliados na Capital, em junho de 2002, segundo o Departamento de Estatística do CRM. A característica mais importante da população foi o fato de estarem com o "número do CRM" utilizável $^{5}$, o que mostra intenção de trabalhar como médico, recebendo ou não aposentadoria.

Consideramos uma perda de amostragem de $45 \%$, índice obtido através de dois testes-piloto realizados anteriormente (veja em Testes-piloto). Tal perda ocorre tanto decorrente da impossibilidade

1 São aqueles que estão em dia com suas obrigações junto ao Conselho, habilitando-os para a prática da medicina. No CRM são denominados 'médicos ativos'.

2 Procuramos estudar a prática da medicina, desse modo foram escolhidos o órgão fiscalizador e a associação de classe. O sindicato não foi incluído já que é uma instituição mais voltada para as relações do trabalho.

3 O CRM evocou uma Resolução do Conselho Federal de Medicina, que proíbe a divulgação de dados cadastrais de médicos salvo sob expressa autorização do próprio e não entrou no mérito do assunto abordado.

4 A APM também evocou decisão da Assembléia de Delegados que proíbe a divulgação de dados cadastrais dos sócios e se dispôs a ceder onerosamente um Mailing List.

5 Pois estão "regularmente inscritos no Conselho" e aptos para a profissão (do ponto de vista do 'credenciamento'). 
de acesso aos dados demográficos do indivíduo estudado, como do insucesso do contato. Com isso, estimamos uma amostra inicial de mil indivíduos para se encontrar 550 indivíduos. Esse número está próximo de 530, valor que consegue ter nível de confiança de 95\% para freqüência esperada de $15 \% \pm 3 \%$ (programa Statcalc - Epiinfo ver. 6.0, CDC-WHO). No caso, a freqüência esperada seria do 'médico provedor de práticas não-convencionais em medicina', uma das variáveis de grande importância que foi investigada no presente estudo. Em estudos desenvolvidos em outros países, esse gira em torno de 16\%, conforme vimos no Capítulo Introdução. O questionário foi desenhado para ser sensível a essa variável e consideramos a freqüência do médico-provedor de medicina não convencional algo entre $12 \%$ e $18 \%$. As demais variáveis de interesse apresentam freqüências maiores.

\subsection{2. - Técnica para se chegar na amostra efetiva}

Os dados aos quais tivemos acesso foram o nome e o número de inscrição no CRM. Assim, os 37.686 indivíduos foram reordenados por ordem alfabética e, a cada um, foi atribuída numeração seriada de 00001 a 37686. Com isso, obtivemos um número contínuo'; desses foram, então, sorteados mil números (Programa Epitable/Epiinfo ver. 6.0, CDC-WHO).

Entre junho e julho de 2003, procuramos, através da Internet e em mídia publicada, o telefone e o endereço dos indivíduos dessa amostra. Em primeiro lugar, pesquisamos no site do $\mathrm{CRM}^{2}$. Os indivíduos para os quais constava o dado de interesse foram pesquisados na lista telefônica do município de São Paulo, também através da Internet, no site da companhia Telefônica ${ }^{3}$. O nome completo do profissional foi digitado no campo 'nome do assinante'. Quando a lista retornava menos do que 19 números com endereços diferentes, checamos um-a-um telefonando-lhes. Quando retornava 20 ou mais, esse profissional foi incluído no mesmo grupo de indivíduos não encontrados com a Metodologia.

1 Com essa técnica, evitamos sortear o número do CRM que não é contínuo pois apesar de ser atribuído seqüencialmente, parte dos médicos passou para a inatividade.

2 No serviço de procura de médicos encontrado na página inicial do site www.cremesp.org.br. Pode ser feita por nome ou no CRM que retorna o endereço autorizado para publicação. Quando não tem endereço disponível, retorna o nome do município domiciliado. Em junho de 2002, foram encontrados em:

[http://www.cremesp.org.br/servicos/pesquisa_medicos/resultado_guia_medico.php].

3 Telefônica é a ex-estatal Telesp, companhia predominante na rede de telefonia fixa em São Paulo. Pesquisamos no serviço de lista tefelônica online, da seção 'Serviços Online'. Como se trata de lista de todos os assinantes da companhia, no campo de busca, além do nome completo, sempre colocamos nome da cidade = 'São Paulo'. Na época da aplicação da metodologia, foram encontrados em: [http://www.telefonica.net.br/online/guias/]. 


\subsection{3. - Fatores de exclusão}

Os indivíduos que encontramos nas condições a seguir listadas foram considerados também 'perdas' por serem classificáveis nos seguintes fatores de exclusão:

1 - embora haja chamada na linha telefônica, ninguém atende;

2 - há atendimento de aparelhos como fax ou secretária eletrônica com mensagem genérica';

3 - o telefone conseguido é de uma pessoa homônima;

4 - o médico passou para a inatividade;

5 - mudança de domicílio para fora do Município de São Paulo;

6 - impossibilidade de participação do estudo por problemas de saúde;

7 - falecimento do médico.

Figura 6: Resumo dos termos relativos à amostra.

\begin{tabular}{|ll|}
\hline Amostra Inicial & o universo de 1000 sujeitos sorteados da população médica estudada \\
Amostra Encontrada & o universo de sujeitos encontrados segundo método do presente trabalho \\
Perda & $\begin{array}{l}\text { o grupo de indivíduos da Amostra Encontrada não elegíveis para o estudo, por serem } \\
\text { classificáveis em Fatores de Exclusão mais extravios }\end{array}$ \\
Amostra Estudada & o universo de sujeitos efetivamente estudados; é a Amostra Encontrada menos Perda \\
Recusa & o grupo de indivíduos da Amostra Estudada que não participaram do estudo
\end{tabular}

\section{3. - MÉTODOS}

O método usado foi a aplicação de questionário por meio de contato telefônico.

Os dados obtidos foram analisados estatisticamente.

\subsection{1. - Instrumento um: o questionário}

Elaboramos um questionário especificamente para o estudo, baseado em trabalhos publicados e na metodologia quantitativa. Foi constituído com 32 perguntas fechadas, semi-abertas e abertas. As

1 Por 'mensagem genérica' entende-se aquelas gravações pré-estabelecidas no aparelho ou no serviço de telefonia que não permitem identificar o indivíduo. P.ex., mensagem padrão do serviço de caixa postal de celular: "você ligou para um-um-xyz que não pode atender no momento; após o sinal, grave sua mensagem". 
perguntas fechadas eram, na maioria das vezes, constituídas de variáveis dicotômicas do tipo sim/não; algumas tinham variáveis ordenadas ou variáveis nominais. Na avaliação da 'atitude', foi utilizada uma questão com respostas em escala de Likert de cinco pontos.

O questionário constava de quatro partes, sendo a primeira para caracterização demográfica, a segunda para avaliar a atitude sobre práticas não-convencionais em medicina, a terceira para definir a experiência do médico com relação ao assunto e a quarta para identificar conhecimento a algumas práticas não-convencionais. As variáveis estudadas encontram-se descritas na Figura 7 (pg.19); o questionário está no Anexo A. Tomamos um cuidado especial com o desenho do questionário no quesito 'ser aplicável' por meio de conversa telefônica' uma vez que o telefone foi um instrumento chave neste estudo.

\subsection{2. - Instrumento dois: o telefone}

Até meados da década de 1990, o telefone tinha pouca penetração na população geral. Por esse motivo, o uso do telefone não mostrou desenvolvimento aceitável em pesquisas populacionais no Brasil. Nos últimos oito anos houve um aumento considerável da planta telefônica, passando de 9,4 acessos a telefone fixo por cem habitantes em 1996 para 22,1 em 2001, e no serviço móvel celular de 1,7 acessos por cem habitantes em 1996 para 17,0 em 2001 [ANATEL, 2002]. Esses números ainda estão longe de valores como 80 acessos/cem habitantes encontrados em países desenvolvidos. Entretanto, podemos considerar que está havendo reais condições de facilidade de acesso a um terminal telefônico. Também é fácil imaginar que o médico tenha maior necessidade de ter um telefone devido a peculiaridades da profissão ${ }^{2}$.

Apesar de suas limitações, que serão vistas no Capítulo Discussão, o uso do telefone em estudos populacionais tem duas vantagens quando comparado com a entrevista face-a-face: 1) baixo custo e 2) rapidez na coleta de dados. Ambos fatores permitem acesso a um número maior de indivíduos em menor espaço de tempo e para um dado orçamento. Como existe essa vantagem, como estamos estudando um grupo populacional homogêneo, caso dos médicos, e como está ocorrendo mudança no acesso ao telefone, resolvemos então experimentalmente lançar mão desse instrumento. O número de telefone foi obtido da maneira descrita em Casuística.

\footnotetext{
Enunciados audíveis, compreensíveis ao telefone; frases e perguntas curtas; entrevista sucinta.

Que demanda "ser achado". Antes de meados da década de 90, quando era mais difícil ter um telefone, fixo ou móvel, os médicos faziam uso de pagers, os "bipes".
} 
Figura 7: Variáveis incluídas no questionário. A demografia, a formação e o trabalho fazem parte da característica demográfica da amosta.

\begin{tabular}{|c|c|}
\hline parte & variável \\
\hline demografia & $\begin{array}{l}\text { sexo } \\
\text { idade } \\
\text { local de nascimento }\end{array}$ \\
\hline formação & $\begin{array}{l}\text { escola médica } \\
\text { tempo de formado } \\
\text { número da inscrição profissional } \\
\text { pós-graduação }\end{array}$ \\
\hline trabalho & $\begin{array}{l}\text { vínculos empregatícios } \\
\text { principal vínculo empregatício: tipo, proporção de tempo e local da atividade } \\
\text { nome da atividade médica (especialidade) }\end{array}$ \\
\hline atitude & $\begin{array}{l}\text { posicionamento se generalista ou especialista } \\
\text { opinião a afirmações acerca das PNCM } \\
\text { auto-avaliação: familiaridade absoluta com PNCM } \\
\text { auto-avaliação: familiaridade relativa com PNCM }\end{array}$ \\
\hline experiência & $\begin{array}{l}\text { contato prévio, profissional, com PNCM e impressão do contato } \\
\text { contato prévio, privado, com PNCM e impressão do contato } \\
\text { percebe demanda leiga por PNCM } \\
\text { nota benefícios para o paciente } \\
\text { nota benefícios para o médico } \\
\text { nota utilidade terapêutica } \\
\text { pergunta sobre uso prévio de PNCM na anamnese } \\
\text { recebeu treinamento em PNCM, foi em ambiente acadênico e concluiu } \\
\text { indica o uso de PNCM na prática médica } \\
\text { é provedor de PNCM }\end{array}$ \\
\hline conhecimento & nível de conhecimento referido para PNCM selecionados \\
\hline
\end{tabular}

\subsection{3. - Coleta de dados}

Cada indivíduo da amostra foi contatado, por telefone, por uma das oito entrevistadoras treinadas. A coleta ocorreu durante 5 meses consecutivos entre os meses de outubro de 2002 e fevereiro de 2003, grande parte nos 3 primeiros meses. As 'perdas' foram descartadas e os demais indivíduos foram submetidos à entrevista. O número de telefone e endereço foram utilizados nessa etapa. Como veremos, o endereço foi fundamental na aplicação correta da Metodologia deste trabalho.

3.3.3.1. - Treinamento da equipe de entrevistadoras: A equipe que executou a coleta de dados foi constituída de oito entrevistadoras e uma coordenadora ${ }^{1}$. Este autor ficou com a gerência de

1 Todas do sexo feminino; a coordenadora era psicóloga com mestrado em ciências, as entrevistadoras eram psicólogas recém 
todo o processo. Todas as entrevistadoras foram submetidas a treinamento coletivo de oito horas de duração, no mês de setembro de 2002. Para tal, confeccionamos um 'Manual da Entrevistadora' contendo as linhas gerais e o objetivo da pesquisa, aspectos éticos, definições e padronização dos termos usados (vide Anexo B), fluxograma de conduta e diálogo padronizado.

3.3.3.2. - Procedimentos preliminares à entrevista: Antes do primeiro contato telefônico, enviamos pelo correio ${ }^{1}$ uma carta contendo 1) aviso de que o sujeito fora sorteado para a pesquisa e que seria contatado por telefone, 2) informações a respeito da pesquisa, 3) meios de contato com o pesquisador e 4) documentação referente ao consentimento informado (que será discutido mais adiante em Ética da pesquisa). Esse envio foi providenciado pela Coordenação do presente estudo e ocorreu em lotes para que o sujeito sorteado fosse contatado pela primeira vez dentro de uma semana após o recebimento da correspondência. Para que pudéssemos ter idéia de quando o serviço de correio fez a entrega, em todo lote seguiu uma correspondência para a própria Coordenação, já que toda correspondência foi enviada para endereços do município de São Paulo.

3.3.3.3. - Contato telefônico: Semanalmente, as entrevistadoras retiravam o lote ${ }^{2}$ para contato com a lista de nome e telefone dos sujeitos sorteados. De posse da lista, a equipe telefonava, do local de sua conveniência, ${ }^{3}$ para os médicos. A primeira providência foi marcar horário para falar com o médico. Quando contatávamos pessoalmente o sujeito, após a identificação como pesquisadoras, antes de mais nada, confirmávamos o recebimento da correspondência, sua leitura e seu acordo com os termos do consentimento informado. A entrevista somente era realizada com essa etapa cumprida. Nos casos de não recebimento, a documentação era enviada novamente. Os casos de não concordância com os termos de consentimento ou com a participação no estudo, foram anotadas e o indivíduo incluído no grupo recusa, contabilizado no grupo "recusa direta".

3.3.3.4. - Grau de insistência: Uma vez localizado o indivíduo da amostra, fizemos cinco tentativas de marcação de entrevista. Se em cinco tentativas não tivéssemos conseguido entrevistar o médico, incluíamos esse indivíduo no grupo que recusou a participação, sendo contabilizado no grupo

formadas (quatro) e universitárias de curso de nutrição (quatro).

Em envelope próprio identificando a pesquisa e as cartas em papel timbrado. Foram usados correio comum e tarifa comum. Quando também reportavam o andamento e entregavam os questionários preenchidos.

Geralmente da residência. Resolvemos coletar dessa forma pois, pela prática do médico, nem sempre o sujeito estaria disponível no horário comercial e isso seria um fator limitante da metodologia empregada. O pagamento às equipe foi por produção e incluiu o valor gasto com telefonemas. 
"recusa indireta".

3.3.3.5. - Controle de qualidade dos dados coletados Para controlar a consistência e a confiabilidade dos dados coletados pela equipe, realizamos uma conferência dos mesmos. Após a conclusão da coleta, dez por cento do grupo estudo foram sorteados e novamente contatados por telefone, desta vez pela coordenadora. Aos médicos foram feitas duas perguntas da característica demográfica, ${ }^{1}$ nesse contato abreviado. O resultado foi então comparado com os dados coletados anteriormente.

\subsection{4. - Análise dos dados}

Foi realizada através da estatística descritiva. Os dados coletados foram tabulados em programa de banco de dados, duas vezes, por duas pessoas diferentes. Uma terceira revisão foi feita por uma terceira pessoa. Para facilitar a análise, as variáveis nominais e algumas das variáveis contínuas foram categorizadas, e algumas variáveis não-contínuas foram transformadas em variáveis contínuas. Os critérios estão relacionados na Figura 8. Os detalhes da categorização da "área de atuação médica" encontram-se no Anexo C. Algumas das variáveis foram então submetidas a testes de associação: teste t de Student, teste $\mathrm{t}$ de Fischer, Two-sample $\mathrm{t}$ test, teste do Qui quadrado de Pearson e modelo de regressão logística linear. Todos os resultados foram consideradas com intervalo de confiança de 95\% ou nível de significância de 0,05 . Foi considerada diferença estatisticamente relevante os resultados com $p$ menor que 0,05 .

Utilizamos os seguintes aplicativos de computador no processo de análise de dados:

- FileMaker Pro ver. 6.0.1, FileMaker Inc. - banco de dados

- Microsoft Excel ver. 10.0 e ver. 6.0, Microsoft Corp. - planilha

- Epilnfo ver. 6.0.4 para DOS, CDC/WHO - inferência estatística

- Minitab ver. 10.5, Minitab Inc. - inferência estatística

- Stata ver. 3.0, Stata Inc. - inferência estatística

3.3.4.1. - Análise do grupo que recusou a participação no estudo: Identificamos dois tipos de

De um total de sete perguntas. As duas perguntas eram sorteadas por programa de computador, e a coordenadora não sabia quais eram até a hora de executar o controle de qualidade. Foram utilizadas perguntas sobre sua característica demográfica, tendo em vista a sua condição de permanência. 
recusa, a 'direta, explícita', onde o médico deixa claro que não tem intenção de participar do estudo, e a 'indireta' em que, embora não haja verbalização da recusa, a atitude do indivíduo mostra o seu desinteresse. O meio de identificação da 'recusa indireta' já foi descrito em Grau de insistência.

Analisamos o grupo que recusou a participação no estudo, para comparação com o grupo que respondeu ao questionário. Enviamos nova correspondência solicitando-lhes alguns dados demográficos que pudessem caracterizá-los, a saber: idade, sexo e especialidade. Os dados foram novamente coletados por meio de contato telefônico, pela coordenadora da pesquisa. Demos, então, o mesmo tratamento estatístico descrito no item anterior, para análise e comparação.

Figura 8: Critérios utilizados para categoriação de variáveis contínuas e de variávies nominais.

\begin{tabular}{|c|c|c|}
\hline variável & categorização & critério \\
\hline $\mathrm{n}^{\circ}$ do CRM & faixa de número do CRM & a cada 10.000 números \\
\hline idade & faixa etária & $\begin{array}{l}\text { menos de } 30 \text { anos, mais de } 60 \text { anos e em décadas, } \\
\text { entre } 30 \text { e } 60 \text { anos }\end{array}$ \\
\hline nome da cidade de nascimento & em local de nascimento & $\begin{array}{l}\text { classificação do município em Paulistano, outro } \\
\text { Paulista e Não-paulista }\end{array}$ \\
\hline nome da escola médica da graduação & em tipo de escola & $\begin{array}{l}\text { classificação em escola pública ou privada, } \\
\text { situação em } 2003\end{array}$ \\
\hline nome da escola médica da graduação & em localização da escola & $\begin{array}{l}\text { classificação em Paulistana, outro Paulista e Não- } \\
\text { paulista }\end{array}$ \\
\hline anos de formado & faixa de anos de formado & $\begin{array}{l}\text { em menos de } 5 \text { anos e mais de } 45 \text { anos, e no } \\
\text { intervalo, a cada } 10 \text { anos }\end{array}$ \\
\hline tipos de pós-graduação & $\begin{array}{l}\text { quantidade de pós- } \\
\text { graduação }\end{array}$ & $\begin{array}{l}\text { soma dos tipos de pós-graduação que concluiu; } \\
\text { cada tipo contou uma vez, p. ex. dois para o } \\
\text { médico que fez residência e mestrado e um para } \\
\text { aquele que fez duas residências }\end{array}$ \\
\hline área de atuação médica & $\begin{array}{l}\text { em categorias de } \\
\text { especialidade médica }\end{array}$ & $\begin{array}{l}\text { classificação em grandes carreiras de especialidade } \\
\text { médica: clínica, cirurgia, tocoginecologia, } \\
\text { pediatria e outras especialidades conforme } \\
\text { critério descrito no Anexo C }\end{array}$ \\
\hline $\begin{array}{l}\text { opinião sobre afirmações acerca das } \\
\text { PNCMs }\end{array}$ & em tipo de atitude & $\begin{array}{l}\text { atitude negativa, neutra e atitude positiva, } \\
\text { classificada conforme quantificação descrita em } \\
\text { Identificação da atitude do médico }\end{array}$ \\
\hline $\begin{array}{l}\text { nível de conhecimento referido para alguns } \\
\text { tipos de PNCMs }\end{array}$ & $\begin{array}{l}\text { quantidade de } \\
\text { conhecimento }\end{array}$ & $\begin{array}{l}\text { classificação do conhecimento referido conforme } \\
\text { quantificação descrita em Tratamento do } \\
\text { conhecimento referido }\end{array}$ \\
\hline
\end{tabular}

3.3.4.2. - Identificação da atitude do médico: A atitude de um sujeito perante um determinado assunto pode ser agrupada em quatro tipos: atitude neutra, atitude favorável ou positiva, atitude desfavorável ou negativa e sem opinião. A 'atitude favorável' é aquela em que o sujeito, de uma maneira 
geral, concorda com a prática, consegue conviver bem com ela ou com a situação que a demanda, vê o assunto de maneira positiva. A 'atitude desfavorável' é aquela em que o sujeito, de uma maneira geral, discorda com a prática, sua existência e/ou abordagem o incomoda, vê o assunto de maneira negativa. A 'atitude neutra' é aquela do indivíduo indiferente ao assunto, ou seja, o balanço da sua opinião não pende para nenhum dos lados. Os 'sem opinião' são aqueles que não sabem ou não querem opinar sobre o assunto.

No presente estudo, a identificação da atitude do médico foi feita de duas formas. A primeira, foi a análise univariada das respostas às perguntas referentes à atitude (questões 18 ou 40, 19 e 20 do questionário). A segunda foi a quantificação da atitude utilizando-se das respostas às questões 18 ou 40. Essas questões eram idênticas ${ }^{1}$ e o entrevistado respondia se concordava ou discordava de afirmações referentes à PNCM, através de escala de Likert de cinco pontos. Eram 12 afirmações ao todo, baseadas em estudos publicados, sendo seis positivas e seis negativas, dispostas aleatoriamente ${ }^{2}$. Foi considerada 'resposta positiva' quando o sujeito a) concorda com afirmação positiva ou b) discorda com afirmação negativa. Foi considerada 'resposta negativa' quando o sujeito a) concorda com afirmação negativa ou b) discorda com afirmação positiva. Propositadamente, não levamos em consideração o grau de concordância ou discordância nesta análise, se 'em parte' ou 'bastante' ${ }^{3}$. Para cada afirmativa foi atribuído um valor numérico, +5 para resposta positiva e -5 para resposta negativa. Quando a opinião foi indiferente, foi atribuído o valor $+0,1$, e quando não sabia, a casela foi deixada vazia, o que aconteceu também quando o sujeito não opinou sobre alguma afirmação. A quantidade de afirmações respondidas foram contadas. Obtivemos a quantificação da atitude ${ }^{4}$ através da soma dos valores das atitudes dividida por dez, multiplicada pela quantidade de respostas à afirmação. P.ex., um médico que opinou a todas as afirmações sendo 8 respostas positivas e 4 respostas negativas teve nota 24,0; um outro que opinou a 10 afirmações sendo 8 negativas e 2 positivas tem nota -30,0. Consideramos 'atitude positiva' se a nota tivesse resultado maior que $+12,0$ e 'atitude negativa' se menor que $-12,0$. Entre $-12,0$ e $+12,0$ foi considerada 'atitude neutra'.

E aparecem em local diferente do questionário, pois o fluxo de perguntas, para os que clinicam ou não, era diferente (suprimimos algumas perguntas a respeito da prática clínica para o segundo grupo p.ex. sobre anamnese).

2 É claro que pode haver polêmica com relação à classificação da afirmação. Nesse estudo, partimos do princípio de que uma afirmativa positiva seria aquela em que "exalta a qualidade da prática, é bom saber ou fazer" e a negativa o inverso disso, independentemente da veracidade da afirmação.

3 O que estamos estudando aqui é a atitude e não a intensidade da opinião. Nesse aspecto, essa técnica mostrou-se de interesse já que p.ex., em termos práticos, não existe diferença alguém 'concordar em parte' ou 'discordar em parte' de uma afirmação; mostra sim sua atitude. Para ilustrar, podemos fazer uma analogia com o seguinte: ao ver uma garrafa de bebida na metade, pode se achar que "já foi metade" ou que "ainda tem metade"; não muda a quantidade da bebida mas mostra a atitude do sujeito.

4 Temos consciência de que esse método pode não ser a melhor forma de analisar uma atitude, existem também as análises qualitativas. Foi a maneira para facilitar a inferência estatística, proposta nesta Metodologia. 
3.3.4.3. - Tratamento do conhecimento referido: Foram utilizadas as respostas às perguntas 31 ou 41 do questionário. As PNCM foram selecionadas arbitrariamente a partir de práticas mais comumente vistas em nosso meio e também algumas existentes no exterior, retiradas de literatura existente, para facilitar uma comparação posterior. Foram 13 as PNCM selecionadas: 1. acupuntura; 2. homeopatia; 3. quiropatia, osteopatia; 4. fitoterapia européia; 5. medicina tradicional chinesa; 6. medicina ortomolecular; 7. técnicas de meditação; 8. massoterapia; 9. cura espiritual, reiki; 10. hipnose; 11. florais, aromaterapia; 12. dietas alternativas e 13. terapias em grupo, grupos de auto-ajuda. A definição para cada uma das PNCM está no Anexo B.

Cada uma das práticas da lista foi analisada por partes: 1. no grupo todo, 2. nos que possuem treinamento em alguma modalidade de PNCM, 3. nos que endossam ou prescrevem PNCM e 4. dentre os médicos provedores de PNCM. Para a análise, a resposta foi rearranjada em três faixas de conhecimento: A. 'nenhum conhecimento', B. 'pouco conhecimento' ou 'algum conhecimento' ${ }^{1}$ e C. 'bastante conhecimento'.

\section{4. - ÉTICA DA PESQUISA}

Devemos destacar dois lemas que nortearam a ética deste estudo: a) neutralidade com relação a PNCM e b) a privacidade dos dados colhidos. Além de todos os procedimentos éticos previstos na Resolução no 196/1996 do Conselho Nacional de Saúde, assumimos, desde o início, a posição neutra que se refletiu, inclusive, no desenho do questionário ${ }^{2}$ sempre reiterando que, como pesquisadores, nós "não defendemos, não condenamos, nem recomendamos quaisquer tipo de prática". O presente estudo foi submetido à apreciação da Comissão de Ética para Análise de Projeto de Pesquisa (CAPPesq) do Hospital da Clínicas da Faculdade de Medicina da Universidade de São Paulo, tendo sido aprovado sob o número $789 / 01$.

O cuidado com a ética foi estendido às entrevistadoras e à coordenadora. A equipe recebeu orientação explícita sobre questões de privacidade e de confidencialidade dos dados coletados. Em

\footnotetext{
Para qualquer coisa, 'algum conhecimento' pode ser 'pouco' ou 'muito', depende do referencial de cada indivíduo, mas notamos, no teste-piloto, que "algum" e "pouco" são, de um modo geral, semelhantes na concepção do médico quando existe a opção "bastante". Se o sujeito tem 'algum conhecimento, que pode ser muito', nesse caso ele responde 'bastante'.

2 Notadamente como foram desenhadas as perguntas. Procuramos evitar o uso de termos como "benefício", "malefício", "utilidade", "inutilidade", etc., fazendo com que algumas perguntas tenham ficado indiretas na maneira de abordar a questão. P.ex., ao invés de se perguntar "se o médico notava utilidade terapêutica", perguntamos "se, para o médico, essas práticas tinham alguma ação sobre o resultado terapêutico".
} 
nenhum momento do contato com o médico, elas puderam conversar de outros assuntos se não desse em estudo, fazer quaisquer comentários a respeito da resposta do entrevistado, sempre tendo que se ater a diálogos padronizados. Todo material utilizado pela equipe foi devolvido ao término da coleta de dados. A equipe comprometeu-se com o procedimento ético por escrito, através de "Contrato de Prestação de Serviço".

A parte mais complicada do aspecto operacional do estudo foi a obtenção do consentimento livre e informado dos sujeitos entrevistados, uma vez que a coleta foi feita por telefone, sem contato face-a-face ${ }^{1}$. O consentimento foi colhido verbalmente. Descreveremos, a seguir, a estratégia desenvolvida para atender à peculiaridade da metodologia empregada.

\subsection{1. - Procedimento para obtenção de consentimento informado}

Enviamos via correio, previamente ao primeiro contato telefônico, uma correspondência constituída de: a) carta de apresentação do trabalho, b) esclarecimento da pesquisa, inclusive lista de informações que seriam solicitadas, c) um termo de compromisso onde o pesquisador se compromete formalmente com a privacidade dos dados e a liberdade do entrevistado, e d) meios de contato com o pesquisador $^{2}$. Sempre antes da aplicação do questionário, confirmamos com o médico o recebimento dessa correspondência. Em caso positivo, a entrevistadora confirmava se houve leitura da mesma. Novamente em caso positivo, havia o pedido de confirmação da compreensão de seu conteúdo e seu aceite. Novamente em caso positivo, era feita a leitura de um texto do qual constavam os principais pontos do esclarecimento em relação à pesquisa, do consentimento e dos direitos do entrevistado ${ }^{3}$. Realizada essa etapa, o caso era considerado como consentido e iniciada a aplicação do questionário. Em caso de o médico não ter recebido o documento, o contato telefônico era abortado, o caso reportado à Coordenação que providenciava o reenvio do material. Essa rotina foi realizada quantas vezes fossem necessárias, até cinco vezes.

\footnotetext{
É geralmente quando o sujeito estudado é informado sobre uma pesquisa e assina o termo de consentimento. Para dirimir dúvidas com relação ao assunto ou procedimento ético e para denunciar quaisquer incômodo ou irregularidade que a equipe de entrevistadoras pudesse estar causando. Durante o estudo, disponibilizamos uma linha telefônica direta e exclusiva para este fim.

3 A) direito à confidencialidade das informações fornecidas, B) dirimir quaisquer dúvidas sobre a pesquisa e seu conteúdo, C) liberdade do entrevistado não responder a perguntas que não lhe convierem, D) direito de deixar de participar do estudo e E) ter acesso aos resultados que venham a ser publicados.
} 


\section{5. - TESTES-PILOTO}

Executamos dois testes-piloto para definição da Metodologia até aqui descrita. Um foi feito entre abril e maio de 2002, no Hospital Universitário da Universidade de São Paulo, ${ }^{1}$ e serviu para testar o texto do questionário, em especial, a compreensibilidade das perguntas formuladas. Entrevistamos 19 médicos de diferente especialidades. ${ }^{2}$ Essa fase foi executada face-a-face pelo autor.

O outro foi desenvolvido entre maio e junho de 2002, para testar dois aspectos da metodologia: a) a técnica para encontrar indivíduos através do nome (descrito no item 3.2.2) e b) o método de coleta de dados, em especial a seqüência do envio de correspondência em lotes e contato telefônico para marcação de horário e entrevista. A primeira parte abrangeu 121 indivíduos que retiramos aleatoriamente da lista de médicos do CRM. A segunda parte envolveu 15 médicos, escolhidos nas Listas Amarelas. Essa fase foi executada pela coordenadora, sob supervisão do autor.

Ambas as fases foram empregadas na definição da Metodologia deste trabalho. Além disso, organizamos o 'Manual da Entrevistadora', a partir das experiências do segundo teste piloto.

Com projeto aprovado pela Comissão de Ética em Pesquisa e apoio do Departamento Médico do Hospital. Anotamos que o procedimento de consentimento informado tomou mais tempo que a aplicação do questionário propriamente dito.

2 Administração hospitalar, clínica médica, clínica cirúrgica, ginecologia, pediatria, dermatologia e ortopedia. 


\section{4 - RESULTADOS}

\section{1. - CASUÍStICA}

A metodologia aplicada no presente trabalho permitiu chegar a uma amostra de 537 médicos.

Da amostra inicial de mil indivíduos, encontramos 607 indivíduos e, desses, perdemos 70, por motivos do fator de exclusão, conseguindo 537 indivíduos elegíveis para o estudo (Quadro 1). Pela metodologia utilizada, não foi possível encontrar 39,3\% dos médicos da amostra inicial.

Os médicos que autorizaram a publicação de endereço no site do CRM constituíram 15,2\% da amostra inicial. Outros 45,5\% foram encontrados na lista telefônica de telefone fixo.

A perda total de amostragem foi de $46,3 \%$, a perda por fator de exclusão totalizou $11,5 \%$ (70/607) entre os indivíduos encontrados. Das perdas, a mais importante, 84,9\% (393/463), foi por não ser encontrado na lista do Conselho ou da telefônica.

Quadro 1: Resultado da metodologia empregada em casuística.

\begin{tabular}{|lc|}
\hline descrição & $\mathbf{n}$ \\
\hline amostra inicial & $\mathbf{1 0 0 0}$ a \\
\hline amostra encontrada $(\mathrm{b}+\mathrm{c})=(\mathrm{a}-\mathrm{e})$ & 607 \\
indivíduos encontrados no site do CRM & $152 \mathrm{~b}$ \\
indivíduos encontrados na lista telefônica & $455^{\mathrm{C}}$ \\
\hline perda (e+f+g+h+i) & $\mathbf{4 6 3} \mathrm{d}$ \\
perda por não ser encontrado na lista do CRM e telefônica & 393 e \\
perda por fator de exclusão 'não atende ou atende fax' & $36 \mathrm{f}$ \\
perda por fator de exclusão 'homônimo' & $23 \mathrm{~g}$ \\
perda devido outros fatores de exclusão & $9 \mathrm{~h}$ \\
perda devido extravio do questionário & 2 i \\
\hline amostra estudada (a-d) & $\mathbf{5 3 7}$ \\
\hline
\end{tabular}




\section{2. - DISTRIBUIÇÃO DA POPULAÇÃo E DAS AMOSTRAS ESTUDADAS}

A distribuição do 'número do $\mathrm{CRM}^{\prime}$ da população e das amostras resultou em algumas diferenças, conforme mostramos na Tabela 3. A amostra inicial é semelhante à população de onde foi extraída. Já na amostra, entre a amostra 'perda' e a amostra 'estudada', há diferença importante.

Notamos que houve mais perda em n CRM de número alto, nas faixas acima de 80.001, ou seja, os com menos tempo de inscrição, que são, geralmente, os médicos mais novos. Também observamos mais participação no estudo de médicos com CRM na faixa entre 20.001 e 40.000 $(p<0,001)$.

Tabela 3: Proporção da distribuição do número de inscrição no CRM da população e das amostras estudadas, valores em \%.

\begin{tabular}{lcccc}
\hline & população & & amostra & \\
\cline { 3 - 4 } faixa de número & & inicial & perda $^{(*)}$ & estudada $^{(*)}$ \\
\hline 1 a 10.000 & $\mathrm{n}=37686$ & $\mathrm{n}=1000$ & $\mathrm{n}=463$ & $\mathrm{n}=537$ \\
10.001 a 20.000 & 4,89 & 4,50 & 3,89 & 5,03 \\
20.001 a 30.000 & 9,50 & 9,20 & 7,56 & 10,61 \\
30.001 a 40.000 & 9,46 & 9,00 & 4,10 & 13,22 \\
40.001 a 50.000 & 9,10 & 9,90 & 6,26 & 13,04 \\
50.001 a 60.000 & 9,83 & 11,20 & 10,80 & 1,55 \\
60.001 a 70.000 & 9,89 & 8,70 & 6,26 & 10,80 \\
70.001 a 80.000 & 9,05 & 10,40 & 10,15 & 7,26 \\
80.001 a 90.000 & 8,94 & 8,20 & 9,29 & 6,52 \\
90.001 a 100.000 & 9,64 & 9,50 & 12,96 & 7,45 \\
100.001 e mais & 11,57 & 12,90 & 19,22 & 3,91 \\
\hline
\end{tabular}

(*) t-test $(951)=8,61 \mathrm{p}<0,001$ 


\section{3. - CARACTERÍSTICA DA AMOSTRA ESTUDADA}

Da amostra estudada de 537 indivíduos, 365 aceitaram participar do estudo e 172 recusaramna, perfazendo uma taxa de recusa de 32,0\%. O grupo que recusou participação pode ser dividido em dois tipos: a recusa direta e explícita com 47,1\% (81/172) e a recusa indireta e ou metodológica com $52,9 \%(91 / 172)$.

Ao contatarmos o grupo 'recusa' pela segunda vez, desta vez para colher algumas informações demográficas, 18 indivíduos novamente recusaram explicitamente a participação nessa parte, não nos fornecendo as informações que solicitamos. Também, oito não foram encontrados, o que totalizou 26 (26/172) indivíduos, $15,1 \%$, sem informação.

\subsection{1. - Característica demográfica: sexo.}

A distribuição do sexo em ambos grupos mostrou-se semelhante $(p=0,493)$, com cerca de um terço constituído de mulheres e dois terços de homens (Tabela 4).

Tabela 4: Distribuição do sexo da amostra estudada. Ocorrência, n e \%.

\begin{tabular}{|c|c|c|c|c|c|c|}
\hline \multirow{3}{*}{$\begin{array}{l}\text { sexo } \\
\text { feminino }\end{array}$} & \multicolumn{4}{|c|}{ grupo } & & \\
\hline & \multicolumn{2}{|c|}{ opinou } & \multicolumn{2}{|c|}{ recusou } & \multicolumn{2}{|c|}{ total } \\
\hline & 119 & 32,6 & 51 & 29,7 & 170 & 31,7 \\
\hline masculino & 246 & 67,4 & 121 & 70,3 & 367 & 68,3 \\
\hline total & 365 & 100,0 & 172 & 100,0 & 537 & 100,0 \\
\hline
\end{tabular}

Qui quadrado de Pearson: $p=0,493$

\subsection{2. - Característica demográfica: idade.}

A idade da amostra estudada foi de 45,9 $\pm 11,7$ anos. A média de idade dos que recusaram foi 2,6 anos mais alta $(p=0,026)$. Os indivíduos com mais de 60 anos de idade tenderam a recusar mais e naqueles com menos de 30 anos, a tendência observada foi para menos. Não foi observada diferença estatisticamente significante para a distribuição de idade. (Tabela 5) 
Tabela 5: Característica demográfica da amostra estudada: idade por participação.

\begin{tabular}{|c|c|c|c|c|c|c|}
\hline \multirow[b]{3}{*}{ ocorrência ( n e \%) } & \multicolumn{4}{|c|}{ participação ${ }^{(a)}$} & & \\
\hline & \multicolumn{2}{|c|}{ opinou } & \multicolumn{2}{|c|}{ recusou } & \multicolumn{2}{|c|}{ total } \\
\hline & 365 & 68,0 & 146 & 32,0 & 511 & 100,0 \\
\hline idade em anos: média \pm DP & \multicolumn{2}{|c|}{$45,2 \pm 11,6^{(z)}$} & \multicolumn{2}{|c|}{$47,8 \pm 11,8^{(z)}$} & \multicolumn{2}{|c|}{$45,9 \pm 11,7$} \\
\hline mínimo & \multicolumn{2}{|c|}{25} & \multicolumn{2}{|c|}{27} & \multicolumn{2}{|c|}{25} \\
\hline máximo & \multicolumn{2}{|c|}{79} & \multicolumn{2}{|c|}{87} & \multicolumn{2}{|c|}{87} \\
\hline faixa etária ${ }^{(a)}$ em anos: frequência (n e \%) & 365 & 100,0 & 146 & 100,0 & 511 & 100,0 \\
\hline até 30 & 45 & 12,3 & 7 & 4,8 & 52 & 10,2 \\
\hline 31 a 40 & 83 & 22,7 & 38 & 26,0 & 121 & 23,7 \\
\hline 41 a 50 & 129 & 35,3 & 48 & 32,9 & 177 & 34,6 \\
\hline 51 a 60 & 76 & 20,8 & 36 & 24,7 & 112 & 21,9 \\
\hline 61 e mais & 32 & 8,8 & 17 & 11,6 & 49 & 9,6 \\
\hline
\end{tabular}

(a) Qui quadrado de Pearson: $\mathrm{p}=0,089$

(z) Two-sample t test: $p=0,026$

\subsection{3. - Característica demográfica: área de atuação.}

Dependendo da área de atuação do médico, o padrão de recusa foi diferente. Notamos diferença estatisticamente significante no padrão de sua distribuição dos dois grupos. Os médicos que trabalham em área cirúrgica e tocoginecologia recusaram mais participação; já a recusa foi menor em pediatria e em outras especialidades $(p=0,023)$ (Tabela 6).

Tabela 6: Área de atuação do médico na amostra estudada, n e \%.

\begin{tabular}{|c|c|c|c|c|c|c|}
\hline \multirow{3}{*}{$\begin{array}{l}\text { área de atuação } \\
\text { clínica }\end{array}$} & \multicolumn{4}{|c|}{ grupo } & & \\
\hline & \multicolumn{2}{|c|}{ opinou } & \multicolumn{2}{|c|}{ recusou } & \multicolumn{2}{|c|}{ total } \\
\hline & 134 & 36,9 & 51 & 35,2 & 185 & 36,4 \\
\hline cirúrgica & 59 & 16,3 & 33 & 22,8 & 92 & 18,1 \\
\hline ginecologia e obstetrícia & 43 & 11,9 & 28 & 19,3 & 71 & 14,0 \\
\hline pediatria & 48 & 13,2 & 11 & 7,6 & 59 & 11,6 \\
\hline outras especialidades & 79 & 21,8 & 22 & 15,2 & 101 & 19,9 \\
\hline total & 363 & 100,0 & 145 & 100,0 & 508 & 100,0 \\
\hline
\end{tabular}

Qui quadrado de Pearson: $\mathrm{p}=0,023$ 


\section{4. - CARACTERÍSTICAS DO GRUPO QUE RESPONDEU O QUESTIONÁRIO}

\subsection{1. - Grau de insistência}

O grau de insistência até que conseguíssemos a entrevista, com o médico, foi 3,12 $\pm 1,37$ contatos telefônicos, com mínimo zero e máximo cinco; a mediana encontrada foi três.

\subsection{2. - Características demográficas: faixa etária e local de nascimento}

O local de nascimento da amostra abrangeu 126 municípios de 20 Estados, das cinco regiões brasileiras e 11 países do exterior: 4 sul-americanos, 3 europeus, 2 do Extremo Oriente, 1 do Oriente Médio e 1 norte-americano. O Estado de São Paulo apresentou maior diversidade de municípios. A ocorrência de municípios diferentes por Estado foram: $\mathrm{SP}=63, \mathrm{MG}=14, \mathrm{PR}=5, \mathrm{ES}=5, \mathrm{RS}=4, \mathrm{RJ}=4, \mathrm{BA}=4$, $\mathrm{PB}=4, \mathrm{PE}=3, \mathrm{CE}=3, \mathrm{AL}=3, \mathrm{MA}=3, \mathrm{RN}=2, \mathrm{MS}=2, \mathrm{GO}=2, \mathrm{SE}=1, \mathrm{Pl}=1, \mathrm{SC}=1, \mathrm{DF}=1$ e $\mathrm{PA}=1$.

A Tabela 7 mostra a faixa etária e o local de nascimento categorizado. A média de idade do sexo masculino foi de $47,3 \pm 12,3$ anos, com mediana de 47 e moda de 50, mínima 26 e máxima 79 . No sexo feminino, esses valores foram de 40,9 $\pm 8,5$ anos com mediana de 42, moda de 43, mínima de 25 e máxima de 60. Existe diferença entre os homens e mulheres nessas variáveis: as médicas eram de faixa etária mais baixa $(p<0,001)$, e quando não nascidas no Município de São Paulo, as mulheres tendiam a ser de Estados não-paulistas.

Tabela 7: Características da amostra estudada: dados demográficos por sexo. n e \%.

\begin{tabular}{|c|c|c|c|c|c|c|}
\hline \multirow[t]{2}{*}{ Variáveis } & & & \multicolumn{4}{|c|}{$\operatorname{sexo}^{a}$} \\
\hline & \multicolumn{2}{|c|}{ total } & \multicolumn{2}{|c|}{ masculino } & \multicolumn{2}{|c|}{ feminino } \\
\hline faixa etária ${ }^{a}$ & 365 & & 246 & & 119 & \\
\hline até 30 anos & 45 & 12,3 & 25 & 10,2 & 20 & 16,8 \\
\hline 31 a 40 anos & 83 & 22,7 & 50 & 20,3 & 33 & 27,7 \\
\hline 41 a 50 anos & 129 & 35,3 & 81 & 32,9 & 48 & 40,3 \\
\hline 51 a 60 anos & 76 & 20,8 & 58 & 23,6 & 18 & 15,1 \\
\hline 61 anos e mais & 32 & 8,8 & 32 & 13,0 & $\mathbf{0}$ & 0,0 \\
\hline local de nascimento & 365 & & 246 & & 119 & \\
\hline Município de São Paulo & 172 & 47,1 & 118 & 48,0 & 54 & 45,4 \\
\hline Estado de São Paulo exceto Capital & 94 & 25,8 & 67 & 27,2 & 27 & 22,7 \\
\hline outras localidades não-paulistas & 99 & 27,1 & 61 & 24,8 & 38 & 31,9 \\
\hline
\end{tabular}

${ }^{\mathrm{a}}$ Qui quadrado de Pearson $p<0,001$ 


\subsection{3. - Formação médica: graduação e pós-graduação}

Os médicos que responderam o questionário estudaram em 61 escolas médicas de todo o Brasil e alguns países da América do Sul (vide Anexo D). Após a graduação, a maioria absoluta fez, pelo menos, um curso de pós-graduação dentre as 5 categorias estudadas e em 149 diferentes áreas de conhecimento. O tempo de formado encontrado foi de 19,6 4 10,9 anos, a mediana de 19, mínimo 1 e máximo 52. As mulheres tinham, no geral, menor tempo de formadas, e notamos formação ligeiramente diferente, um pouco mais em escola privada, fora da Capital do Estado de São Paulo (Tabela 8).

Tanto os homens $(98,0 \%)$ como as mulheres $(97,5 \%)$ possuíam cursos de pós-graduação, sensu latu ou sensu strictu, mas notamos maior tendência dos homens seguirem pós-graduação acadêmica. A quantidade de diferentes categorias de pós foi $1,98 \pm 0,98$ com mediana 2. A pósgraduação mais referida foi a 'residência médica' com 84,4\%. Cerca de metade, 53,4\% possuíam algum tipo de 'especialização médica'. Também, 14,2\% dos entrevistados tinham terminado seu doutorado; desses, três quartos eram do sexo masculino (Tabela 9).

Tabela 8: Formação médica por sexo. n e \%.

\begin{tabular}{|c|c|c|c|c|c|c|}
\hline \multirow{3}{*}{$\begin{array}{l}\text { Variáveis } \\
\text { tipo de escola de medicina }\end{array}$} & & & \multicolumn{4}{|c|}{ sexo } \\
\hline & \multicolumn{2}{|c|}{ total } & \multicolumn{2}{|c|}{ masculino } & \multicolumn{2}{|c|}{ feminino } \\
\hline & 365 & & 246 & & 119 & \\
\hline pública & 203 & 55,6 & 143 & 58,1 & 60 & 50,4 \\
\hline privada & 162 & 44,4 & 103 & 41,9 & 59 & 49,6 \\
\hline localização da escola médica & 365 & & 246 & & 119 & \\
\hline Município de São Paulo & 102 & 27,9 & 77 & 31,3 & 25 & 21,0 \\
\hline Estado de São Paulo exceto Capital & 144 & 39,5 & 90 & 36,6 & 54 & 45,4 \\
\hline outras localidades não-paulistas & 119 & 32,6 & 79 & 32,1 & 40 & 33,6 \\
\hline faixa de tempo de formado em medicina & 365 & & 246 & & 119 & \\
\hline até 5 anos & 42 & 11,5 & 25 & 10,2 & 17 & 14,3 \\
\hline 6 a 15 anos & 89 & 24,4 & 51 & 20,7 & 38 & 31,9 \\
\hline 16 a 25 anos & 140 & 38,4 & 92 & 37,4 & 48 & 40,3 \\
\hline 26 a 35 anos & 65 & 17,8 & 49 & 19,9 & 16 & 13,5 \\
\hline 36 anos e mais & 29 & 7,9 & 29 & 11,8 & $\mathbf{0}$ & 0,0 \\
\hline
\end{tabular}


Tabela 9: Pós-graduação médica por sexo, n e \%.

\begin{tabular}{|c|c|c|c|c|c|c|}
\hline \multirow[t]{2}{*}{ Variáveis } & & & \multicolumn{4}{|c|}{ sexo } \\
\hline & \multicolumn{2}{|c|}{ total } & \multicolumn{2}{|c|}{ masculino } & \multicolumn{2}{|c|}{ feminino } \\
\hline quantidade de diferente tipos de pós-graduação & 365 & & 246 & & 119 & \\
\hline 0 & 8 & 2,2 & 5 & 2,0 & 3 & 2,5 \\
\hline 1 & 115 & 31,5 & 74 & 30,1 & 41 & 34,5 \\
\hline 2 & 150 & 41,1 & 96 & 39,0 & 54 & 45,4 \\
\hline 3 & 66 & 18,1 & 53 & 21,6 & 13 & 10,9 \\
\hline 4 & 20 & 5,5 & 12 & 4,9 & 8 & 6,7 \\
\hline 5 & 6 & 1,6 & 6 & 2,4 & $\mathbf{0}$ & 0,0 \\
\hline \multicolumn{7}{|c|}{ tipo de pós-graduação realizado (resposta múltipla; n dos que fizeram o tipo e proporção em relação ao total em \%) $\mathbf{n}=\mathbf{3 6 5}$. } \\
\hline residência médica & 308 & 84,4 & 208 & 84,6 & 100 & 84,0 \\
\hline especialização médica & 195 & 53,4 & 134 & 54,5 & 61 & 51,3 \\
\hline mestrado & 64 & 17,5 & 49 & 19,9 & 15 & 12,6 \\
\hline doutorado & 52 & 14,2 & 39 & 15,9 & 13 & 10,9 \\
\hline outros cursos relevantes para a carreira & 103 & 28,2 & 71 & 28,9 & 32 & 26,9 \\
\hline
\end{tabular}

A maioria absoluta da área de conhecimento buscada na pós-graduação eram, obviamente, da área médica mas foram citadas algumas áreas inusitadas como teologia e filosofia. A Figura 9 mostra os nomes das área de conhecimento da maneira como foram citadas pelo entrevistado. Podemos observar que algumas das áreas podem englobar várias referidas, mas procuramos não interpretar a declaração do médico.

\subsection{4. - Trabalho médico: tipos de atividade e de vínculo empregatício}

Os médicos citaram 80 tipos de atividade médica entre especialidades e sub-especialidades. A cada 3 médicos, mais de um referiu trabalhar na área clínica; a cada 5 médicos, mais de um referiu trabalhar em 'outras especialidades'. Comparando a proporção da área dentro de cada sexo, temos que, tanto o homem como a mulher, tendem a atuar em áreas diferentes no trabalho médico. Enquanto no sexo masculino $61,9 \%$ dos médicos atuam em especialidades clínica e cirúrgica, no sexo feminino, essa proporção cai para 35,3\%. Nas áreas de tocoginecologia, pediatria e outras especialidades, as mulheres somaram $64,7 \%$ e os homens, $38,1 \%$. Em números absolutos, no ambiente de trabalho, na área cirúrgica há muito menos mulheres, 5\% somente. Já na tocoginecologia 46,5\% são mulheres e na pediatria, $60,4 \%$ (Tabela 10). 
Os médicos que responderam o questionário possuíam 1,98 $\pm 0,88$ vínculos de emprego, sendo a mediana 2 com mínimo 1 e máximo 5. Quando perguntados quais eram esses vínculos, em resposta múltipla, os mais freqüentes foram, na ordem: profissional liberal $(79,1 \%)$, emprego público (53,0\%) e assalariado (28,0\%). Essa distribuição mostrou ser semelhante entre os sexos; os homens, entretanto, tendem a ter mais vínculos de emprego. Houve 3 vezes mais empregador do sexo masculino do que do sexo feminino (Tabela 10).

Tabela 10: Atividade médica e tipos de vínculos empregatícios por sexo. $\mathbf{n}$ e \%.

\begin{tabular}{|c|c|c|c|c|c|c|}
\hline \multirow[t]{2}{*}{ Variáveis } & \multirow{2}{*}{\multicolumn{2}{|c|}{ total }} & \multicolumn{4}{|c|}{ sexo } \\
\hline & & & \multicolumn{2}{|c|}{ masculino } & \multicolumn{2}{|c|}{ feminino } \\
\hline área de atuação como médico $(*)$ & \multicolumn{2}{|l|}{363} & \multicolumn{2}{|l|}{244} & \multicolumn{2}{|l|}{119} \\
\hline área clínica & 134 & 36,9 & 95 & 38,9 & 39 & 32,8 \\
\hline área cirúrgica & 59 & 16,3 & 56 & 23,0 & 3 & 2,5 \\
\hline tocoginecologia & 43 & 11,8 & 23 & 9,4 & 20 & 16,8 \\
\hline pediatria & 48 & 13,2 & 19 & 7,8 & 29 & 24,4 \\
\hline outras especialidades & 79 & 21,8 & 51 & 20,9 & 28 & 23,5 \\
\hline \multicolumn{7}{|c|}{ tipos de vínculos de emprego que o médico possui (resposta múltipla; n e proporção em relação ao total em \%) n=364 } \\
\hline serviço público & 193 & 53,0 & 132 & 53,9 & 61 & 51,3 \\
\hline profissional liberal & 288 & 79,1 & 199 & 81,2 & 89 & 74,8 \\
\hline assalariado & 102 & 28,0 & 70 & 28,6 & 32 & 26,9 \\
\hline empregador & 45 & 12,4 & 39 & 15,9 & 6 & 5,0 \\
\hline cooperado & 54 & 14,8 & 37 & 15,1 & 17 & 14,3 \\
\hline outros vínculos & 39 & 10,7 & 25 & 10,2 & 14 & 11,8 \\
\hline
\end{tabular}

(*) categorizado conforme critérios descritos no Anexo C 
Figura 9: Nome da área de conhecimento estudada na pós-graduação.

\begin{tabular}{|c|c|c|}
\hline acupuntura & gastropediatria & neurolingüística \\
\hline administração de empresas & genética médica & neurologia \\
\hline administração de negócios & geriatria & neuropediatria \\
\hline administração hospitalar & gestão de saúde & nutrologia \\
\hline administração pública & ginecologia & obstetrícia \\
\hline alergia & ginecologia e obstetrícia & oftalmologia \\
\hline anatomia patológica & hematologia & oncologia clínica \\
\hline anestesiologia & histereoscopia & ortopedia \\
\hline cardiologia & homeopatia & osteoporose \\
\hline cirurgia cardíaca & imagenologia & osteosíntese \\
\hline cirurgia cardiovascular & imunologia & otorrinolaringologia \\
\hline cirurgia craneofacial & imunologia pediátrica & otorrinolaringologia pediátrica \\
\hline cirurgia da cabeça e pescoço & infecção hospitalar & patologia \\
\hline cirurgia da coluna & infectologia & patologia clínica \\
\hline cirurgia da mão & infectologia pediátrica & patologia gastrointestinal \\
\hline cirurgia do aparelho digestivo & infertilidade conjugal & patologia hepática \\
\hline cirurgia do joelho & intradermoterapia & patologia humana \\
\hline cirurgia do pé & laparoscopia & pediatria \\
\hline cirurgia do quadril & lente de contato & pediatria genética \\
\hline cirurgia geral & lipoescultura & pneumologia \\
\hline cirurgia oncológica & mamografia & pneumonologia geriátrica \\
\hline cirurgia orbitopalpebral & mastologia & pneumonologia pediátrica \\
\hline cirurgia pediátrica & medicina aeroespacial & proctologia \\
\hline cirurgia plástica & medicina antroposófica & propedêutica \\
\hline cirurgia torácica & medicina comunitária & prótese de quadril \\
\hline cirurgia vascular & medicina de família & pseudoartrose \\
\hline clínica cirurgica & medicina do trabalho & psicanálise \\
\hline clínica geral & medicina do tráfego & psicobiologia \\
\hline clínica médica & medicina esportiva & psicologia \\
\hline colposcopia & medicina estética & psicoterapia \\
\hline densitometria óssea & medicina farmacêutica & psiquiatria \\
\hline dermatologia & medicina fetal & quiropatia \\
\hline dor & medicina intensiva & radiologia \\
\hline ecocardiologia & medicina legal & radiologia clínica \\
\hline economia & medicina molecular & reprodução humana \\
\hline emergência & medicina nuclear & reumatologia \\
\hline emergência pediátrica & medicina ortomolecular & saúde da criança e do adolecente \\
\hline endocrinologia & medicina preventiva & saúde mental \\
\hline endoscopia & medicina psicossomática & saúde pública \\
\hline endoscopia digestiva & medicina social & sexologia \\
\hline epidemiologia & medicina tradicional chinesa & teologia \\
\hline epidemiologia clínica & medicina tropical & terapia intensiva pediátrica \\
\hline epidemiologia de câncer & mesoterapia & tomografia \\
\hline filosofia & metabolismo & toxicologia \\
\hline fisiatria & microcirurgia & transplante de orgãos \\
\hline fisiologia & morfologia & traumatologia \\
\hline fisiologia do exercício & nefrologia & ultrassonografia \\
\hline fitoterapia & neonatologia & urologia \\
\hline fitoterapia chinesa & neuroaudiologia & videolaparoscopia \\
\hline gastroenterologia & neurocirurgia & \\
\hline
\end{tabular}




\subsection{5. - Trabalho médico: principal vínculo empregatício, tipo e local}

O principal trabalho mais frequentemente citado pelos médicos foi profissional liberal $(47,4 \%)$; em relação ao vínculo, atividade clínica (81,0\%); em relação ao local de trabalho, atuação em clínicas ou consultórios (43,9\%). Em segundo lugar, encontramos servidor público (27,8\%), atividade administrativa $(9,6 \%)$ e atuação em ambiente hospitalar $(37,4 \%)$. Não existe grande diferença entre os sexos nessa distribuição. Comparado com a resposta múltipla de tipos de vínculos vista no item anterior, podemos deduzir que uma parte considerável dos médicos trabalha como profissional liberal mas possui outro vínculo, possivelmente na metade dos casos e esse deve ser algum emprego público. Notamos que um pouco mais de médicos trabalham em clínica ou consultório do que em ambiente hospitalar; as mulheres são cerca de $20 \%$ mais freqüentes nessa última situação.

Para o quesito "principal", o critério de importância foi deixado livremente para o entrevistado escolher; geralmente, a escolha deu-se: a) em termos financeiros; b) em termos de carreira; c) em termos de tempo dedicado, d) em termos de estima. (Tabela 11)

Tabela 11: Principal trabalho médico por sexo. $\mathrm{n}$ e \%.

\begin{tabular}{|c|c|c|c|c|c|c|}
\hline \multirow[t]{2}{*}{ Variáveis } & & & \multicolumn{4}{|c|}{ sexo } \\
\hline & \multicolumn{2}{|c|}{ total } & \multicolumn{2}{|c|}{ masculino } & \multicolumn{2}{|c|}{ feminino } \\
\hline vínculo empregatício principal & 363 & & 245 & & 118 & \\
\hline serviço público & 101 & 27,8 & 64 & 26,1 & 37 & 31,4 \\
\hline profissional liberal & 172 & 47,4 & 116 & 47,3 & 56 & 47,4 \\
\hline assalariado & 42 & 11,6 & 30 & 12,2 & 12 & 10,2 \\
\hline empregador & 21 & 5,8 & 20 & 8,2 & 1 & 0,8 \\
\hline cooperado & 7 & 1,9 & 5 & 2,1 & 2 & 1,7 \\
\hline outros vínculos & 20 & 5,5 & 10 & 4,1 & 10 & 8,5 \\
\hline descrição do principal vínculo empregatício & 363 & & 245 & & 118 & \\
\hline atividade clínica & 294 & 81,0 & 188 & 76,7 & 106 & 89,8 \\
\hline docência e pesquisa & 23 & 6,3 & 19 & 7,8 & 4 & 3,4 \\
\hline atividade administrativa & 35 & 9,6 & 29 & 11,8 & 6 & 5,1 \\
\hline outro tipo de atividade & 11 & 3,0 & 9 & 3,7 & 2 & 1,7 \\
\hline local do principal vínculo empregatício & 364 & & 245 & & 119 & \\
\hline clínica, consultório & 160 & 43,9 & 107 & 43,7 & 53 & 44,5 \\
\hline ambiente hospitalar & 136 & 37,4 & 86 & 35,1 & 50 & 42,0 \\
\hline ambos & 36 & 9,9 & 27 & 11,0 & 9 & 7,6 \\
\hline outros & 32 & 8,8 & 25 & 10,2 & 7 & 5,9 \\
\hline
\end{tabular}




\subsection{6. - Experiência com PNCM: impressão do contato e percepção de demanda}

A PNCM é mais prevalente de maneira privada na vida dos médicos. Os médicos referiram ter tido mais contato particular do que contato profissional com PNCM; 62,4\% (227/364) tiveram contato particular e 52,2\% (190/364) tiveram contato profissional. A mesma ordem é observada entre os que não tiveram contato; $1,8 \%(4 / 227)$ não tiveram contato particular e 5,8\% (11/190) não tiveram contato profissional. (Tabela 12)

A impressão com PNCM quando esse contato houve, mostrou distribuição semelhante nesses dois tipos de contato, com pelo menos dois em três relatando boa impressão. Não foi verificada diferença entre os sexos. (Tabela 12)

A maioria absoluta dos médicos percebe demanda por PNCM. Quando perguntados sobre a demanda por essa modalidade de prática na sociedade, em geral, 87,6\% disseram perceber que tal procura existe. Nesse caso, também, não houve diferença de resposta entre os sexos. (Tabela 12)

Tabela 12: Impressão com PNCM por sexo. $n$ e \%.

\begin{tabular}{|c|c|c|c|c|c|c|}
\hline \multirow[t]{2}{*}{ Variáveis } & & & \multicolumn{4}{|c|}{ sexo } \\
\hline & \multicolumn{2}{|c|}{ total } & \multicolumn{2}{|c|}{ masculino } & \multicolumn{2}{|c|}{ feminino } \\
\hline impressão do contato profissional com PNCM & 190 & & 115 & & 75 & \\
\hline boa & 130 & 68,4 & 75 & 65,2 & 55 & 73,3 \\
\hline indiferente & 29 & 15,3 & 20 & 17,4 & 9 & 12,0 \\
\hline ruim & 20 & 10,5 & 11 & 9,6 & 9 & 12,0 \\
\hline não sabe & 11 & 5,8 & 9 & 7,8 & 2 & 2,7 \\
\hline não teve contato & 11 & 5,8 & 9 & 7,8 & 2 & 2,7 \\
\hline impressão do contato privado com PNCM & 227 & & 145 & & 82 & \\
\hline boa & 169 & 74,4 & 104 & 71,7 & 65 & 79,3 \\
\hline indiferente & 33 & 14,5 & 24 & 16,5 & 9 & 11,0 \\
\hline ruim & 21 & 9,3 & 14 & 9,7 & 7 & 8,5 \\
\hline não sabe & 4 & 1,8 & 3 & 2,1 & 1 & 1,2 \\
\hline não teve contato & 4 & 1,8 & 3 & 2,1 & 1 & 1,2 \\
\hline percepção de demanda por PNCM & 364 & & 246 & & 118 & \\
\hline não & 29 & 8,0 & 21 & 8,5 & 8 & 6,8 \\
\hline $\operatorname{sim}$ & 319 & 87,6 & 214 & 87,0 & 105 & 89,0 \\
\hline não sabe & 16 & 4,4 & 11 & 4,5 & 5 & 4,2 \\
\hline
\end{tabular}




\subsection{7. - Opinião sobre PNCM: são boas ou ruins?}

A Tabela 13 organiza as opiniões dos médicos em relação às PNCM: são boas ou ruins, para o paciente, para o médico e para o resultado terapêutico. Quando perguntado ao médico se PNCM influencia o resultado terapêutico, para o paciente, um número considerável (99/331) recusou-se a responder a essa pergunta. Dos que responderam, uma grande parte, 76,6\% referem que, de uma forma ou outra, PNCM tem influência no resultado para o paciente. Desses, de cada 5 médicos, 4 acham que tal influência é positiva. Quando perguntados sobre a influência no trabalho do médico, 58,8\% notam que PNCM altera o trabalho; desses, 72,8\% acham que essa alteração é positiva. Quando perguntados se PNCM tem ação terapêutica, 61,9\% notam que PNCM tem ação; desses 86,0\% acham que essa influência é positiva. A atitude da resposta vai mudando conforme a questão, a recusa vai diminuindo (29,9\%, 5,4\% e 1,9\% respectiva-mente) mas, por outro lado, a dúvida ("não sabe") vai aumentando $(5,3 \%, 19,2 \%$ e $23,8 \%)$.

Não existe diferença estatística nessa distribuição entre os sexos, entretanto as mulheres tenderam a fazer uma avaliação mais positiva do quadro ou não souberam avaliar.

Tabela 13: PNCM são boas ou ruins? Para paciente, médico e resultado, por sexo. n e \%.

\begin{tabular}{|c|c|c|c|c|c|c|}
\hline \multirow[t]{2}{*}{ Variáveis } & & & \multicolumn{4}{|c|}{ sexo } \\
\hline & \multicolumn{2}{|c|}{ total } & \multicolumn{2}{|c|}{ masculino } & \multicolumn{2}{|c|}{ feminino } \\
\hline PNCM influencia resultado terapêutico para o paciente & \multicolumn{2}{|c|}{265 (de 331) } & \multicolumn{2}{|l|}{179} & \multicolumn{2}{|l|}{86} \\
\hline não & 48 & 18,1 & 34 & 19,0 & 14 & 16,3 \\
\hline sim, positivamente & 163 & 61,5 & 104 & 58,1 & 59 & 68,6 \\
\hline sim, negativamente & 40 & 15,1 & 31 & 17,3 & 9 & 10,5 \\
\hline não sabe & 14 & 5,3 & 10 & 5,6 & 4 & 4,6 \\
\hline PNCM altera o trabalho do médico & \multicolumn{2}{|c|}{313 (de 331) } & \multicolumn{2}{|l|}{206} & \multicolumn{2}{|l|}{107} \\
\hline não & 69 & 22,0 & 50 & 24,3 & 19 & 17,8 \\
\hline sim, positivamente & 134 & 42,8 & 84 & 40,8 & 50 & 46,7 \\
\hline sim, negativamente & 50 & 16,0 & 36 & 17,5 & 14 & 13,1 \\
\hline não sabe & 60 & 19,2 & 36 & 17,5 & 24 & 22,4 \\
\hline PNCM age sobre o resultado terapêutico & \multicolumn{2}{|c|}{357 (de 364) } & \multicolumn{2}{|l|}{241} & \multicolumn{2}{|l|}{116} \\
\hline não & 61 & 17,1 & 43 & 17,8 & 18 & 15,5 \\
\hline sim, positivamente & 190 & 53,2 & 130 & 54,0 & 60 & 51,7 \\
\hline sim, negativamente & 21 & 5,9 & 16 & 6,6 & 5 & 4,3 \\
\hline sim, positivamente e negativamente & 10 & 2,8 & 7 & 2,9 & 3 & 2,6 \\
\hline não sabe & 85 & 23,8 & 52 & 21,6 & 33 & 28,5 \\
\hline
\end{tabular}




\subsection{8. - Experiência com PNCM: treinamento, anamnese, endosso e prática}

A Tabela 14 resume a experiência do médico com PNCM. Um quarto dos entrevistados $(26,9 \%)$ referiram possuir treinamento em uma ou mais PNCM. Proporcionalmente, o treinamento foi maior entre as mulheres. Dos que tiveram treinamento, a maioria concluiu esse treinamento e em mais de dois terços dos casos, o treinamento foi realizado em ambiente acadêmico. Dos médicos que clinicam, que têm contato com paciente, $41 \%$ não fazem perguntas sobre o uso de PNCM, na anamnese, 28\% o fazem sempre. Também, entre os que clinicam, pouco mais da metade, 52,9\%, endossam, indicam ou prescrevem, pelo menos, uma modalidade de PNCM, tendência maior entre as mulheres. Desse grupo, um quarto, 25,1\%, são provedores de PNCM, novamente proporcionalmente maior entre as mulheres. Dentre os médicos que clinicam, os provedores totalizaram 13,3\%. (Idade dos provedores: 45,4ะ8,6 anos Moda 52 Mediana 45 Min 27 Máx 67.

Tabela 14: Experiência do médico com PNCM: treinamento, anamnese, endosso e provedor, n e \%.

\begin{tabular}{|c|c|c|c|c|c|c|}
\hline \multirow[t]{2}{*}{ Variáveis } & \multirow{2}{*}{\multicolumn{2}{|c|}{ total }} & \multicolumn{4}{|c|}{ sexo } \\
\hline & & & \multicolumn{2}{|c|}{ masculino } & \multicolumn{2}{|c|}{ feminino } \\
\hline possui treinamento em PNCM & 331 & & 219 & & 112 & \\
\hline não & 242 & 73,1 & 170 & 77,6 & 72 & 64,3 \\
\hline $\operatorname{sim}$ & 89 & 26,9 & 49 & 22,4 & 40 & 35,7 \\
\hline concluiu o treinamento $(n=89)$ & 67 & 75,3 & 34 & 69,4 & 33 & 82,5 \\
\hline treinamento em ambiente acadêmico $(n=88)$ & 60 & 68,2 & 34 & 69,4 & 26 & 66,7 \\
\hline faz perguntas sobre uso de PNCM na anamnese & 322 & & 214 & & 108 & \\
\hline não & 132 & 41,0 & 86 & 40,2 & 46 & 42,6 \\
\hline sim, depende do caso & 100 & 31,0 & 71 & 33,2 & 29 & 26,9 \\
\hline sim, sempre & 90 & 28,0 & 57 & 26,6 & 33 & 30,6 \\
\hline endossa, indica ou prescreve PNCM & 323 & & 213 & & 110 & \\
\hline não & 152 & 47,1 & 111 & 52,1 & 41 & 37,3 \\
\hline $\operatorname{sim}$ & 171 & 52,9 & 102 & 47,9 & 69 & 62,7 \\
\hline $\begin{array}{l}\text { provedor de PNCM que prescreve } \\
\qquad(\mathrm{n}=171)\end{array}$ & 43 & $(\mathbf{a}),(\mathbf{b}),(\mathbf{c})$ & 21 & - & 22 & - \\
\hline $\begin{array}{llll}\text { (a) } & 25,1 \% & (43 / 171) & \text { proporção para o total dos médic } \\
\text { (b) } & 13,3 \% & (43 / 323) & \text { proporção para o total dos médic } \\
\text { (c) } & 11,8 \% & (43 / 364) & \text { proporção para o total dos médic }\end{array}$ & $\begin{array}{l}\text { ue pres } \\
\text { ue clin }\end{array}$ & $\begin{array}{l}\text { revem } \\
\text { am } \\
\text { nderam ao } q\end{array}$ & ionári & & & \\
\hline
\end{tabular}




\subsection{9. - Experiência com PNCM: conhecimento referido}

Os próximos quatro gráficos mostram a distribuição do conhecimento referido para treze modalidades de PNCM selecionadas, no trabalho, dentre os seguintes grupos:

1. todos que responderam o questionário;

2. médicos que possuem treinamento em alguma modalidade de PNCM;

3. médicos que endossam ou prescrevem, pelo menos, uma modalidade de PNCM e

4. médicos provedores de, pelo menos, uma modalidade de PNCM.

As respostas 'pouco conhecimento' e 'algum conhecimento' foram agrupadas. Para facilitar a redação e leitura no gráfico, abreviamos a denominação das modalidades, mas sempre estamos nos referindo ao grupo de modalidade definido no Anexo B. 
O Gráfico 1 mostra a distribuição do conhecimento entre todos que responderam o questionário. A grande maioria dos médicos referiu ter pouco/algum ou nenhum conhecimento nas modalidades estudadas de PNCM. Somente 'acupuntura', 'homeopatia' e 'terapias em grupo' foram as práticas em que mais de dez porcento dos médicos referiram bastante conhecimento (respectivamente, $15,1 \%, 12,9 \%$ e $12,7 \%)$.

As cinco PNCM com maior ocorrência de 'nenhum conhecimento' foram, na ordem: 1. cura espiritual (70,8\%), 2. quiropatia $(65,4 \%), 3$. medicina chinesa $(62,4 \%)$, 4. hipnose $(61,0 \%)$ e 5 . florais (60,5\%). As cinco PNCM com maior ocorrência de 'pouco ou algum conhecimento' foram, na ordem: 1. homeopatia $(66,5 \%), 2$. acupuntura $(65,1 \%)$, 3. terapia em grupo $(56,9 \%), 4$. dietas alternativas $(52,5 \%)$ e 5 . massagem $(52,2 \%)$.

Gráfico 1. Distribuição do conhecimento referido de todos que responderam o questionário. $\mathrm{N}=364$. Valores em \%.

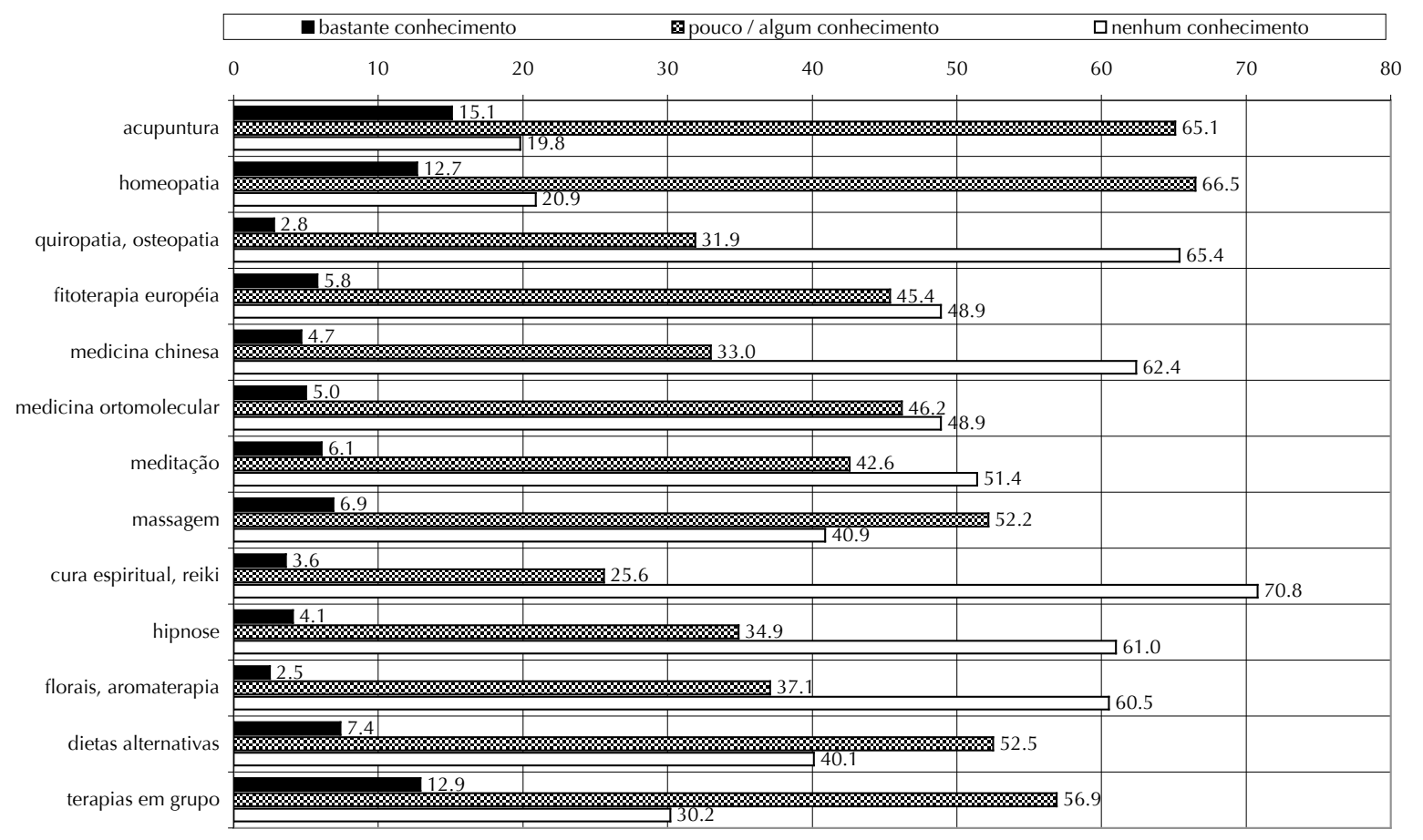

O Gráfico 2 mostra a distribuição entre os médicos que possuem treinamento em alguma modalidade de PNCM. Nesse grupo, também, a grande maioria referiu ter nenhum, pouco ou algum conhecimento nas modalidades de PNCM estudadas. 'Acupuntura' e 'homeopatia' foram as duas modalidades em relação às quais mais médicos referiram 'bastante conhecimento', 27,8\% e 23,3\% 
respectivamente.

As cinco PNCM com maior ocorrência de 'nenhum conhecimento' foram, na ordem: 1. hipnose $(65,6 \%)$, 2. cura espiritual (60,0\%), 3. quiropatia (56,7\%), 4. medicina ortomolecular $(53,3 \%)$ e florais (53,3\%). As cinco PNCM com maior ocorrência de 'pouco ou algum conhecimento' foram, na ordem: 1. homeopatia $(60.0 \%)$ e fitoterapia européia $(60,0 \%)$, 3. acupuntura (54,5\%), 4. dietas alternativas $(51,1 \%)$ e 5 . massagem $(50,0 \%)$.

Comparando-se este grupo com o anterior que mostra todos os médicos, neste sobressai a medicina chinesa e a fitoterapia européia, com mais indivíduos referindo maior conhecimento. No caso da 'medicina chinesa', no grupo anterior era um dos PNCM que mais ocorrência teve para 'nenhum conhecimento', e entre os que tem treinamento, é o terceiro mais freqüente entre os que referiram ter 'bastante conhecimento'. O mesmo fenômeno não se observa com 'fitoterapéia européia' pois 45,4\% de todos os médicos possuem pouco ou algum conhecimento.

Gráfico 2. Distribuição do conhecimento referido entre os que têm treinamento em PNCM. $\mathrm{N}=90$. Valores em \%.

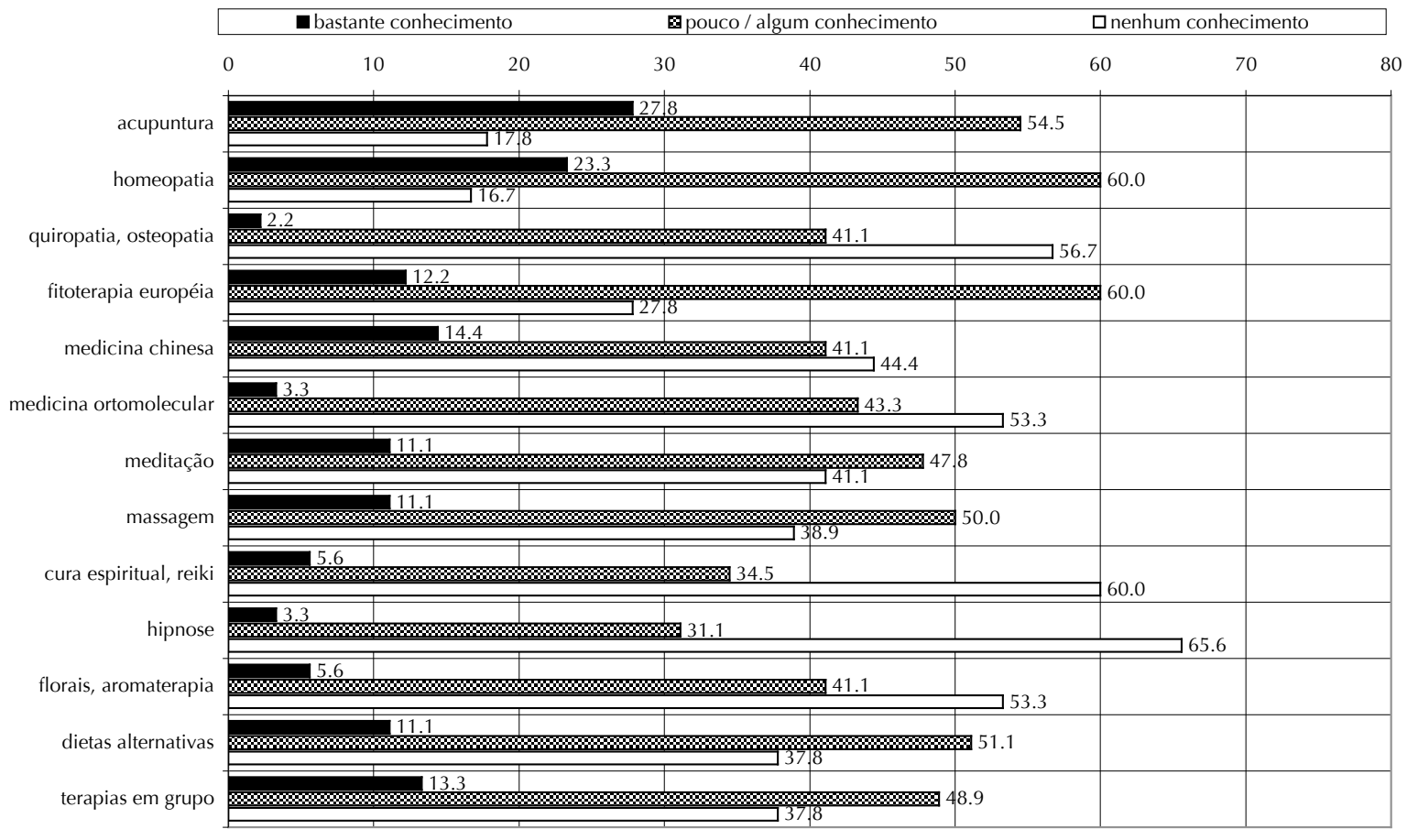

O Gráfico 3 mostra a distribuição do conhecimento entre os médicos que endossam ou 
prescrevem, pelo menos, uma modalidade de PNCM. Neste grupo, novamente, a grande maioria dos médicos referiu ter nenhum ou pouco ou algum conhecimento nas várias modalidades de PNCM em estudo. As práticas que tiveram mais de dez porcento de 'bastante conhecimento' foram, na ordem: 1 . acupuntura $(22,1 \%)$, 2. homeopatia $(17,4 \%), 3$. terapias em grupo $(14,5 \%)$ e 4 . massagem $(11,1 \%)$.

As cinco PNCM com maior ocorrência de 'nenhum conhecimento' foram, na ordem: 1. hipnose $(65,5 \%)$, 2. cura espiritual $(61,6 \%)$, 3. quiropatia $(57,6 \%)$, 4. florais $(52,9 \%)$ e 5 . medicina chinesa (51,7\%). As cinco PNCM com maior ocorrência de 'pouco ou algum conhecimento' foram, na ordem: 1. acupuntura $(64,0 \%)$, 2. homeopatia $(63,0 \%)$, 3. terapias em grupo $(56,4 \%), 4$. dietas alternativas $(55,9 \%)$ e 5 . massagem $(52,3 \%)$.

A distribuição do conhecimento referido nesse grupo é bastante parecida com aquela vista no grupo de todos os médicos (Gráfico 1).

Gráfico 3. Distribuição do conhecimento referido entre os que prescrevem ou endossam PNCM. N= 172. Valores em \%.

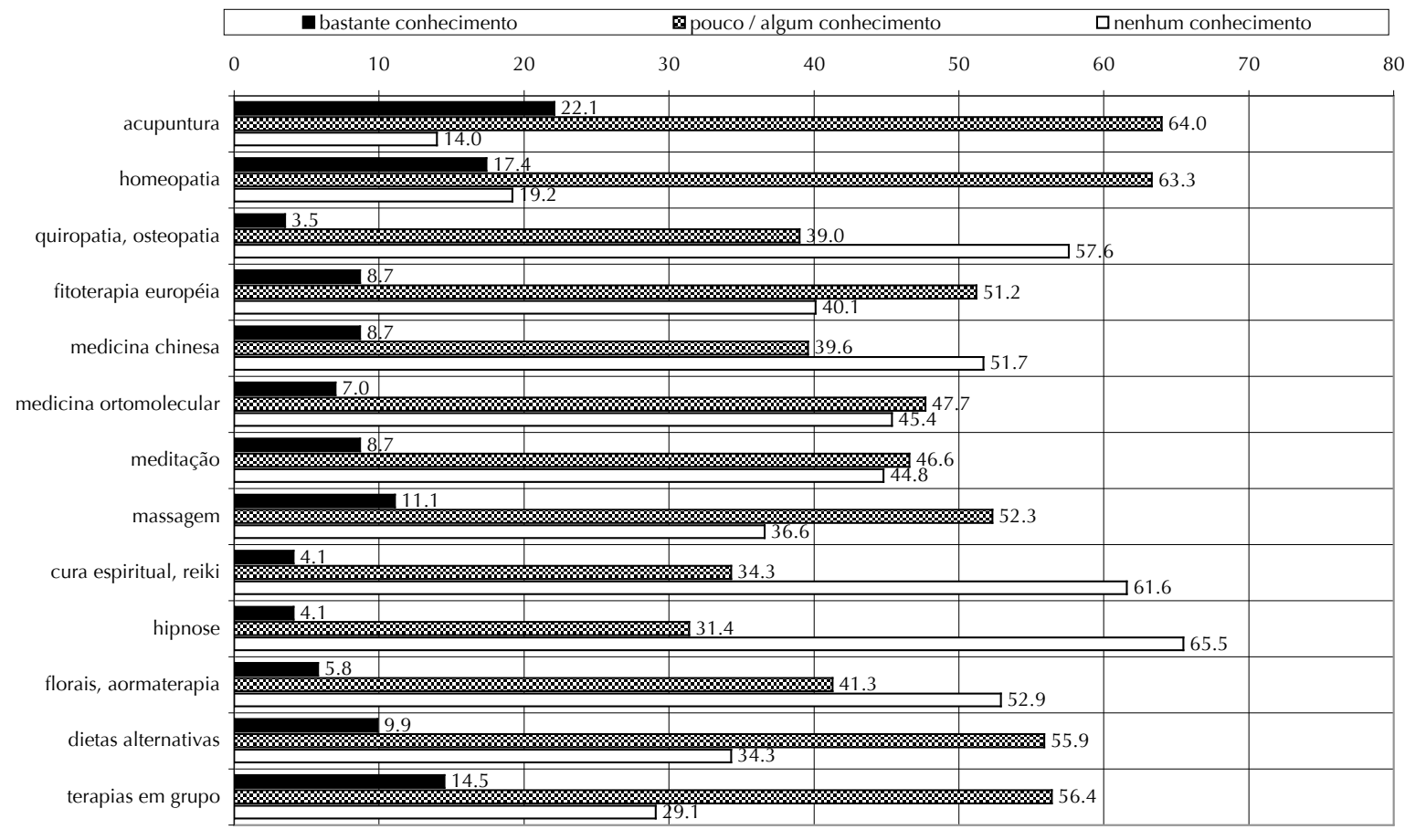

O Gráfico 4 mostra a distribuição do conhecimento referido entre os médicos provedores de PNCM. Aqui, notamos um incremento na ocorrência de 'bastante conhecimento' quando comparadas 
as distribuições com a dos três grupos anteriores. Também podemos deduzir que a modalidade de PNCM com 'bastante conhecimento' referida é, provavelmente, aquela praticada pelo médico.

Embora nesse grupo também a maior ocorrência seja de nenhum, pouco ou algum conhecimento nas PNCM estudadas, chama a atenção a inversão da quantidade de médicos que referem bastante conhecimento em acupuntura e homeopatia. Enquanto a primeira foi mais referida como 'bastante' nos três grupos anteriores, a segunda foi a mais referida como 'bastante' entre os médicos provedores (34,1\% a $29,6 \%)$. Novamente, a medicina chinesa aparece em terceiro lugar na ocorrência de bastante conhecimento $(22,7 \%)$, seguida de fitoterapia européia $(13,6 \%)$.

As cinco PNCM com maior ocorrência de 'nenhum conhecimento', nesse grupo, foram, na ordem: 1. cura espiritural e hipnose (ambas com $61,4 \%)$, 3. quiropatia $(56,8 \%)$, 4. florais $(47,7 \%)$ e 5 . medicina chinesa $(45,5 \%)$. As cinco PNCM com maior ocorrência de 'pouco ou algum conhecimento' foram, na ordem: 1. fitoterapia européia (70,5\%), 2. dietas alternativas (56,9\%), 3. meditação $(54,6 \%), 4$. medicina ortomolecular (52,3\%) e 5. homeopatia e terapias em grupo (ambas com 50,0\%).

Gráfico 4. Distribuição do conhecimento referido entre os que são provedores de PNCM. N= 44 . Valores em \%.

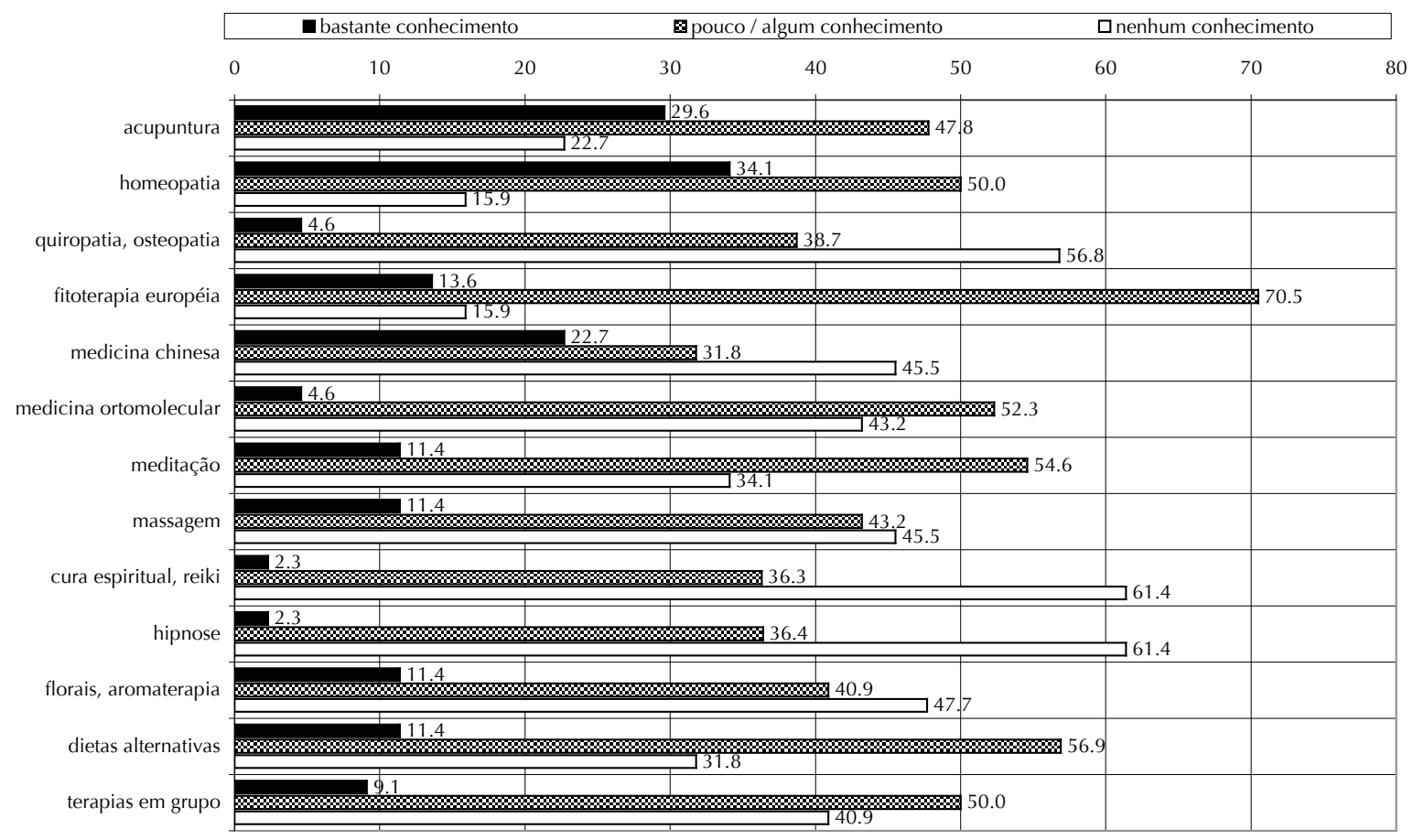




\subsubsection{0. - Atitude do médico: considera-se generalista ou especialista?}

Quando perguntado aos médicos que clinicam "se se consideravam generalista ou especialista, na maioria do tempo da prática clínica", o grupo pendeu ligeiramente para especialista; $55,1 \%$ consideraram-se especialistas e $42,8 \%$ consideraram-se generalistas (Tabela 15).

Tabela 15: Generalista ou especialista? Por sexo, n e \%.

\begin{tabular}{crrrrrr}
\hline Variáveis & \multicolumn{2}{c}{ total } & & \multicolumn{3}{c}{ sexo } \\
\cline { 5 - 7 } & & & masculino & \multicolumn{2}{c}{ feminino } \\
\hline como médico, considera-se na maior parte do tempo & $\mathbf{3 3 2}$ & & $\mathbf{2 1 9}$ & & $\mathbf{1 1 3}$ \\
\hline generalista & $\mathbf{1 4 2}$ & 42,8 & $\mathbf{9 2}$ & 42,0 & $\mathbf{5 0}$ & 44,2 \\
especialista & $\mathbf{1 8 3}$ & 55,1 & $\mathbf{1 2 2}$ & 55,7 & $\mathbf{6 1}$ & 54,0 \\
não sabe & $\mathbf{7}$ & 2,1 & $\mathbf{5}$ & 2,3 & $\mathbf{2}$ & 1,8 \\
\hline
\end{tabular}

\subsubsection{1. - Atitude do médico frente a PNCM, em geral.}

Metade dos médicos estudados mostraram ter atitude positiva com relação a PNCM, de uma maneira geral; já a outra metade mostrou atitude não-positiva.

A Tabela 16 mostra a distribuição da atitude do médico sobre PNCM. A classificação da atitude foi feita conforme metodologia já descrita. Dentre os que mostraram atitude não-positiva, de cada 5 médicos, 2 tinham atitude negativa e 3 atitude neutra. Notamos, entre as mulheres, tendência de ter atitude menos negativa com PNCM.

Tabela 16: Atitude do médico frente a PNCM. Por sexo, n e \%.

\begin{tabular}{crrrrrr}
\hline Variáveis & \multicolumn{2}{c}{ total } & \multicolumn{3}{c}{ sexo } \\
\cline { 5 - 8 } & \multicolumn{2}{c}{ masculino } & & feminino \\
\hline atitude frente a PNCM & $\mathbf{3 6 4}$ & & $\mathbf{2 4 6}$ & & $\mathbf{1 1 8}$ \\
\hline negativa & $\mathbf{7 1}$ & 19,5 & $\mathbf{5 3}$ & 21,5 & $\mathbf{1 8}$ & 15,3 \\
neutra & $\mathbf{1 0 9}$ & 29,9 & $\mathbf{7 3}$ & 29,7 & $\mathbf{3 6}$ & 30,5 \\
positiva & $\mathbf{1 8 4}$ & 50,6 & $\mathbf{1 2 0}$ & 48,8 & $\mathbf{6 4}$ & 54,2 \\
\hline
\end{tabular}




\subsubsection{2. - Atitude do médico: familiaridades com PNCM, absoluta e relativa}

A Tabela 17 mostra como o médico se auto-avalia quanto à familiaridade com o assunto estudado. A primeira parte mostra a familiaridade absoluta com o assunto e a segunda, a familiaridade relativa, como o médico se compara com outros colegas.

Setenta e dois porcento dos médicos consideram ter alguma ou pouca familiaridade com PNCM, 16,0\% nenhuma e 9,7\% muita familiaridade. Já quando perguntados como seria essa familiaridade quando comparados com colegas médicos, a resposta mais ouvida foi ser igual $(42,7 \%)$, seguida de melhor $(24,9 \%)$, não sabe $(20,6 \%)$ e pior $(11,8 \%)$. A auto-avaliação, tanto absoluta como relativa, melhora no sexo feminino. O resultado também mostra que o médico não foi incoerente na resposta; a maioria entende ter pouca ou alguma familiaridade com PNCM e essa condição é igual ou melhor que a dos colegas.

Tabela 17: Familiaridades absoluta e relativa a PNCM. Por sexo, n e \%.

\begin{tabular}{|c|c|c|c|c|c|c|}
\hline \multirow[t]{2}{*}{ Variáveis } & & & \multicolumn{4}{|c|}{ sexo } \\
\hline & \multicolumn{2}{|c|}{ total } & \multicolumn{2}{|c|}{ masculino } & \multicolumn{2}{|c|}{ feminino } \\
\hline familiaridade absoluta com PNCM & 329 & & 219 & & 110 & \\
\hline muita & 32 & 9,7 & 16 & 7,3 & 16 & 14,6 \\
\hline alguma & 104 & 31,6 & 67 & 30,5 & 37 & 33,6 \\
\hline pouca & 133 & 40,4 & 91 & 41,6 & 42 & 38,2 \\
\hline nenhuma & 53 & 16,1 & 38 & 17,4 & 15 & 13,6 \\
\hline não sabe & 7 & 2,1 & 7 & 3,2 & $\mathbf{0}$ & 0,0 \\
\hline familiaridade relativa com PNCM e colegas & 330 & & 219 & & 111 & \\
\hline melhor & 82 & 24,9 & 51 & 23,3 & 31 & 27,9 \\
\hline igual & 141 & 42,7 & 86 & 39,3 & 55 & 49,6 \\
\hline pior & 39 & 11,8 & 30 & 13,7 & 9 & 8,1 \\
\hline não sabe & 68 & 20,6 & 52 & 23,7 & 16 & 14,4 \\
\hline
\end{tabular}

\subsubsection{3. - Atitude do médico: opinião sobre afirmações sobre PNCM}

Praticamente não houve recusa em responder essa parte do questionário; registramos somente uma recusa, quando pedimos a opinião do médico sobre as doze afirmações acerca da PNCM de uma maneira geral. As opiniões mais freqüentes, entre os entrevistados, foram as onze seguintes, mostradas 
aqui,em ordem decrescente:

1 - 67,3\% 'concorda bastante' com "é importante o médico ter algum conhecimento nelas",

2 - $65,4 \%$ 'concorda bastante' com "elas devem ser usadas somente se forem científicas",

3 - 50,8\% 'concorda em parte' com "elas melhoram a qualidade de vida do paciente",

4 - 50,0\% 'concorda em parte' com "elas são perigosas para a saúde do paciente",

5 - 49,7\% 'concorda em parte' com "elas são úteis no tratamento do paciente",

6 - $48,1 \%$ 'concorda em parte' com "da maneira como elas são feitas, oferecem perigo para o paciente",

7 - 47,0\% 'concorda em parte' com "elas devem fazer parte da formação médica",

8 - 44,8\% 'discorda bastante' com "elas devem ser combatidas pela classe médica",

9 - 39,9\% 'concorda em parte' com "elas melhoram o arsenal médico",

10 - 36,5\% 'concorda em parte' com "elas fazem com que o paciente recuse o tratamento convencional",

$11-35,7 \%$ 'concorda em parte' com "elas prejudicam o tratamento convencional".

O resultado por cada afirmação e a intensidade da concordância ou discordância está representado visualmente na Figura 11. Os dados brutos estão no Anexo E. As afirmações que receberam mais de $5 \%$ de resposta "indiferente" foram $\mathrm{H}$ ("elas melhoram a qualidade de vida do paciente") com 5,5\% e L ("é importante o médico receber treinamento nelas") também com 5,5\%. As afirmações que receberam mais de $5 \%$ de resposta "não sabe" foram E ("da maneira como são feitas, oferecem perigo para o paciente") com 6,6\% e H (5,5\%). A afirmação que recebeu maior concordância foi K ("é importante o médico ter algum conhecimento nelas") com 91,2\%; por outro lado, a que recebeu maior discordância foi J ("elas devem ser combatidas pela classe médica") com 69,5\%.

Com relação ao médico ter formação ou treinamento em PNCM, 66,5\% dos médicos acham que elas devem fazer parte da formação médica, 91,2\% acham importante ter algum conhecimento no assunto e $63,1 \%$ acham importante receber treinamento. Quanto ao uso, 85,4\% acham que elas devem ser usadas somente se forem científicas, 64,9\% acham que da maneira como são feitas oferecem perigo para o paciente, $48,0 \%$ entendem que elas fazem com que o paciente recuse o tratamento convencional mas somente $26,1 \%$ acham que elas devem ser combatidas pela classe médica. Quando perguntados sobre a utilidade prática, 81,3\% opinaram que elas são úteis no tratamento do paciente, $74,4 \%$ acham que elas melhoram a qualidade de vida do paciente, $66,5 \%$ acham que elas melhoram o arsenal 
terapêutico do médico, 58,2\% entendem que elas são perigosas para a saúde do paciente e 47,3\% que elas prejudicam o tratamento convencional.

Figura 11: Distribuição da opinião do médico sobre afirmações acerca das PNCM em geral. *

\begin{tabular}{|c|c|c|c|c|c|c|c|c|c|c|c|}
\hline \multirow[t]{2}{*}{ afirmações sobre PNCM } & \multicolumn{6}{|c|}{ concorda } & \multicolumn{5}{|c|}{ discorda } \\
\hline & $\%$ & $\begin{array}{l}1 \\
0 \\
0\end{array}$ & $\begin{array}{l}8 \\
0\end{array}$ & $\begin{array}{l}6 \\
0\end{array}$ & $\begin{array}{l}4 \\
0\end{array}$ & $\begin{array}{l}2 \\
0\end{array}$ & $\begin{array}{l}2 \\
0\end{array}$ & $\begin{array}{l}4 \\
0\end{array}$ & $\begin{array}{l}6 \\
0\end{array}$ & $\begin{array}{l}8 \\
0\end{array}$ & $\begin{array}{ll}1 & \% \\
0 & \% \\
0 & \end{array}$ \\
\hline A elas devem fazer parte da formação médica & 66,5 & & & & & & & & & & 28,3 \\
\hline B elas devem ser usadas somente se forem científicas & 85,4 & & & & & & & & & & 11,1 \\
\hline C elas são úteis no tratamento do paciente & 81,3 & & & & & & & & & & 11,8 \\
\hline D elas são perigosas para a saúde do paciente & 58,2 & & & & & & & & & & 34,2 \\
\hline $\begin{array}{l}\text { E da maneira como são feitas, oferecem perigo para o } \\
\text { paciente }\end{array}$ & 64,9 & & & & & & & & & & 27,4 \\
\hline F elas prejudicam o tratamento convencional & 47,3 & & & & & & & & & & 46,7 \\
\hline $\begin{array}{l}\text { G elas fazem com que o paciente recuse o tratamento } \\
\text { convencional }\end{array}$ & 48,0 & & & & & & & & & & 46,4 \\
\hline H elas melhoram a qualidade de vida do paciente & 74,4 & & & & & & & & & & 14,6 \\
\hline I elas melhoram o arsenal terapêutico do médico & 66,5 & & & & & & & & & & 27,5 \\
\hline J elas devem ser combatidas pela classe médica & 26,1 & & & & & & & & & & 69,5 \\
\hline K é importante o médico ter algum conhecimento nelas & 91,2 & & & & & & & & & & 5,8 \\
\hline L é importante o médico receber treinamento nelas & 63,1 & & & & & & & & & & 30,8 \\
\hline
\end{tabular}

*Valores em \%. Representação aproximada da proporção. A parte clara é referente a opinião concorda ou discorda "em parte" e a parte escura "bastante". O total sempre é menor que 100\% pois em todas afirmações existem resposta "indiferente" e "não sabe". 


\subsubsection{4. - Associação com desfechos de interesse: 'atitude ante PNCM', 'percebe demanda' 'possui treinamento', 'endossa ou prescreve', 'provedor' e características demográficas}

A seguir, apresentamos o resultado de associações de algumas variáveis. Foram considerados, no presente trabalho, como desfechos de interesse, as seguintes variáveis estudadas:

1. atitude do médico ante PNCM;

2. o médico percebe demanda por PNCM;

3. o médico possui treinamento em alguma modalidade de PNCM;

4. o médico endossa ou prescreve pelo menos uma modalidade de PNCM e

5. o médico é provedor de PNCM.

Para identificar os fatores preditores que influenciam essas variáveis, foi feito teste de associação simples entre os desfechos de interesse e características demográficas ${ }^{1}$ (Tabela 18). As seguintes associações mostraram diferença estatisticamente significantes:

\section{- sexo e treinamento:}

as mulheres referiram ter mais treinamento $(p=0,010)$.

- sexo e endossa/prescreve:

as mulheres endossam/prescrevem em maior proporção $(p=0,040)$.

- faixa etária e treinamento:

os médicos com até 30 anos referiram menos treinamento e os entre 41 e 60 anos referiram mais treinamento $(p<0,001)$.

- faixa etária e endossa/prescreve:

os médicos com menos de 30 anos e mais de 60 anos endossam/prescrevem menos e aqueles com idade entre 31 a 50 anos o fazem mais $(p=0,043)$.

- local da escola médica e treinamento:

os médicos graduados em escolas médicas paulistas exceto Capital referiram mais treinamento $(p=0,001)$.

- tempo de formado e treinamento:

os médicos formados há 5 anos ou menos têm menos treinamento e os formados entre 16 e 25 anos referiram mais possuir treinamento $(p<0,001)$.

As categorias das características demográficas são as mesmas vistas em tabelas anteriores. A tabela com os dados brutos não foram apresentada propositadamente para melhor compreensão desta parte pois 1. as mesmas se estendem por dez páginas, 2 . muitos dos resultados aqui vistos na verdade são fatores de confusão como veremos na análise do modelo de regressão e 3 . os resultados somente serão utilizados na Discussão. 
- principal vínculo empregatício e treinamento:

os médicos que indicaram como principal vínculo de emprego a profissão liberal referiram mais treinamento e aqueles assalariados referiram menos $(p=0,027)$.

- principal vínculo empregatício e endossa/prescreve:

os médicos assalariados endossam/prescrevem menos que aqueles cujo vínculo principal é servidor público ou profissional liberal $(p=0,020)$.

- área de atuação como médico e "perceber demanda":

os médicos que atuam em área cirúrgica e pediatria notam mais que existe demanda em PNCM; já os que atuam em área administrativa e "outras especialidades" notam menos ( $p=0,046)$.

\section{- área de atuação como médico e possuir treinamento:}

os médicos que atuam em áreas clínica e cirúrgicas referiram menos treinamento e aqueles que atuam em área pediátrica e "outras especialidades" disseram mais possuirem treinamento $(0,002)$.

- área de atuação como médico e endossa/prescreve:

os médicos que atuam em pediatria endossam/prescrevem mais PNCM; já seus colegas da área clínica o fazem menos $(p<0,001)$.

Também foi notada tendência estatística para as duas associações:

1. tende a endossar/prescrever mais quando a quantidade de pós-graduação foi de um a três $(p=0,062)$ e

2. a atitude ante PNCM tende a ser mais negativa quando tem um ou dois vínculos empregatícios e menos negativa quando tem mais de dois vínculos $(p=0,054)$. 
Tabela 18: Associação simples de variáveis de interesse com características demográficas. N, qui quadrado de Pearson e p.

\begin{tabular}{|c|c|c|c|c|c|}
\hline $\begin{array}{l}\text { Desfechos de } \\
\text { interesse }\end{array}$ & atitude & $\begin{array}{l}\text { percebe } \\
\text { demanda }\end{array}$ & $\begin{array}{l}\text { possui } \\
\text { treinamento }\end{array}$ & $\begin{array}{l}\text { endossa ou } \\
\text { prescreve }\end{array}$ & provedor \\
\hline \multicolumn{6}{|l|}{ Variáveis demográficas } \\
\hline \multirow[t]{3}{*}{ sexo } & 364 & 364 & 331 & 323 & 171 \\
\hline & 2,1061 & 0,3323 & 6,7079 & 6,4147 & 2,7900 \\
\hline & 0,349 & 0,564 & 0,010 & 0,040 & 0,095 \\
\hline \multirow[t]{3}{*}{ faixa etária } & 364 & 364 & 331 & 323 & 171 \\
\hline & 7,3936 & 9,9664 & 23,5577 & 15,9831 & 4,5732 \\
\hline & 0,495 & 0,267 & $<0,001$ & 0,043 & 0,334 \\
\hline \multirow[t]{3}{*}{ local de nascimento } & 364 & 364 & 331 & 323 & 171 \\
\hline & 2,5231 & 4,7415 & 2,1128 & 4,0356 & 0,8688 \\
\hline & 0,641 & 0,315 & 0,348 & 0,401 & 0,648 \\
\hline \multirow[t]{3}{*}{ tipo de escola médica } & 364 & 364 & 331 & 323 & 171 \\
\hline & 3,0290 & 3,0900 & 0,7156 & 2,2861 & 0,0169 \\
\hline & 0,220 & 0,213 & 0,398 & 0,319 & 0,897 \\
\hline \multirow[t]{3}{*}{ local da escola médica } & 364 & 364 & 331 & 323 & 171 \\
\hline & 5,6295 & 5,0252 & 14,1411 & 5,5074 & 0,6810 \\
\hline & 0,229 & 0,285 & 0,001 & 0,239 & 0,711 \\
\hline \multirow[t]{3}{*}{ faixa de tempo de formado } & 364 & 364 & 331 & 323 & 171 \\
\hline & 4,9756 & 9,7046 & 22,6407 & 7,6482 & 3,2143 \\
\hline & 0,760 & 0,286 & $<0,001$ & 0,469 & 0,523 \\
\hline \multirow[t]{3}{*}{ quantidade de pós-graudação } & 364 & 364 & 331 & 323 & 171 \\
\hline & 8,3021 & 12,4825 & 8,6910 & 17,5997 & 4,7310 \\
\hline & 0,599 & 0,254 & 0,122 & 0,062 & 0,450 \\
\hline \multirow[t]{3}{*}{ quantidade de vínculo empregatício } & 363 & 363 & 330 & 322 & 171 \\
\hline & 15,2786 & 4,2153 & 3,1523 & 5,7214 & 1,8053 \\
\hline & 0,054 & 0,837 & 0,533 & 0,678 & 0,614 \\
\hline \multirow[t]{3}{*}{ principal vínculo empregatício } & 362 & 363 & 330 & 322 & 171 \\
\hline & 12,0700 & 13,6159 & 12,6720 & 21,1868 & 3,6526 \\
\hline & 0,280 & 0,191 & 0,027 & $\mathbf{0 , 0 2 0}$ & 0,600 \\
\hline \multirow[t]{3}{*}{ descrição do principal vínculo } & 362 & 363 & 330 & 322 & 171 \\
\hline & 8,1143 & 11,1007 & 1,1147 & 4,6627 & 0,4822 \\
\hline & 0,230 & 0,085 & 0,774 & 0,588 & 0,786 \\
\hline \multirow[t]{3}{*}{ local do vínculo principal } & 363 & 363 & 330 & 322 & 171 \\
\hline & 1,5288 & 3,3700 & 1,8298 & 2,2861 & 3,6487 \\
\hline & 0,958 & 0,761 & 0,608 & 0,892 & 0,302 \\
\hline \multirow[t]{3}{*}{ área de atuação como médico } & 362 & 362 & 329 & 321 & 171 \\
\hline & 4,3357 & 21,3334 & 19,2554 & 43,4278 & 1,2422 \\
\hline & 0,977 & 0,046 & 0,002 & $<0,001$ & 0,941 \\
\hline \multirow[t]{3}{*}{ considera-se generalista ou especialista } & 331 & 331 & 331 & 323 & 171 \\
\hline & 2,6832 & 2,7014 & 3,9606 & 0,6866 & 1,9375 \\
\hline & 0,612 & 0,609 & 0,138 & 0,953 & 0,380 \\
\hline
\end{tabular}




\subsubsection{5. - Modelos de Regressão Linear dos desfechos de interesse: 'atitude ante PNCM', 'endossa ou prescreve', 'provedor' e 'possui treinamento'}

Para compreender as variáveis preditoras dos desfechos de interesse 'atitude', 'endossa e ou prescreve', 'provedor' e 'treinamento', todas as variáveis estudadas foram ajustadas no modelo de regressão logística. O desfecho é sempre dicotômico. Chegamos ao modelo final de regressão pela seleção das variáveis com significância no resultado do teste do Odds ratio (OR). Os fatores de confusão foram descartados.

A Tabela 19 mostra as variáveis que influenciam o desfecho 'atitude'. Para a inferência, a variável 'atitude' foi reagrupada em 'atitude positiva' e 'atitude não-positiva'. Os fatores de "risco" para este desfecho foram três, em ordem decrescente da OR:

1. possuir treinamento em alguma modalidade de $\mathrm{PNCM}(\mathrm{OR}=2,20, \mathrm{p}=0,009$, intervalo de confiança (IC) de $95 \%=1,21-4,03)$;

2. ter tido contato prévio e particular com PNCM (OR=1,92, p=0,001, IC95\%=1,17 - 3,17) e

3. endossar ou prescrever PNCM (OR=1,78, $\mathrm{p}=0,022, \mathrm{IC} 95 \%=1,09-2,92)$.

Tabela 19: Modelo de regressão ajustado para variáveis que influenciam o desfecho 'atitude ante PNCM'. $n=364$.

\begin{tabular}{|c|c|c|c|}
\hline \multirow[t]{2}{*}{ variáveis } & \multicolumn{3}{|c|}{ atitude ante PNCM (positiva / não-positiva) ${ }^{\text {(a) }}$} \\
\hline & OR & $\mathrm{IC}_{95 \%}$ & $p$ \\
\hline treinamento em PNCM & & & 0,009 \\
\hline não possui & 1 & - & \\
\hline possui & 2,20 & $1,21-4,03$ & \\
\hline contato particular com PNCM & & & 0,001 \\
\hline não teve & 1 & - & \\
\hline teve & 1,92 & $1,17-3,17$ & \\
\hline prescreve ou endossa uso de PNCM & & & 0,022 \\
\hline não prescreve ou não endossa & 1 & - & \\
\hline prescreve ou endossa & 1,78 & $1,09-2,92$ & \\
\hline
\end{tabular}

(a) para o modelo, a variável 'atitude' foi reagrupada, obtendo-se 'atitude positiva' e 'atitude não-positiva' (atitude neutra + atitude negativa). 
A Tabela 20 mostra as variáveis que influenciam o desfecho 'endossa/prescreve PNCM'. Os fatores de "risco" para esse desfecho foram quatro:

1. possuir treinamento em alguma modalidade de PNCM $(\mathrm{OR}=4,07, p<0,001, \mathrm{IC} 95 \%=2,02$ 8,20);

2. ter tido contato prévio profissional com $\mathrm{PNCM}(\mathrm{OR}=2,63, \mathrm{p}<0,001$, IC95\%= 1,55 - 4,47);

3. perceber demanda por PNCM em geral $(\mathrm{OR}=2,31, \mathrm{p}=0,049, \mathrm{IC} 95 \%=0,97-5,47)$ e 4 . tender a apresentar atitude positiva com relação a PNCM $(\mathrm{OR}=1,87, \mathrm{p}=0,022, \mathrm{IC} 95 \%=1,34-2,63)$.

Tabela 20: Modelo de regressão ajustado para variáveis que influenciam o desfecho 'prescreve ou endossa uso de PNCM'. n=321.

\begin{tabular}{|c|c|c|c|}
\hline \multirow[t]{2}{*}{ variáveis } & \multicolumn{3}{|c|}{ prescreve ou endossa uso de PNCM (sim / não) } \\
\hline & OR & $\mathrm{IC}_{95 \%}$ & $p$ \\
\hline treinamento em PNCM & & & $<0,001$ \\
\hline não possui & 1 & - & \\
\hline possui & 4,07 & $2,02-8,20$ & \\
\hline contato profissional com PNCM & & & $<0,001$ \\
\hline não teve & 1 & - & \\
\hline teve & 2,63 & $1,55-4,47$ & \\
\hline percebe demanda por PNCM & & & 0,049 \\
\hline não percebe & 1 & - & \\
\hline percebe & 2,31 & $0,97-5,47$ & \\
\hline atitude ante PNCM ${ }^{(\mathrm{a})}$ & 1,87 & $1,34-2,63$ & 0,022 \\
\hline
\end{tabular}

(a) OR médio da tendência entre atitude negativa (-1), atitude neutra (0) e atitude positiva $(+1)$.

A Tabela 21 mostra as variáveis que influenciam o desfecho 'provedor de PNCM'. Os fatores de "risco" para esse desfecho foram três:

1. possuir treinamento em alguma modalidade de $\operatorname{PNCM}(\mathrm{OR}=12,76, \mathrm{p}<0,001, \mathrm{IC} 95 \%=4,05$ $-40,17)$;

2. ter tido contato particular com PNCM (OR = 11,11, p=0,004, IC95\%=1,34 - 91,54) e

3. ter tido contato profissional com PNCM $(\mathrm{OR}=9,98, \mathrm{p}=0,007, \mathrm{IC} 95 \%=1,20-82,87)$. 
Tabela 21: Modelo de regressão ajustado para variáveis que influenciam o desfecho 'provedor de PNCM'. $n=170$.

\begin{tabular}{|c|c|c|c|}
\hline \multirow[t]{2}{*}{ variáveis } & \multicolumn{3}{|c|}{ provedor de PNCM (sim / não) } \\
\hline & OR & $\mathrm{IC}_{95 \%}$ & $\mathrm{p}$ \\
\hline treinamento em PNCM & & & $<0,001$ \\
\hline não possui & 1 & - & \\
\hline possui & 12,76 & $4,05-40,17$ & \\
\hline contato particular com PNCM & & & 0,004 \\
\hline não teve & 1 & - & \\
\hline teve contato & 11,11 & $1,34-91,54$ & \\
\hline contato profissional com PNCM & & & 0,007 \\
\hline não teve & 1 & - & \\
\hline teve contato & 9,98 & $1,20-82,87$ & \\
\hline
\end{tabular}

Nos três desfechos de interesse anteriores, o fator de "risco" mais importante foi o "treinamento prévio em alguma modalidade de $\mathrm{PNCM}^{\prime}$. A Tabela 22 a seguir, mostra os seis fatores que influenciam essa variável 'treinamento'. Pela ordem de relevância:

1. ter idade entre 41 a 50 anos $(O R=8,83, p=0,006, I C 95 \%=1,59-49,08)$;

2. ter tido contato profissional com PNCM $(\mathrm{OR}=8,59, \mathrm{p}<0,001$, IC95\%=3,94 - 18,74);

3. ter tido contato particular com PNCM (OR=5,59, $\mathrm{p}<0,001$, IC95\%=2,36 - 13,22);

4. atuar em 'outras especialidades' $(\mathrm{OR}=3,40, \mathrm{p}=0,014, \mathrm{IC} 95 \%=1,25-9,25)$;

5. atuar em pediatria $(\mathrm{OR}=2,68, \mathrm{p}=0,014, \mathrm{IC} 95 \%=1,06-6,77)$;

6. atitude com relação a PNCM tender para positiva $(\mathrm{OR}=2,13, \mathrm{p}=0,004, \mathrm{IC} 95 \%=1,25$ 3,65) e

7. possuir mais modalidades diferentes de pós-graduação $(O R=1,47, p=0,044, I C 95 \%=1,01$ $2,15)$. 
Tabela 22: Modelo de regressão ajustado para variáveis que influenciam o desfecho 'treinamento em $\mathrm{PNCM}^{\prime} . \mathrm{n}=331$.

\begin{tabular}{|c|c|c|c|}
\hline \multirow[t]{2}{*}{ variáveis } & \multicolumn{3}{|c|}{ treinamento em PNCM (sim / não) } \\
\hline & OR & $\mathrm{IC}_{95 \%}$ & $\mathrm{p}$ \\
\hline faixa etária em anos & & & 0,006 \\
\hline até 30 & 1 & - & \\
\hline 31 a 40 & 4,29 & $0,74-24,87$ & \\
\hline 41 a 50 & 8,83 & $1,59-49,08$ & \\
\hline 51 a 60 & 5,82 & $0,97-34,76$ & \\
\hline 61 e mais & 1,00 & $0,10-10,31$ & \\
\hline contato profissional com PNCM & & & $<0,001$ \\
\hline não teve & 1 & - & \\
\hline teve & 8,59 & $3,94-18,74$ & \\
\hline contato particular com PNCM & & & $<0,001$ \\
\hline não teve & 1 & - & \\
\hline teve & 5,59 & $2,36-13,22$ & \\
\hline área de atuação médica & & & 0,014 \\
\hline especialidades clínicas & 1 & - & \\
\hline especialidades cirúrgicas & 0,64 & $0,23-1,74$ & \\
\hline tocoginecologia & 1,13 & $0,38-3,36$ & \\
\hline pediatria & 2,68 & $1,06-6,77$ & \\
\hline outras especialidades & 3,40 & $1,25-9,25$ & \\
\hline atitude ante PNCM ${ }^{\text {(a) }}$ & 2,13 & $1,25-3,65$ & 0,004 \\
\hline tipos diferentes de pós-graduação ${ }^{\text {(b) }}$ & 1,47 & $1,01-2,15$ & 0,044 \\
\hline
\end{tabular}

(a) OR médio da tendência entre atitude negativa (-1), atitude neutra (0) e atitude positiva (+1).

(b) OR médio da tendência entre quantidade de tipos diferentes de pós-graduação ( 0 a 5). 


\subsubsection{6. - Outras associações de interesse: perceber demanda $X$ atitude}

A associação simples que indica que "perceber demanda" não quer dizer, necessariamente, demanda positiva é mostrada na Tabela 23. A maioria absoluta dos médicos, em todos as categorias de atitude, referiram perceber que existe demanda por PNCM. Ou seja, o médico pode perceber demanda em PNCM e ter atitude negativa. Também notamos uma tendência naqueles que mostraram atitude negativa, dizerem mais 'não' quando perguntados se percebiam demanda.

Tabela 23: Atitude ante PNCM X Percebe demanda por PNCM, n, \% coluna e \% linha.

\begin{tabular}{|c|c|c|c|c|c|c|c|c|c|c|c|c|}
\hline \multirow{3}{*}{$\begin{array}{l}\text { Percebe demanda por PNCM } \\
\text { não }\end{array}$} & \multicolumn{9}{|c|}{ Atitude } & & & \\
\hline & \multicolumn{3}{|c|}{ negativa } & \multicolumn{3}{|c|}{ neutra } & \multicolumn{3}{|c|}{ positiva } & \multicolumn{3}{|c|}{ total } \\
\hline & 8 & 11,2 & 27,6 & 11 & 10,1 & 37,9 & 10 & 5,4 & 34,5 & 29 & 7,9 & 100,0 \\
\hline $\operatorname{sim}$ & 59 & 83,1 & 18,6 & 90 & 82,6 & 28,3 & 169 & 92,3 & 53,1 & 318 & 87,6 & 100,0 \\
\hline não sabe & 4 & 5,6 & 25,0 & 8 & 7,3 & 50,0 & 4 & 2,1 & 25,0 & 16 & 4,4 & 100,0 \\
\hline total & 71 & 100,0 & 19,6 & 109 & 100,0 & 30,0 & 183 & 100,0 & 50,4 & 363 & 100,0 & 100,0 \\
\hline
\end{tabular}

Qui² de Pearson: $p=0,078$

Podemos esmiuçar um pouco a atitude do médico ao perguntar-lhe se PNCM, 1. influencia o resultado do tratamento para o paciente, 2. altera o trabalho do médico e 3. age sobre o resultado terapêutico (Tabela 24).

Muitos se recusaram a responder a indagação se PNCM "influencia resultado para o paciente", geralmente alegando que a pergunta estava mal formulada $(n=251)$. Mas, de uma maneira geral, o grupo dos que percebem demanda por PNCM é onze vezes maior que o grupo dos que não percebem. O aumento da resposta ao questionamento desse tipo, faz aumentar também o número de respostas 'não sabe'. O médico que percebe demanda tendeu a dar respostas positivas.

Metade dos que não percebem demanda acham que PNCM não influencia resultado para o paciente. Por outro lado, dois terços daqueles que percebem demanda acham que há influência positiva para o paciente $(p<0,001)$. Quando perguntados se PNCM altera o trabalho do médico, $40,0 \%$ dos que não percebem demanda acham que não altera; invertendo para $46,6 \%$ dos que percebem demanda acharem que altera positivamente $(p=0,015)$. Sobre se PNCM age sobre o resultado terapêutico, quase 
23\% não souberam dar uma posição. Mas, em ambos os grupos, que percebem ou não demanda, a maior parte entende que PNCM tem ação positiva no resultado terapêutico.

Tabela 24: Percebe demanda X Opinião se PNCM: (1) influencia resultado para o paciente, (2) altera o trabalho do médico e (3) age sobre o resultado terapêutico. $N(\%)$.

\begin{tabular}{|c|c|c|c|c|c|c|}
\hline \multirow[b]{3}{*}{ Influencia resultado para o paciente (a) } & \multicolumn{6}{|c|}{ Percebe demanda (a), (b), (c) } \\
\hline & \multicolumn{2}{|c|}{ não } & \multicolumn{2}{|c|}{$\operatorname{sim}$} & \multicolumn{2}{|c|}{ total } \\
\hline & 21 & & 230 & & 251 & \\
\hline não & 11 & 52,4 & 35 & 15,2 & 46 & 18,3 \\
\hline sim, negativamente & 5 & 23,8 & 33 & 14,3 & 38 & 15,1 \\
\hline sim, positivamente & 5 & 23,8 & 154 & 67,0 & 159 & 63,3 \\
\hline não sabe & $\mathbf{0}$ & 0,0 & 8 & 3,5 & 8 & 3,2 \\
\hline Altera o trabalho do médico (b) & 25 & & 275 & & 300 & \\
\hline não & 10 & 40,0 & 56 & 20,4 & 66 & 22,0 \\
\hline sim, negativamente & 5 & 20,0 & 43 & 15,6 & 48 & 16,0 \\
\hline sim, positivamente & 3 & 12,0 & 128 & 46,6 & 131 & 43,7 \\
\hline não sabe & 7 & 28,0 & 48 & 17,4 & 55 & 18,3 \\
\hline Ação sobre o resultado terapêutico (c) & 29 & & 312 & & 341 & \\
\hline não & 7 & 24,1 & 49 & 15,7 & 56 & 16,4 \\
\hline sim, negativamente & 3 & 10,4 & 17 & 5,4 & 20 & 5,9 \\
\hline sim, positivamente & 13 & 44,8 & 174 & 55,8 & 187 & 54,8 \\
\hline não sabe & 6 & 20,7 & 72 & 23,1 & 78 & 22,9 \\
\hline
\end{tabular}

(a) Pearson chi2(4) $=133,16 \quad p<0,001$

(b) Pearson $\operatorname{chi} 2(4)=18,91 \quad \mathrm{p}=0,015$

(c) Pearson chi2(4) $=13,22 \quad \mathrm{p}=0,104$

\section{anamnese? \\ 4.4.17. - Outras associações de interesse: o médico faz perguntas sobre PNCM na}

Parte considerável, quase $41 \%$, dos médicos que têm contato com paciente, não fazem perguntas sobre uso prévio ou atual de PNCM. Entre os que não prescrevem ou endossam PNCM, esse fenômeno é mais prevalente, chegando a 55,3\%. 28,2\% dos que prescrevem, não perguntam sobre o uso de PNCM na anamnese. Por outro lado, entre aqueles que prescrevem ou endossam, somente 31,2\% perguntam sempre.

O interesse pela PNCM representado pela prescrição ou endosso, ser provedor, perceber 
demanda e ter treinamento, melhora a freqüência da pergunta sobre PNCM na anamnese $(p<0,001$ nas quatro situações).

Chama a atenção que, mesmo entre os que são provedores, somente 58,1\% sempre fazem esse tipo de pergunta e também existem 14\% desse grupo que não perguntam. Fora o fato de ser provedor, que tecnicamente teria mais do que obrigação de incorporar esse tipo de pergunta, o treinamento é o melhor fator que aumenta a freqüência da resposta 'sim, sempre'. (Tabela 25)

Tabela 25: Faz perguntas sobre PNCM na anamnese $X$ prescrição, provedor, percepção da demanda e treinamento em PNCM. n e \%.

\begin{tabular}{|c|c|c|c|c|c|c|c|c|}
\hline \multirow[b]{3}{*}{ prescrição de PNCM $(n=320)^{(a)}$} & \multicolumn{6}{|c|}{ faz perguntas sobre PNCM na anamnese ${ }^{\text {(a) (b) (c) (d) }}$} & \multirow{2}{*}{\multicolumn{2}{|c|}{ total }} \\
\hline & \multicolumn{2}{|c|}{ não } & \multicolumn{2}{|c|}{ sim, depende } & \multicolumn{2}{|c|}{ sim, sempre } & & \\
\hline & 131 & 40,9 & 100 & 31,3 & 89 & 27,8 & & \\
\hline não & 83 & 55,3 & 31 & 20,7 & 36 & 24,0 & 150 & 100,0 \\
\hline $\operatorname{sim}$ & 48 & 28,2 & 69 & 40,6 & 53 & 31,2 & 170 & 100,0 \\
\hline provedor de PNCM $(n=170)^{(b)}$ & 48 & 28,2 & 69 & 40,6 & 53 & 31,2 & & \\
\hline não & 42 & 33,1 & 57 & 44,9 & 28 & 22,0 & 127 & 100,0 \\
\hline $\operatorname{sim}$ & 6 & 14,0 & 12 & 27,9 & 25 & 58,1 & 43 & 100,0 \\
\hline percepção da demanda $(n=310)^{(c)}$ & 123 & 39,7 & 97 & 31,3 & 90 & 29,0 & & \\
\hline não & 15 & 65,2 & 4 & 17,4 & 4 & 17,4 & 23 & 100,0 \\
\hline $\operatorname{sim}$ & 108 & 37,6 & 93 & 32,4 & 86 & 30,0 & 287 & 100,0 \\
\hline treinamento em PNCM $(n=322)^{(d)}$ & 132 & 41,0 & 100 & 31,1 & 90 & 27,9 & & \\
\hline não & 117 & 49,8 & 69 & 29,3 & 49 & 20,9 & 235 & 100,0 \\
\hline $\operatorname{sim}$ & 15 & 17,3 & 31 & 35,6 & 41 & 47,1 & 87 & 100,0 \\
\hline
\end{tabular}

(a) Pearson chi2 (3) $=305,9 \quad p<0,001$

(b) Pearson chi2 (3) $=20,3 \quad \mathrm{p}<0,001$

(c) Pearson chi2 (3) $=28,4 \quad \mathrm{p}<0,001$

(d) Pearson chi2 (3) $=32,9 \quad \mathrm{p}<0,001$

\subsubsection{8. - Comentário no fim do questionário}

A última questão da entrevista foi uma pergunta aberta para aqueles que quisessem fazer algum comentário a respeito do estudo ou do assunto estudado. Dos 364 entrevistados, 98 (26,9\%) fizeram algum tipo de comentário. Os comentários espontâneos dividiram-se grandemente em opinião sobre o estudo ou sobre o assunto e em descrição da experiência sobre o assunto. O comentário mais registrado $(60,2 \%, 59 / 98)$ foi do tipo que "achou a pesquisa interessante, é um estudo válido". Chama a 
atenção também a reclamação com a metodologia do trabalho, misturando várias práticas nãoconvencionais (46,9\%, 46/98). O terceiro tipo de comentário mais feito, 32,7\% (32/98) foram "concordo com algum tipo de PNCM" e "o médico e o estudante de medicina devem ter conhecimento sobre PNCM para torná-las científicas".

A Figura 12 mostra os principais tipos de comentários registrados. O Anexo $\mathbf{F}$ organiza as vários modalidades de comentários com alguns exemplos que doravante serão utilizados para ilustração na Discussão.

Figura 12: Principais tipos de comentários registrados no estudo.

- a pesquisa é interessante

- é um estudo válido

- o questionário(ou a pergunta) foi mal formulado

- é difícil de responder de uma maneira geral para todas as práticas

- existem práticas que não devem ser considerados 'não-convencionais'

- é bom que a universidade faça esse tipo de estudo

- tenho receio da conclusão que será tirada pois pode dar uma imagem falsa

- essas práticas existem

- essas práticas são usadas

- o assunto deve ser estudada pelos médicos

- sou contra essas práticas

- existem práticas úteis e outras não

- concordo (com algumas práticas)

- não gosto (de um tipo específico de PNCM)

- aceito se for cientificamente reconhecido

- faltam profissionais qualificados

- o médico tem que saber orientar esses tratamentos

- a proliferação dessas práticas se deve a carência da medicina convencional

- funciona ou ajuda psicologicamente

- não conheço muito o assunto

- conheço o assunto

- tive treinamento (em algum tipo de PNCM)

- prescrevo ou encaminho (algum tipo de PNCM)

- atrapalha o tratamento

- ajuda o tratamento

- estou me submetendo a (algum tipo de PNCM) 


\section{5 - DISCUSSÃO}

\section{1. - METODOLOGIA}

O desenho deste estudo foi descritivo e transversal e tem a limitação inerente a esse tipo de trabalho. O estudo descritivo limita-se à descrição das características gerais da doença ou de seu fator de risco, enfocando-as sob as perspectivas geográfica, temporal e do indivíduo. Entretanto, sua limitação vem da natureza especulativa do resultado, o qual não permite chegar a conclusões acerca da relação causa-e-efeito do assunto estudado. O desenho transversal faz um retrato do momento e não há um acompanhamento temporal do fenômeno estudado. Portanto não se pode concluir tendências com esse tipo de desenho. Tem a vantagem da facilidade de execução e rapidez na obtenção de resultados, como foi o caso do presente estudo. Serve muito bem ao propósito de fazer prospecções iniciais para um tema novo na investigação médica. Os resultados são geradores de hipótese que deverão ser testadas no futuro e, nesse aspecto, o trabalho foi útil, como veremos adiante.

O questionário foi aplicado por meio de contato telefônico. Embora a população estudada de médicos seja, por característica da profissão, um grupo diferente no sentido de ter acesso a telefone, existem limitações inerentes a esse método. A primeira é não ter acesso a indivíduos que não possuem telefone ou não publicam seu número nas listas telefônicas. A segunda é a questão tempo de aplicação do questionário, o qual não deve ser longo. A terceira é a necessidade de o questionário ser claramente compreensível ao telefone, e isso acaba limitando o desenho do questionário. Tomamos cuidado especial com os quesitos compreensão e audibilidade das perguntas e respostas fazendo dois testespiloto. Nesse particular, as entrevistadoras não relataram dificuldades. Quanto ao questionário, uma limitação deste estudo foi o fato de não ter sido feita validação interna, embora tenha sido feito várias perguntas repetitivas para verificar a coerência da resposta do entrevistado. Justamente devido a esse desenho, outra parte complicada neste estudo foi a relacionada ao consentimento informado. Era impossível fazê-lo da maneira convencional, com leitura de documento de informação, etc., pelo telefone, daí o procedimento descrito no item 3.4.1.. 
Citamos aqui alguns comentários dos entrevistados sobre o questionário:

- Achei o questionário adequado e abrangente. ( $M, 37$, radiologia), ( $M, 56$, psiquiatria)

- O questionário foi muito claro, pesquisa válida. (M, 50, ortopedia e traumatologia)

Por outro lado, a maneira como abordamos o assunto MCA, sem distinção das várias modalidades, desagradou a alguns dos profissionais entrevistados:

- É difícil de responder de uma maneira geral para todas as práticas. (M, 55, clínica geral), ( $F$, 47, homeopatia), ( $M, 43$, cirurgia digestiva), ( $M, 65$, clínica cirúrgica)

- Algumas perguntas se tornam difíceis de responder por ter de fazer uma opção global. (M, 56, endocrinologia), $(M, 42$, cardiologia)

- Não gostei das perguntas genéricas porque há práticas que funcionam pois foram comprovadas e outras não. ( $M, 43$, nefrologia), ( $M, 26$, hematologia)

- Lamento que estejam numa mesma cesta coisas diferentes do ponto de vista médico, não dá para opinar junto sobre essas diferentes coisas. ( $F, 41$, pediatria)

- A pesquisa deveria ter sido feita somente com práticas reconhecidas cientificamente. 0975(M, 29, anestesiologia)

Esse tipo de reclamação já era conhecido quando testamos a metodologia através dos testespiloto. Entretanto, resolvemos correr esse risco já que, de qualquer forma, o assunto é polêmico e nos interessava verificar a reação do médico para com a MCA como um todo e não somente a prevalência de determinados tipos de práticas, regulamentadas ou não.

A idéia inicial do trabalho era terminar a coleta dos dados em três meses, mas acabou se alongando por cinco meses devido a dificuldade de agendamento da entrevista, pois coincidiu com o período de férias do final de ano. O controle de qualidade da aplicação do questionário mostrou-se satisfatório. Trinta e sete médicos que responderam ao questionário foram sorteados para controlar a consistência e confiabilidade dos dados coletados (item 3.3.3.5). Desses, 35 foram novamente encontrados e não houve nenhuma resposta diferente da encontrada pela primeira vez. 


\section{2. - POPULAÇÃO ESTUdADA}

Quando se fala em pesquisa populacional por telefone, o método tradicionalmente mais aceito como científico é a Discagem de Número Aleatório (em inglês, $R D D$, random digit dialing) e suas variantes. Essa técnica permite analisar grandes populações, entretanto não é a mais adequada para se ter acesso a populações específicas, de integrantes determinados. Por outro lado, o método de amostragem não-aleatória para esse tipo de população levanta a questão de quão bem uma amostra representa todo o grupo [Muhib et al., 2001]. Para reduzir esse viés, sorteamos a amostra e essa mostrouse adequada (vide amostra inicial, Tabela 3). Entretanto, a amostra estudada mostrou-se diferente da população estudada, com menos indivíduos mais jovens, com menos de 30 anos, e mais em faixa etária acima de 50 anos $^{1}$. Isso de deve à limitação do desenho do estudo que usou busca de número do telefone por meio de lista publicada; os mais jovens não possuem telefone em seu nome pois muitos vivem em locais provisórios (caso dos residentes, p.ex.), ou com familiares e amigos. A fase inicial da carreira do médico demanda muito deslocamento, portanto para seu estilo de vida, um telefone móvel geralmente é mais útil. Já os médicos mais velhos estão estabelecidos e muitas vezes encontramos vários endereços ou vários telefones no mesmo endereço. Nesse aspecto, é mais fácil encontrar um telefone comercial com essa metodologia, pois é fácil supor que aqueles indivíduos "casados" tenham o telefone em nome de um dos cônjuges, quando o telefone é residencial.

Os médicos constituem um grupo populacional à parte no quesito pesquisa populacional. Kellerman e Herold [2001] mostram que os médicos apresentam maior recusa em participar de estudos do tipo populacional do que a população geral. Um valor baixo de taxa de resposta faz com que os achados tenham menos confiabilidade e representatividade pois, nesses casos, é maior a chance de estarmos lidando com opiniões extremas, tanto positivas quanto negativas para o assunto estudado. Se usarmos o presente estudo como exemplo, seriam os extremamente céticos ou os extremamente deslumbrados com a MCA. Para reduzir esse problema, algumas táticas são usadas; em alguns países, onde a pesquisa por questionário postado é comum, lembretes (reminders) feitos por meio de contato telefônico [Salim-Silva et al. 2002] diminuem a taxa de recusa. Outra estratégia é o reenvio do questionário, de tempos em tempos, como foi feito no trabalho revisado de Thomas, Coleman, Nicholl [2003]. No nosso estudo, instituímos o "grau de insistência", dando até cinco chances de agendamento da entrevista, resultando numa taxa de recusa de $32 \%$. Aqueles indivíduos que recusaram participação no estudo mostraram algumas características: têm mais idade $(p=0,026)$, e trabalham em ambiente

1 Conseguimos deduzir isso pelo número do CRM. 
cirúrgico (cirurgia e tocoginecologia) $(\mathrm{p}=0,023)$. Ao serem contatados pela segunda vez para coleta desses dados, cerca de 10\% recusaram novamente de maneira expressa. Essa parcela sugere que é muito difícil fazer um estudo populacional com médicos com mais de 90\% de taxa de resposta.

\section{3. - CARACTERÍSTICA DEMOGRÁFICA}

Em relação a esse grupo de variáveis no estudo, observamos que: 1) metade dos médicos da amostra nasceu em São Paulo, 2) são três homens para cada mulher, 3) as médicas são mais jovens, 4) antigamente havia mais escola pública que privada, 5) menos de um terço dos médicos são formados no próprio Município, 6) cerca de $60 \%$ são formados entre 6 e 25 anos, 7) é muito comum o médico ter duas pós-graduações, sendo uma delas residência ou especialização, 8) o médico tem dois vínculos de emprego, comumente emprego público e trabalho como profissional liberal, 9) o médico trabalha com atividade clínica em consultório ou em hospital, 10) os médicos são mais cirurgiões e as mulheres mais pediatras. Há claramente diferenças entre os sexos na formação e no trabalho médicos.

Apesar de grande mudança nas relações de trabalho médico com a "superação da medicina liberal" [Schraiber, 1993, p.131-46], ainda há o sonho do profissional liberal, sendo essa condição referida por quase $80 \%$ dos médicos (que cai para $47 \%$ quando indagados se é a mais importante do ponto de vista do trabalho). A maioria tem mais de um vínculo de emprego e esse vínculo é de atividade clínica. Na atividade médico-administrativa, foi encontrado mais do dobro de indivíduos do sexo masculino.

O Município de São Paulo mostrou ser cosmopolita também em relação aos médicos. Os tipos de atividades médicas são tão heterogêneos, que não ficam atrás de quaisquer países industrializados. Notamos aumento de inclusão de mulheres na carreira médica há cerca de 30 anos, atualmente parece não haver prevalência de sexo entre os recém formados. Uma característica interessante da amostra estudada é a relativa diminuição de quantidade de médicos com CRM na faixa de 70.000 a 80.000 . São aqueles com um pouco mais de cinco anos de inscrição, e que deixaram a cidade após seu curso de pós-graduação como a Residência ou a Especialização. Esse fato e também a diversidade de escolas médicas da graduação encontrada nesta pesquisa provam que o Município de São Paulo é um centro formador de profissionais médicos. 


\section{4. - PREVALÊNCIA DA PNCM}

A PNCM foi bastante prevalente no cotidiano dos médicos moradores da cidade de São Paulo. Do ponto de vista do contato profissional, somente 5,8\% referiram não ter tido contato; quando se passou para o plano privado, 1,8\% referiram não ter tido contato próprio ou de algum familiar próximo. Os médicos na sua maioria, 87,6\% disseram perceber que há demanda por PNCM na sociedade. Deve ficar claro que perceber demanda não quer dizer que essa percepção seja positiva. Neste estudo, 18,6\% dos médicos que referiram perceber demanda mostraram atitude negativa com PNCM.

Comentários que mostram que notar demanda não quer dizer assumir atitude necessariamente positiva:

- O estudo é de extrema valia porque essas práticas existem e se mal usadas são perigosas. (M, 53, pediatria)

- Vejo com preocupação a adesão cega a essas práticas, creio que há limites e os tratamentos devem ser conjuntos. (M, 46, clínica médica)

- O assunto está em evidência na mídia e precisa ser desmistificado. A maioria atrapalha o trabalho médico. (M, 48, ortopedia)

\section{5. - ATITUDE}

Em relação à atitude, 50\% dos médicos apresentaram atitude positiva ante as PNCM. Se raciocinarmos ao contrário, teremos que metade dos médicos apresentaram atitude não-favorável com PNCM. Esse fato pode ser explicado pela falta de familiaridade com o assunto, somente cerca de $10 \%$ conseguem dizer que tem muita familiaridade com PNCM. Logo, a atitude é pouco influenciada pela familiaridade.

Os médicos estudados consideraram que a PNCM não é algo a ser combatida mas devem ser usadas somente se forem científicas; acham que essas práticas são úteis no tratamento para o paciente mas oferecem perigo da maneira como são feitas atualmente. É possível que o profissional médico esteja vendo a PNCM com desconfiança pois não são regulamentadas devidamente. Vejamos alguns comentários a respeito:

- O assunto é atual. Eu lamento não conhecer mais, é preciso partir para novas formas de terapêuticas. $(F, 47$, ginecologia e obstetrícia) 
- É necessário que a classe médica conheça o assunto para torná-la científica. ( $F$, 53, medicina de família)

- Todas as práticas alternativas em medicina podem ser realizadas desde que tenham embasamento científico.

( $M, 41$, ginecologia e obstetrícia)

- Há poucos profissionais capacitados que inspire confiança. (M, 40, reumatologia)

- Em alguns casos considero essas práticas úteis, em muitos não. ( $M$, 38, nefrologia) ( $M$, 35, oftalmologia)

- Algumas técnicas são interessantes mas acho que sempre devem ser aplicadas por médicos com mais conhecimento. Também existe o perigo dos não médicos. $(F, 47$, pediatria)

- É bom que alguém está interessado em uma prática mais responsável. O médico ainda vê essas práticas de uma forma muito obscura. (M, 43, clínica médica e UTI) (M, 57, homeopatia)

- Com a acupuntura concordo mas com outras práticas sou totalmente contra. Aliás, a acupuntura nem deveria ter sido incluida como PNCM. (M, 31, ortopedia)

A freqüência de atitude positiva encontrada é muito semelhante à descrita em trabalhos feitos em outros países e já vistos na Introdução. Mesmo se considerando a 'estimativa mais baixa' (todos os que recusaram teriam atitude não-positiva $\left.{ }^{1}\right)$ teremos $(184 /(172+364)) * 100=34,3 \%$, ou seja, com certeza, pelo menos um terço dos médicos tem atitude positiva ante PNCM. Desse modo, podemos dizer que de um em três a um em dois médicos paulistanos vêem a PNCM "com bons olhos".

A metodologia empregada neste trabalho, para medir a atitude do médico, mostrou-se correta. A "atitude" foi uma das variáveis que influenciaram o desfecho "treinamento em PNCM". É difícil imaginar que alguém iniciaria uma experiência como treinamento não tendo uma atitude favorável.

- Aceito acupuntura, fitoterapia e homeopatia e estou tendo treinamento nestas práticas. $(F, 46$, pediatria)

Entretanto, a experiência pode ser ruim de tal maneira que pode acabar influenciando a opinião, e por conseguinte a atitude, como foi visto no Capítulo Introdução.

- Tenho bastante conhecimento em algumas práticas e estou convencido que elas não servem para nada; logo não concordo. ( $M, 37$, neurocirurgia)

- Fiz cursos, então conheço um pouco. Há práticas boas e outras ruins, $80 \%$ dos homeopatas são picaretas. (M, 40, ginecologia)

- Existem práticas boas e outras ruins, usei acupuntura e homeopatia e encaminho para acupuntura. (F, 36, UTI)

1 O que provavelmente não seja verdade pois estão incluídos médicos provedores de PNCM no grupo, vide Figura 10, pg 37. 


\section{6. - VIVÊNCIA COM PNCM}

As análises com modelo de regressão mostraram que os fatores sempre presentes nos desfechos de interesse relacionados à experiência" foram o "treinamento" e o "contato", ora profissional, ora particular. Ambos não foram proporcionadas sistematicamente, pela instituição médica. Na atual conjuntura, é de se supor que o médico que busca treinamento, o faz por uma atitude ativa. Já o contato pode ser mais casual, sem intenção muitas vezes. São relatos dos entrevistados:

- Não tive nada disso na minha formação médica. (M, 48, clínica médica e cardiologia) (M, 52, UTI)

- As respostas para algumas questões são as experiências pessoais dentro da minha área. ( $F$, 45, dermatologia)

- Acho que deve ser utilizadas para o crescimento pessoal e intelectual do médico. Cada um deve procurar e não tem que ser curricular não. ( $M, 43$, ginecologia e obstetrícia)

- As PNCM devem ser ensinadas na faculdade e se o aluno tiver interesse, deve buscar conhecimento após a graduação. (M, 38, pediatria)

- Tive contato com algumas PNCM quando atuei como clínico geral. Tenho treinamento em homeopatia e acupuntura. (M, 49, anestesiologia)

- Eu estou muito bem impressionado com acupuntura, passei por um tratamento bem sucedido. Mas sou descrente da homeopatia, florais e ortomolecular. (M, 59, pediatria)

A abordagem sociológica enfoca a questão da mediação entre o indivíduo e a sociedade. Mutuamente se influenciam, tensionam, modificam. O sujeito estudado (o médico) faz parte de uma classe social (a classe médica) e essa última também da sociedade global (a sociedade leiga). Logo, a classe médica pode ser sociedade ou indivíduo. Segundo a noção de habitus [Bourdieu, 2002; p.27], as ações sociais são concretamente realizadas pelos indivíduos, mas as chances de efetivá-las encontramse objetivamente estruturadas no interior da sociedade global. O ato médico, o sistema médico, o mercado médico portanto, são objetivamente, regulados pela sociedade.

Nos primórdios da opção por alguma prática não-convencional, o médico, nesse momento, de ruptura ou rebeldia, pois não foi essa sua formação, seguramente estava calcado mais pelas convicções filosóficas que pelas exigências de mercado. Dependendo da dimensão de seu aprendizado

$1 \quad$ Prescrever, endossar, ser provedor 
passado, de sua história pessoal, possivelmente estava mais preocupado com sua eficácia absoluta como médico do que com sua inserção na sociedade. Enquanto essa força individual é pequena dentro da sociedade, como sistema, é geralmente taxada de excêntrica, descontente, etc. Mas o médico nãoconvencional vai encontrar espaço para sua prática na sociedade, agora como mercado, pequeno, no início. O campo que é uma arena de eterna tensão, segundo Bourdieu [2002], é um espaço onde se manifestam as relações de poder (no caso, as instituições médicas), passa a sofrer pressão interna quando os sujeitos descontentes passam a buscar instrumentos do grupo dominante (a medicina convencional, a ciência, a institucionalização) para fazer parte da mesma. Ainda pode não ser um argumento convincente para sua legitimação. Entretanto, quando a sociedade global passa a exercer pressão externa, como colocado anteriormente, proveniente dos pacientes e, por conseguinte, estressa o grupo dominante via mercado, o campo vai tentar se fechar para manter o poder. Para tal, pode usar instrumentos ou parte do conhecimento dos indivíduos "descontentes" visando à sua incorporação. O grupo dominante tem mais facilidade em lidar com 'componentes' do que 'sistemas completos' (o que explicaria a diferença da velocidade de aceitação da homeopatia e da acupuntura entre os médicos brasileiros ${ }^{1}$, essa última em muito menos tempo). Com a modificação do próprio habitus da medicina, seu integrante passa a ser influenciado e visualiza uma oportunidade de mercado, podendo abraçá-la. É o passo para aumentar a pressão interna para a incorporação de uma determinada prática, no grupo dominante.

Existe, portanto, diferença entre os médicos que optaram pela PNCM no início do movimento "alternativo" e os que embarcaram mais à frente. Os primeiros, como o fizeram por opção filosófica, subjetivista, tendem a ser mais 'puristas', porém às vezes mais radicais, com maior dificuldade para tomar uma posição mais pragmática. Os últimos, como o fizeram por opção cientificista, objetivista, tendem a ser mais pragmáticos, às vezes multiperformáticos, às vezes mais levados por interesses de mercado.

\section{7. - RECUSA}

Acreditamos que o assunto PNCM é polêmico. Mesmo com metade dos médicos assumindo posição favorável em relação a ela, seguramente ainda constitui um tabu, algo relacionado a

Barnes [2003] escreveu um artigo interessante sobre a integração da MCA no sistema convencional usando-se o exemplo do caso da acupuntura no Estado de Massachusetts, EUA. Quando para uns a integração com a medicina convencional é interessante, e usa método dela, para outros, mesmo praticando semelhante modalidade de PNCM tem interesse em preservar certa distância e um ar misterioso. 
charlatanismo para uma parte considerável da classe médica. Vários fatos citados neste estudo mostram claramente essa orientação. A reportagem citada no Capítulo Introdução é uma delas mas a não participação (logo a falta de interesse) de instituições de classe médica como foi o caso do CRM e APM em relação a este estudo é bastante representativa. Mesmo durante a entrevista, muitos médicos se recusaram a responder a várias perguntas; de longe a que foi mais recusada foi a pergunta se a PNCM influencia o resultado terapêutico para o paciente: 29,9\% optaram por não responder. Os comentários representativos do exposto acima são:

- As PNCM são muito distintas e agrupá-las em uma pesquisa não vejo como possa chegar a um resultado. A comparação e análise em conjunto não vejo que leve a alguma conclusão. (M, 62, ortopedia)

- Tenho muito receio da conclusão que será tirada. ( $M, 37$, neurocirurgia)

- Práticas alternativas pressupõe curandeirismo e não medicina. ( $F$, 46, homeopatia)

- O CFM deveria se posicionar melhor quanto a essas práticas. Acredito em acupuntura, homeopatia e fitoterapia, o resto é picaretagem. $(F, 52 \text {, ginecologia e obstetrícia })^{1}$

- A proliferação das práticas se dá por carência nas questões humanas no tratamento convencional. (M, 52, saúde pública) (M, 75, professor de medicina)

- Não gosto de medicina alternativa. ( $F, 47$, pronto socorro)

- O questionário foi mal formulado, misturou tudo; nem a medicina convencional é científica e hipnose não é medicina alternativa. ( $M, 62$, ortopedia)

- Quem fez o questionário não fez bem feito, as perguntas estão mal formuladas pois algumas coisas a gente acredita, em outras não. ( $M, 52$, urologia) ( $F, 52$, ginecologia e obstetrícia)

- A pesquisa deveria ter sido feita somente com práticas reconhecidas cientificamente. (M, 29, anestesiologia)

- Devem ser ensinadas para os médicos saberem diferenciar tabus e práticas válidas. ( $M, 49$, pediatria)

- É preciso que os médicos tenham algum conhecimento nessas práticas pois há procura e também muitos tabus. ( $F$, 30, medicina de família)

- Creio que deve ser discriminado o charlatanismo e os médicos são os melhores indicados para avaliar essas terapias sem que haja preconceito, o que noto ser muito forte na classe médica. (M, 53, cirurgia geral)

\section{8. - O MÉDICO QUER TER CONHECIMENTO}

A afirmação que recebeu maior número de concordância no questionário foi sobre a importância do médico ter alguma informação. O médico sente-se meio perdido na conjuntura atual onde o alto nível de prevalência de uso por parte dos pacientes faz com que seu contato seja "quase

\footnotetext{
1 Veja a posição e versão do CFM em Dantas [1999].
} 
inevitável". Na verdade, o médico não quer ter conhecimento para poder aumentar seu arsenal terapêutico. Ele quer ter esse tipo de conhecimento para poder melhorar a comunicação com o seu paciente. Winslow e Shapiro [2002] mostram que os médicos não se sentem confortáveis com a MCA porque não possuem conhecimento suficiente para discutir os riscos ou benefícios dela com os pacientes. Os pacientes também sabem disso, e não contam que estão usando MCA para o seu médico convencional [Eisenberg, 1997]. Neste estudo, menos de 30\% dos médicos que clinicam faziam sistematicamente perguntas sobre uso atual ou anterior de MCA durante a anamnese. Os médicos querem educação que atualmente a instituição médica não está oferecendo:

- Essas práticas já se difundiram bastante, os pacientes fazem muito uso e os médicos não tem conhecimento para saber lidar com essas situações. ( $F, 31$, endocrinologia)

- Acho que o assunto PNCM deveria fazer parte do curso de medicina para os médicos poderem orientar e indicar melhor. ( $M, 27$, clínica médica) $(F, 42$, pediatria)

- Seria importante introduzir nos cursos de graduação, noções básicas sobre cada prática para conhecer indicações e utilidades do uso pelo paciente. ( $F, 43$, pediatria) ( $F, 42$, ginecologia e obstetrícia) ( $F, 30$, endocrinologia)

- Acho que a medicina alternativa atrapalha sim a prática médica e deveria haver aula sobre o assunto na graduação. ( $M, 47$, cardiologia)

- Tem muita gente fazendo coisas que não tem aptidão para isso, é importante estudar. ( $F, 48$, dermatologia)

- A medicina só tem a ganhar com este tipo de preocupação. Abrir espaço afinal, é ganho de cura do paciente independentemente de qual prática. ( $F, 46$, dermatologia)

\section{9. - PERFIL DO MÉDICO "ENGAJADO"}

Embora a maior parte seja fator de confusão quando consideramos para fazer análise de regressão, a associação simples de características demográficas com características da experiência com MCA, é útil para se ter o perfil mais direto dos que tem ou passam por essa experiência; é mais facil visualizar. P. ex. suponhamos que as médicas são mais favoráveis a PNCM porque são mais numerosas em área de atuação que usa mais MCA. Daí, somente o fato de ser um médico do sexo feminino, temos mais chance de estar com alguém engajado em PNCM. Assim, o presente trabalho mostrou que o perfil do médico favorável a PNCM é: mulher, com idade entre 31 e 51 anos, formada em escola do interior paulista (e mora na Capital) que atua como profissional liberal em pediatra ou em "especialidades menores". 


\section{6 - CONCLUSÕES}

\section{1. - CONCLUSÕES}

1. Atitude:

a. $\quad 50 \%$ dos médicos mostra atitude favorável, outros 50\% não-favorável

b. $64 \%$ refere pouca ou alguma familiaridade com PNCM; $24,9 \%$ acha que sua familiaridade é melhor que a dos colegas

c. as variáveis que influenciam a atitude são: treinamento em PNCM e contato particular com PNCM

2. Presença de práticas não-convencionais na rotina do médico:

a. $87,6 \%$ percebe demanda por PNCM

b. $52,2 \%$ referiu ter tido contato profissional

c. $\quad 52,1 \%$ endossa ou prescreve pelo menos uma modalidade de PNCM

d. $13,3 \%$ dos médicos que clinicam são provedores de alguma modalidade de PNCM

e. as variáveis que influenciam o desfecho endossa ou prescreve são: treinamento em PNCM, contato profissional com PNCM, percebe demanda por PNCM, atitude ante PNCM

f. as variáveis que influenciam o desfecho provedor são: treinamento em PNCM, contato particular com PNCM, contato profissional com PNCM

3. Treinamento em PNCM

a. $26,9 \%$ procurou treinamento e desses, $75,3 \%$ concluiram treinamento $(20 \%$ do total)

b. $91,2 \%$ concorda ser importante o médico ter algum conhecimento em PNCM, $63,1 \%$ concorda ser importante o médico receber treinamento em PNCM, 66,5\% concorda que PNCM deve fazer parte da formação médica

c. as variáveis que influenciam o desfecho treinamento são: faixa etária, contato 
profissional, contato particular, atuar em algumas especialidades médicas, atitude positiva e possuir mais modalidades diferentes de pós-graduação

4. Experiência com PNCM

a. quando teve contato profissional, a impressão do contato foi boa em $68,4 \%$

b. quando teve contato profissional, a impressão do contato foi boa em $74,4 \%$

c. $61,5 \%$ acha que PNCM influencia positivamente o resultado terapêutico para paciente

d. $\quad 42,8 \%$ acha que PNCM altera positivamente o trabalho do médico

e. $53,2 \%$ acha que PNCM age sobre o resultado do tratamento

f. $\quad 41,0 \%$ não faz pergunta sobre uso de PNCM na anamnese

5. Conhecimento em PNCM

a. a grande maioria referiu ter nenhum, pouco ou algum conhecimento em PNCM

b. menos de $10 \%$ dos médicos se sentem familiarizados com PNCM

c. o treinamento altera a intensidade do conhecimento

d. as PNCM que os médicos mais referiram conhecimento foram: acupuntura, homeopatia, terapia em grupo, terapias nutricionais, massagens, fitoterapia européia e meditação

6. Coleta de dados por meio de telefone em população de médicos

a. a metodologia empregada permitiu localizar $53,7 \%$ de uma amostra aleatória de médicos paulistanos. 


\section{2. - CONSIDERAÇÕES FINAIS}

O presente estudo, embora tenha as limitações inerentes da metodologia empregada, foi capaz de sugerir que a MCA é prevalente na rotina médica e que metade dos médicos residentes no Município de São Paulo mostram atitude favorável a pelo menos uma modalidade dela. Provavelmente isso não deve significar que esses médicos aceitam a MCA como uma panacéia ou algo que vem resolver os problemas enfrentados no dia-a-dia da medicina mas sim um indicativo que esse tipo de conhecimento pode ser útil para a prática médica. Existiria um 'interesse cauteloso' quando os médicos se posicionam que a MCA "não deve ser combatida pela classe médica" ao mesmo tempo que entende que "devem ser usadas somente se forem científicas".

Entretanto, antes de se discutir amplamente dentro da instituição médica quais modalidades serviriam para esse intuito, e como suportariam uma clarificação admissível para a classe médica, a sociedade leiga partiu para a aceitação do uso da MCA. Tal aceitação não foi resultado de uma ação direta, concreta dos médicos. Nesse sentido, é razoável pensar que o médico sente-se em situação embaraçosa, principalmente aqueles que têm contato direto com pacientes, pois a despeito de ser o profissional legalmente habilitado e socialmente aceito para cuidar da saúde das pessoas, geralmente tem somente "alguma" ou "pouca familiaridade" com MCA.

Desse modo, entendemos ser de suma importância proporcionar educação médica sobre MCA, para dar condições ao médico de lidar com a situação verificada neste estudo. Essa educação não quer dizer necessariamente treinamento, mas sim oferecer conhecimento. Com isso, e somente com a educação, o profissional poderá se posicionar, ter e dar opinião sobre o assunto que causa impacto na saúde do paciente; em última análise, a própria razão de ser do médico. 


\section{7 - ANEXOS}

\section{ANEXO A}

Metodologia > Instrumento do estudo $\mathrm{n}^{\circ}$ um $>$ O questionário.

\section{ANEXO B}

Metodologia > Coleta de dados $>$ Padronização de variáveis e de terminologia utilizadas no estudo.

\section{ANEXO C}

Metodologia > Análise de dados > Critérios usados para categorização da variável 'área de atuação médica' encontrada na amostra.

\section{ANEXO D}

Resultados > Formação > Escolas de medicina de graduação dos médicos que responderam o questionário.

\section{ANEXO E}

Resultados $>$ Atitude $>$ Distribuição da opinião sobre afirmações acerca das PNCM em geral.

\section{ANEXO F}

Resultados > Comentários > Registro de comentários feitos pelos entrevistados. 
ANEXO A. Instrumento do estudo n um: 0 questionário.

ID sujeito $\mathrm{N}^{\circ}$

Vamos começar então o questionário para saber a sua opinião e vivência com práticas não-convencionais em medicina.

Em primeiro lugar, vêm as perguntas sobre a sua pessoa.

01. Qual é o mês e ano de seu nascimento?

(mês) [ ] (ano) [ ]

》〉 anotar sexo do entrevistado [ ] Masc

[ ] Fem

02. Qual é o município onde o(a) sr(a). nasceu?

Em que estado fica?

As próximas perguntas são sobre a sua formação médica.

03. Em que faculdade de medicina o(a) sr(a). se formou?

04. Qual foi o ano de formatura? 19

05. O(a) sr(a). fez algum curso após a graduação? Vou ler uma lista de tipos de cursos, diga sim ou não para cada um deles; e se sim qual foi a área.

z) não fez cursos

a) residência médica

b) especialização fora

residência

c) mestrado

d) doutorado

e) algum outro tipo de curso relevante para sua

carreira

06. Agora vamos passar para as suas atividades médicas no momento, sobre os tipos de vínculos empregatícios que possui atualmente. Vou ler uma lista de vínculos e diga sim ou não para cada um deles.

a) servidor público ou emprego público

b) profissional liberal ou autônomo

c) assalariado no setor privado, incluindo fundações

d) empresário ou proprietário de negócios que empregam médicos

e) cooperado

f) outros, qual

〉〉 se houver apenas um vínculo, vá para Q.09

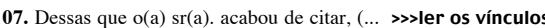

marcados na Q. anterior) qual o(a) sr(a). considera o principal? a) servidor público ou emprego público

b) profissional liberal ou autônomo

c) assalariado no setor privado, incluindo fundações

d) empresário ou proprietário de negócios que empregam médicos

e) cooperado

f) outros

08. Qual a proporção do tempo do seu trabalho que esta atividade principal toma?

09. Qual das seguintes alternativas melhor retrata esta atividade principal?

a) atividade clínica

b) docência ou pesquisa

c) atividade administrativa

d) outros, qual?

10. Onde é feita esta atividade?

11. $\mathrm{O}$ (a) sr(a). clinica? Tem contato com pacientes?

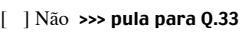

[ ] Sim

12. Qual a sua área de atuação?

13. Dentro da sua área de atuação e na maior parte do tempo, o(a) sr(a). se considera um médico generalista ou especialista?

[ ] generalista

[ ] especialista

[ ] não sabe

Vamos passar agora para as perguntas sobre as práticas não-convencionais em medicina. Gostaria de lembrar que essas práticas são aquelas que não fazem parte da formação médica na graduação. São as chamadas medicinas ou terapias alternativas e vão desde técnicas usadas por médicos como acupuntura ou fitoterapia até métodos populares como a garrafada ou benzedeira passando pelas terapias oferecidas por centros esotéricos. Embora reconhecidos pelo Conselho Federal de Medicina, na definição que estamos usando, fazem parte a acupuntura e a homeopatia. De acordo?

14. Profissionalmente, o(a) sr(a). já teve ou está tendo algum tipo de contato com práticas não-convencionais em medicina?

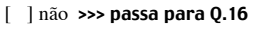

[ ] $\operatorname{sim}$ 
ANEXO A. Instrumento do estudo no um: O questionário. - 2/4

15. Neste caso, qual foi a impressão deste contato: boa, indiferente, ruim ou não sabe?

a) boa

b) indiferente

c) ruim

d) não sabe

16. Houve até agora, uso próprio dessas práticas, ou de algum familiar próximo?

[ ] ] não 〉> passa para Q.18

[ ] sim

17. Neste caso, qual foi a impressão deste contato: boa, indiferente, ruim ou não sabe?

a) boa

b) indiferente

c) ruim

d) não sabe

18. Bem, conversamos até aqui sobre seu contato com práticas não-convencionais em medicina. A seguir, gostaria de conhecer sua opinião de uma forma geral a respeito desse tipo de prática. Farei algumas afirmações sobre elas, e diga se concorda ou discorda destas afirmações. O(a) sr(a). tem 6 opções para resposta:

$$
\begin{aligned}
& \text { •(1) concorda bastante } \\
& \text { •(2) concorda em parte } \\
& \text { •(3) indiferente } \\
& \text { •(4) discorda em parte } \\
& \text { •(5) discorda bastante } \\
& \text { •(9) não sabe }
\end{aligned}
$$

Nas afirmações, entende-se por elas as práticas não-convencionais em medicina. De acordo? Podemos começar?

[ ] "elas devem fazer parte da formação médica"

[ ] "elas devem ser usadas somente se forem científicas"

[ ] "elas são úteis no tratamento do paciente"

[ ] "elas são perigosas para a saúde do paciente"

[ ] "da maneira como elas são feitas, oferecem perigo para o paciente"

[ ] "elas prejudicam o tratamento convencional"

[ ] "elas fazem com que o paciente recuse o tratamento convencional"

[ ] "elas melhoram a qualidade de vida do paciente"

[ ] "elas melhoram o arsenal terapêutico do médico"

[ ] "elas devem ser combatidas pela classe médica"

[ ] "é importante o médico ter algum conhecimento delas"

[ ] "é importante o médico receber treinamento nelas"
As próximas duas perguntas são sobre a sua familiaridade com práticas não-convencionais em medicina.

19. Em geral, como o(a) sr(a). diria que é a sua familiaridade com essas práticas: muita, alguma, pouca, nenhma ou não sabe?

a) muita

b) alguma

c) pouca

d) nenhuma

e) não sabe

20. Em comparação com outros colegas médicos, como o(a) sr(a). diria que é sua familiaridade com essas práticas: melhor, igual, pior ou não sabe?

a) melhor

b) igual

c) pior

d) não sabe

Gostaria de conhecer agora, sua vivência com as práticas das quais viemos falando. Volto a reafirmar que estamos falando destas práticas de uma maneira geral; não é especificamente de algum tipo. De acordo?

21. $\mathrm{O}$ (a) sr(a). percebe que existe demanda por parte dos pacientes por estas práticas?

[ ] não

[ ] sim

[ ] não sabe

22. $\mathrm{O}(\mathrm{A}) \mathrm{sr}(\mathrm{a})$. nota que esta forma de prática tem trazido influências sobre o resultado terapêutico para o paciente?

[ ] não

[ ] sim, influencia positivamente

[ ] sim, influencia negativamente

[ ] não sabe

23. $\mathrm{O}(\mathrm{A}) \operatorname{sr}(\mathrm{a})$. acha que o uso de tais práticas promove alteração nos resultados do trabalho para o médico?

[ ] não

[ ] sim, altera positivamente

[ ] sim, altera negativamente

[ ] não sabe

24. Para o(a) sr(a)., essas práticas têm alguma ação sobre o resultado terapêutico?

[ ] não

[ ] sim, age positivamente

[ ] sim, age negativamente

[ ] não sabe 
ANEXO A. Instrumento do estudo n um: $O$ questionário. - 3/4

25. Na sua anamnese, o(a) sr(a). faz perguntas sobre o uso prévio

ou atual de práticas não-convencionais em medicina?

[ ] não

[ ] sim, eventualmente ou dependendo do caso

[ ] sim, sempre

[ ] não se aplica

26. Na sua prática médica, o(a) sr(a). indica o uso de alguma

forma destas práticas?

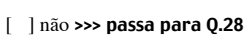

[ ] $\operatorname{sim}$

[ ] ] não se aplica »» passa para Q.28

27. $\mathrm{O}(\mathrm{A}) \operatorname{sr}(\mathrm{a})$. mesmo que faz ou aplica o tratamento indicado?

[ ] não

[ ] sim

28. $\mathrm{O}(\mathrm{A})$ sr(a). já recebeu alguma espécie de treinamento em práticas não-convencionais em medicina?

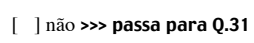

[ ] $\operatorname{sim}$

29. Este treinamento foi concluído?

[ ] não

[ ] $\operatorname{sim}$

30. Este treinamento ocorreu em instituição acadêmica?

[ ] não

[ ] $\operatorname{sim}$

31. Gostaria de conhecer seu nível de conhecimento em algumas práticas não-convencionais. Direi o nome de um tipo e o(a) $\operatorname{sr}($ a) me responde se tem 'nenhum'(N), 'pouco'(P), 'algum'(A) ou 'bastante'(B) conhecimento. De acordo? Posso começar?

[ ] acupuntura

[ ] homeopatia

[ ] quiropatia ou manipulação de colunas

[ ] fitoterapia ocidental ou européia

[ ] medicina tradicional chinesa ou oriental

[ ] medicina biomolecular ou de radicais livres

[ ] massagem

[ ] meditação

[ ] cura espiritual, reiki

[ ] hipnose

[ ] florais, aromaterapia

[ ] dietas alternativas e terapias nutricionais

[ ] terapia em grupo, grupos de auto-ajuda

32. Para terminar, o(a) sr(a). gostaria de fazer algum comentário a respeito desta entrevista ou do assunto abordado por ela?

Terminamos. Doutor(a), obrigada pelo seu precioso tempo.

33. Qual a sua área de atuação?

34. Vamos passar agora para as perguntas sobre as práticas nãoconvencionais em medicina. Gostaria de lembrar que essas práticas são aquelas que não fazem parte da formação médica na graduação. São as chamadas medicinas ou terapias alternativas e vão desde técnicas usadas por médicos como acupuntura ou fitoterapia até métodos populares como a garrafada ou benzedeira passando pelas terapias oferecidas por centros esotéricos. Embora reconhecidas pelo Conselho Federal de Medicina, na definição que estamos usando, fazem parte a acupuntura e a homeopatia. De acordo?

Profissionalmente o(a) sr(a). já teve ou está tendo algum tipo de contato com práticas não-convencionais em medicina?

[ ] ] não 〉> passa para Q.36

[ ] $\operatorname{sim}$

35. Nesse caso, qual foi a impressão desse contato, boa, indiferente, ruim ou não sabe?

a) boa

b) indiferente

c) ruim

d) não sabe

36. Houve até agora, uso próprio dessas práticas, ou de algum familiar próximo?

[ ] ] não 〉> passa para Q.38

[ ] $\operatorname{sim}$ 
ANEXO A. Instrumento do estudo n' um: O questionário. - 4/4

37. Neste caso, qual foi a impressão deste contato: boa, indiferente, ruim ou não sabe?

a) boa

b) indiferente

c) ruim

d) não sabe

38. $\mathrm{O}$ (a) $\mathrm{sr}(\mathrm{a})$. percebe que existe demanda na sociedade leiga por estas práticas?

[ ] não

[ ] sim

39. Para o(a) sr(a)., estas práticas têm alguma ação sobre o resultado terapêutico?

[ ] não

[ ] sim, age positivamente

[ ] sim, age negativamente

[ ] não sabe

40. Bem, conversamos até aqui sobre seu contato com práticas não-convencionais em medicina. A seguir, gostaria de conhecer sua opinião de uma forma geral a respeito desse tipo de prática. Farei algumas afirmações sobre elas e diga se concorda ou discorda destas afirmações. $\mathrm{O}(\mathrm{a}) \mathrm{sr}(\mathrm{a})$. tem 6 opções para resposta:

$$
\begin{aligned}
& \text { •(1) concorda bastante } \\
& \text { •(2) concorda em parte } \\
& \text { •(3) indiferente } \\
& \text { •(4) discorda em parte } \\
& \text { •(5) discorda bastante } \\
& \text { •(9) não sabe }
\end{aligned}
$$

Nas afirmações, entende-se por elas as práticas não-convencionais em medicina. De acordo? Podemos começar?
[ ] "elas devem fazer parte da formação médica"
[ ] "elas devem ser usadas somente se forem científicas"
[ ] "elas são úteis no tratamento do paciente"
[ ] "elas são perigosas para a saúde do paciente"
[ ] "da maneira como elas são feitas, oferecem perigo para o paciente"
[ ] "elas prejudicam o tratamento convencional"
[ ] "elas fazem com que o paciente recuse o tratamento convencional"
[ ] "elas melhoram a qualidade de vida do paciente"
[ ] "elas melhoram o arsenal terapêutico do médico"
[ ] "elas devem ser combatidas pela classe médica"
[ ] "é importante o médico ter algum conhecimento delas"
[ ] "é importante o médico receber treinamento nelas"

41. Gostaria de conhecer seu nível de conhecimento em algumas práticas não-convencionais. Direi o nome de um tipo e o(a) $\operatorname{sr}(a)$. me responde se tem 'nenhum'(N), 'pouco'(P), 'algum'(A) ou 'bastante'(B) conhecimento. De acordo? Posso começar?
[ ] acupuntura
[ ] homeopatia
[ ] quiropatia ou manipulação de colunas
[ ] fitoterapia ocidental ou européia
[ ] medicina tradicional chinesa ou oriental
[ ] medicina biomolecular ou de radicais livres
[ ] massagem
[ ] meditação
[ ] cura espiritual, reiki
[ ] hipnose
[ ] florais, aromaterapia
[ ] dietas alternativas e terapias nutricionais
[ ] terapia em grupo, grupos de auto-ajuda

42. Para terminar, o(a) sr(a). gostaria de fazer algum comentário a respeito desta entrevista ou do assunto abordado por ela? 


\section{ANEXO B. Padronização de variáveis e de terminologias utilizadas no estudo. A listagem foi elaborada por ordem de surgimento no questionário.}

\begin{tabular}{|c|c|}
\hline variável ou terminologia & definição e/ou padronização \\
\hline práticas não-convencionais em medicina & $\begin{array}{l}\text { todo tipo de técnicas de diagnóstico, cuidados de saúde ou intervenções terapêuticas que } \\
\text { não fazem parte dos currículos acadêmicos da graduação, na maioria das escolas } \\
\text { médicas brasileiras; PNCM, neste estudo; }\end{array}$ \\
\hline local de nascimento & nome do município de nascimento e sua unidade da Federação; \\
\hline escola médica & nome da escola médica em que o médico se graduou e sua localização; \\
\hline formatura & ano da graduação em medicina; \\
\hline pós-graduação & $\begin{array}{l}\text { todo tipo de estudo ou treinamento relacionado a medicina que o indivíduo fez após a } \\
\text { graduação; }\end{array}$ \\
\hline Residência Médica & $\begin{array}{l}\text { curso de pós-graduação senso lato, reconhecido pelo Conselho Nacional de Residência } \\
\text { Médica, ao final do qual se obtém um Certificado de Residência Médica; }\end{array}$ \\
\hline Especialidade exceto Residência & $\begin{array}{l}\text { curso de especialização com mais de } 360 \text { horas de duração, exceto a Residência, ao } \\
\text { final do qual o médico obtém um Título de Especialista se fizer concurso ou prova de } \\
\text { conhecimento; }\end{array}$ \\
\hline Mestrado & $\begin{array}{l}\text { curso de pós-graduação senso estrito, em programas de pós-graduação reconhecidos } \\
\text { pelo Ministério de Educação, ao final do qual se obtém o título de Mestre em área } \\
\text { específica do conhecimento; }\end{array}$ \\
\hline Doutorado & $\begin{array}{l}\text { curso de pós-graduação senso estrito, reconhecido pelo MEC, mais avançado que o } \\
\text { mestrado, ao final do qual se obtém o titulo de Doutor em uma área do conhecimento, } \\
\text { o qual capacita o médico à execução e orientação de pesquisas; }\end{array}$ \\
\hline outros cursos & $\begin{array}{l}\text { qualquer outro curso realizado pelo médico que seja relavante para sua atividade médica } \\
\text { e que não possa ser definido pelos critérios acima mencionados; }\end{array}$ \\
\hline vínculo empregatício & são os vínculos profissionais de onde provêm o sustento do médico; \\
\hline servidor público & $\begin{array}{l}\text { funcionário de alguma entidade relacionada à saúde, mantido pelos governos federal, } \\
\text { estaduais ou municipais; }\end{array}$ \\
\hline profissional liberal & ou o médico autônomo; exerce a profissão por conta própria; \\
\hline assalariado no setor privado & $\begin{array}{l}\text { médico que exerce a profissão recebendo salário de entidades privadas, incluindo } \\
\text { fundações com vínculos em regime de CLT; }\end{array}$ \\
\hline empresário do ramo de saúde & $\begin{array}{l}\text { médicos empresários que empregam médicos; o proprietário de pessoa jurídica médica } \\
\text { que tenha médicos como sócios enquadra-se em profissional liberal; }\end{array}$ \\
\hline cooperado & $\begin{array}{l}\text { membro de uma associação prestadora de serviços médicos, em geral criadas dentro de } \\
\text { uma instituição, como hospital, ou dentro de uma comunidade; }\end{array}$ \\
\hline outros vínculos & $\begin{array}{l}\text { algum vínculo profissional que não se enquadra nas definições acima. Nesse caso, } \\
\text { anotar; }\end{array}$ \\
\hline vínculo principal & $\begin{array}{l}\text { em caso de ter mais de } 2 \text { vínculos, escolhido pelo sujeito, qual deles considera o } \\
\text { principal, nem tanto do ponto de vista de renda ou de tempo de trabalho mas aquele } \\
\text { que o médico se sente mais médico; }\end{array}$ \\
\hline tempo gasto no vínculo principal & tempo gasto no vínculo principal, proporcionalmente dentro de toda a atividade médica; \\
\hline tipo de atividade do vínculo principal & enquadrar em uma das três categorias; \\
\hline atividade clínica & atendimento a pacientes em estabelecimento; \\
\hline
\end{tabular}


docência ou pesquisa

atividade administrativa

outras atividades

local da atividade principal

clinica ou não

área de atuação como médico

generalista

especialista

contato profissional

contato particular

impressão do contato

opinião acerca de afirmações

familiaridade absoluta

familiaridade relativa

percebe demanda

influência para paciente

altera resultado para médico

age sobre resultado terapêutico

pergunta na anamnese

prescreve PNCM

provedor de PNCM

treinamento vinculado a uma instituição de ensino ou pesquisa, dá aulas ou trabalha com investigação, na área de biomedicina;

exerce função administrativa, de planejamento e organização, auditoria, consultoria, gerência ou direção de um estabelecimento de saúde;

atividades que não se enquadram nas três categorias acima referidas;

local onde é exercida a atividade que o médico considera a principal; a questão é aberta e deve ser anotada como o médico refere;

clinica, nesse caso, significa ter contato direto com pacientes e exercer a medicina por meio desse contato;

questão aberta e deve ser anotada a área que o médico mencionar; pode ser diferente da pós-graduação realizada;

o que o sujeito sente na maior parte do tempo e dentro da sua área de atuação como médico; o generalista tem uma visão geral do paciente mesmo exercendo algum tipo de especialidade médica;

também, o que o sujeito sente na maior parte do tempo e dentro da sua área de atuação como médico; o especialista tem uma visão mais segmentada do paciente mas com conhecimento mais aprofundado de uma determinada área do conhecimento em medicina;

qualquer tipo de contato com PNCM em ambiente profissional; pode ser uso, notícia, conhecimento;

qualquer tipo de contato com PNCM como paciente; o próprio médico ou de algum familiar próximo;

o sujeito deve responder conforme uma das categorias e a entrevistadora não deve interpretar a resposta;

ler claramente a afirmação e anotar a opção que o sujeito expressar dentro da Escala de Likert; por "elas" entendem-se as PNCM de uma maneira geral; a entrevistadora não deve interpretar as afirmações, se o sujeito não compreender a afirmação, repetir quantas vezes forem necessárias;

diz respeito à opinião da familiaridade absoluta do médico com relação a PNCM;

diz respeito à opinião da familiaridade já referida anteriormente, desta vez em comparação com os colegas;

o médico percebe a existência de demanda por parte da sociedade em geral e do paciente em particular;

pode trazer benefício ou malefício para o paciente, a resposta sim deve ser discriminada se positivamente ou negativamente;

pode trazer benefício ou malefício para o médico, a resposta sim deve ser discriminada se positivamente ou negativamente;

a ação sobre o resultado terapêutico, se existir pode ser positiva ou negativa;

pergunta sobre o uso prévio e atual de PNCM na anamnese; 'não se aplica' nos casos em que o médico tem contato com paciente mas não existe anamnese ou não existe possibilidade de uso prévio ou atual;

indica, endossa uso de PNCM na prática clínica; 'não se aplica' em ocupações que não há prescrição como radiologia;

o médico aplica o tratamento não-convencional proposto, prescrito;

existência de treinamento em PNCM, concluído ou em andamento; 
conclusão de treinamento

treinamento em academia

nível de conhecimento

acupuntura

homeopatia

quiropatia

fitoterapia européia

medicina oriental

medicina biomolecular

massagem

meditação

cura espiritual, reiki

hipnose

florais, aromaterapia

dietas

terapia em grupo

comentários conclusão do treinamento anteriormente referido;

realização do treinamento em questão em instituição acadêmica, ou seja, em escola médica, hospital universitário ou entidades afins;

é o referido pelo próprio médico, não existe teste de conhecimento; as PNCM foram selecionadas por conveniência do pesquisador;

técnica reconhecida pelo Conselho Federal de Medicina como especialidade médica visa restaurar o equilíbrio da energia corporal, através da inserção de agulhas e/ou aquecimento com moxas de pontos específicos para estimular, dispersar e regular a energia vital;

técnica reconhecida pelo Conselho Federal de Medicina como especialidade médica; baseado na estimulação do sistema imunológico com a administração de doses diluídas de substâncias vegetais, minerais ou animais usando-se do princípio "o similar cura o similar";

ou quiropraxia ou técnica de manipulação de colunas: técnica que visa resolver problemas de saúde através do alinhamento da espinha dorsal;

ou fitoterapia ocidental: tratamento de doença mediante o uso de plantas baseado na experiência popular de civilizações ocidentais;

ou medicina tradicional chinesa e suas escolas: racionalidade médica cuja origem remonta aos tempos antigos na China; sua técnica de cuidado da saúde combina o uso de ervas medicinais, acupuntura, dietas, massagem e exercício terapêutico;

ou ortomolecular ou de radicais livres: técnica em que procura administrar substâncias antioxidantes nos pacientes para bloquear ações de radicais livres no organismo, consideradas como causas de doenças;

ou massoterapia: tratamento que envolve a manipulação dos tecidos superficial e profundo bem como dos músculos, aplicando pressão com as mãos, braços, cotovelo, pés, promovendo a mobilização e alívio do stress e tensão muscular;

metodologia que propõe o uso da refexão mental para organização de energia corpórea;

método de cura que utiliza a energia espiritual; faz-se uso das mãos para canalizar a energia de cura ao recebedor; benzedura;

método que emprega a sugestão para resolver distúrbios mentais e comportamentais;

utiliza substâncias aromáticas, em extrato ou diluído, para ser tomado ou inalado para promover a saúde;

uso da dieta alimentar, de maneira científica ou não, na recuperação da saúde; inclui terapias nutricionais;

formas de tratamento que empregam técnicas de aconselhamento, vivências e troca de idéias entre os membros do grupo, em geral composto de indivíduos com o mesmo tipo de problema de saúde; inclui grupos de auto-ajuda;

anotar as frases ditas pelo entrevistado; o comentário pode ser a respeito da entrevista e/ ou do assunto PNCM. 


\section{ANEXO C. Critérios usados no estudo para categorização da variável 'área de atuação médica'.}

\begin{tabular}{|c|c|c|}
\hline categoria & explicação & área de atuação incluída \\
\hline especialidades clínicas & $\begin{array}{l}\text { O médico trabalha dentro de } \\
\text { consultório e/ou hospital e faz } \\
\text { diagnóstico valendo-se basicamente } \\
\text { do raciocínio clínico. Não opera e, } \\
\text { em geral, não há instrumental } \\
\text { cirúrgico em sua rotina. }\end{array}$ & $\begin{array}{l}\text { clínica geral; clínica médica e suas } \\
\text { subespecialidades, p. ex., neurologia, } \\
\text { endocrinologia, cardiologia, pneumolo- } \\
\text { gia, geriatria, intensivismo; infectologia, } \\
\text { hematologia, reumatologia; } \\
\text { homeopatia; oncologia clínica; } \\
\text { socorrismo (clínico); psquiatria }\end{array}$ \\
\hline especialidades cirúrgicas & $\begin{array}{l}\text { Trabalha em ambientes cirúrgicos e } \\
\text { opera. Demanda habilidade em uso } \\
\text { de instrumental específico. }\end{array}$ & $\begin{array}{l}\text { cirurgia geral; clínica cirúrgica e suas } \\
\text { subespecialidade, p. ex., neurocirurgia, } \\
\text { proctologia, urologia, cardiologia; } \\
\text { especialidades com base cirúrgicas, p. } \\
\text { ex. endoscopia; ortopedia e traumatolo- } \\
\text { gia e suas subespecialidades; oncologia } \\
\text { cirúrgica; socorrismo (cirúrgico) }\end{array}$ \\
\hline tocoginecologia & $\begin{array}{l}\text { Lida com as mulheres. Apesar de ser } \\
\text { uma área que opera, foi } \\
\text { categorizada à parte por se tratar de } \\
\text { uma das grandes áreas da medicina } \\
\text { e o grupo ser numeroso. }\end{array}$ & $\begin{array}{l}\text { ginecologia e obstetrícia e suas } \\
\text { subespecialidades, p. ex., mastologia, } \\
\text { reprodução humana }\end{array}$ \\
\hline pediatria & $\begin{array}{l}\text { Lida com crianças e adolecentes. A } \\
\text { exceção foi cirurgia pediátrica pois } \\
\text { sua formação é basicamente de } \\
\text { cirurgião. }\end{array}$ & $\begin{array}{l}\text { pediatria e suas subespecialidades, p. } \\
\text { ex., hebiatria, socorrismo e intensivismo } \\
\text { infantis, pneumopediatria, neuropedia- } \\
\text { tria, neonatologia }\end{array}$ \\
\hline outras especialidades & $\begin{array}{l}\text { São todas outras áreas citadas pelo } \\
\text { médicos e que não foram } \\
\text { categorizáveis com os critérios } \\
\text { referidos acima. }\end{array}$ & $\begin{array}{l}\text { anatomia patológica; anestesiologia; } \\
\text { imagenologia; dermatologia; otorrino- } \\
\text { laringologia; oftalmologia; acupuntura; } \\
\text { medicina nuclear; administração de } \\
\text { serviços de saúde; medicina do } \\
\text { trabalho; saúde pública; docente de } \\
\text { medicina; etc. }\end{array}$ \\
\hline
\end{tabular}


ANEXO D. Escolas de medicina da graduação da amostra estudada. O valor numérico referese à quantidade de ocorrências para cada escola. Foi utilizada a denominação atual da escola médica e/ ou da sua entidade mantenedora.

\begin{tabular}{|c|c|c|}
\hline Nome da Escola de Medicina & Localização & Ocorrências \\
\hline \multicolumn{3}{|c|}{ Faculdade de Medicina, Universidade de São Paulo... } \\
\hline \multicolumn{3}{|c|}{ 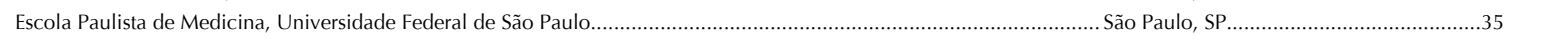 } \\
\hline \multicolumn{3}{|c|}{ Faculdade de Ciências Médicas da Santa Casa de São Paulo, Fundação Arnaldo Vieira de Carvalho.............................. São Paulo, SP......................................25 } \\
\hline \multicolumn{3}{|c|}{ Centro de Ciências Médicas e Biológicas, Pontifícia Universidade Católica de Sorocaba.. } \\
\hline \multicolumn{3}{|c|}{ 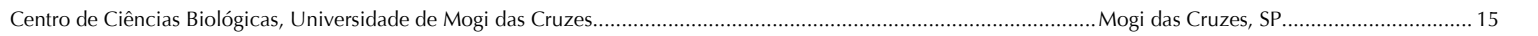 } \\
\hline \multicolumn{3}{|c|}{ 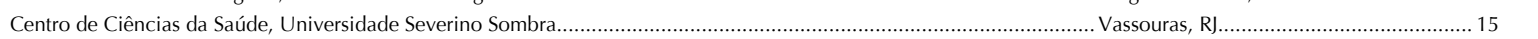 } \\
\hline \multicolumn{3}{|c|}{ Faculdade de Medicina do ABC, Fundação ABC... } \\
\hline \multicolumn{3}{|c|}{ Departamento de Medicina, Universidade de Taubaté... } \\
\hline \multicolumn{3}{|c|}{ 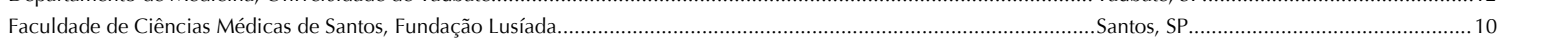 } \\
\hline \multicolumn{3}{|c|}{ 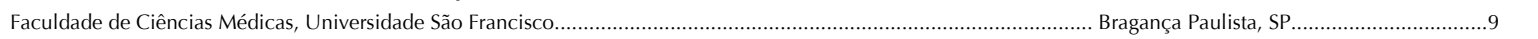 } \\
\hline \multicolumn{3}{|c|}{ 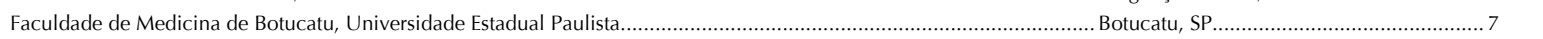 } \\
\hline \multicolumn{3}{|c|}{ Faculdade de Medicina de Ribeirão Preto, Universidade de São Paulo } \\
\hline \multicolumn{3}{|c|}{ Faculdade de Medicina, Universidade de Santo Amaro } \\
\hline \multicolumn{3}{|c|}{ Faculdade de Ciências Médicas, Pontifícia Universidade Católica de Campinas } \\
\hline \multicolumn{3}{|c|}{ 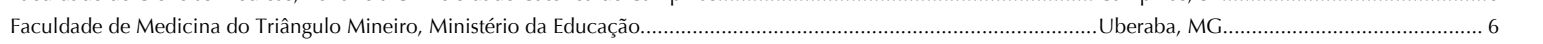 } \\
\hline \multicolumn{3}{|c|}{ 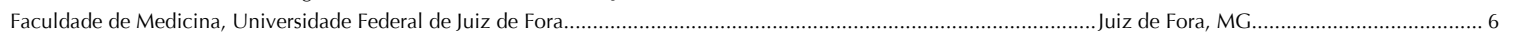 } \\
\hline Centro de Ciências da Saúde, Universida & 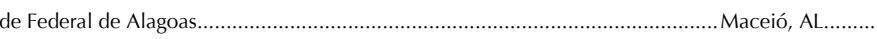 & $\ldots \ldots \ldots \ldots \ldots . . . .5$ \\
\hline Centro de Ciências da Saúde, Universida & de Federal de Pernambuco.................. & .................. 5 \\
\hline Faculdade de Ciências Médicas, Univers & idade Estadual de Campinas............. & \\
\hline Faculdade de Medicina, Universidade $\mathrm{F}$ & deral do Pará..................................... & $\ldots \ldots \ldots . . . . .5$ \\
\hline Faculdade de Medicina, Universidade & deral do Rio de Janeiro. & $\ldots \ldots \ldots$ \\
\hline Centro Biomédico, Universidade Federal & 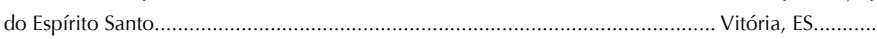 & \\
\hline Centro de Ciências Biológicas e da Saúde & e, Universidade Federal de Sergipe... & $\ldots \ldots \ldots \ldots . . . .4$ \\
\hline Faculdade de Ciências Médicas, Unive & idade do Estado do Rio de Janeiro........... & $\ldots \ldots \ldots \ldots \ldots . . .4$ \\
\hline Faculdade de Medicina de Itajubá, Assoc & iação de Integração Social de Itajubá... & $\ldots \ldots \ldots \ldots \ldots . . . .4$ \\
\hline Setor de Ciências da Saúde, Universid & e Federal do Paraná........ & $\ldots \ldots \ldots . . .4$ \\
\hline Centro de Ciências da Saúde, Fundação & Universidade Federal Maranhão................... & $\ldots \ldots \ldots \ldots \ldots . .3$ \\
\hline Centro de Ciências da Saúde, Universid & de Federal da Paraíba.................................... & $\ldots \ldots \ldots \ldots . . . .3$ \\
\hline Faculdade de Ciências Médicas, Fundaçã & áo Ensino Superior Vale do Sapucaí.. & \\
\hline Faculdade de Medicina de Catanduva, $\mathrm{F}$ & 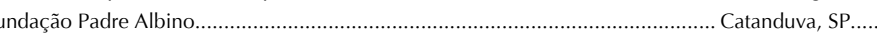 & ......... 3 \\
\hline Faculdade de Medicina de Jundiaí, Muni & cípio de Jundiaí... & \\
\hline Faculdade de Medicina de Marília, Fu & ação Municipal de Ensino Superior de Marília........................ & \\
\hline Faculdade de Medicina, Universidade d & ................... Brasília, DF.... & $\ldots \ldots \ldots \ldots \ldots . . .3$ \\
\hline Faculdade de Medicina, Universidade Fe & ........... Goiânia, GO.. & \\
\hline Faculdade de Medicina, Universidade Fe & deral de Minas Gerais............................................. & $\ldots \ldots \ldots . . .3$ \\
\hline Centro de Ciências Biológicas e da Saúde & 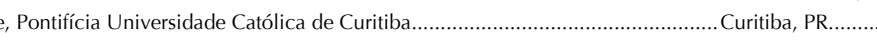 & $\ldots \ldots \ldots \ldots . .2$ \\
\hline Centro de Ciências Médicas e Biológica & 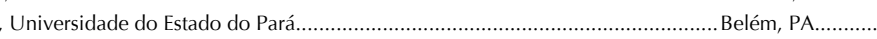 & \\
\hline Escola Bahiana de Medicina e Saúde Púb & lica, Fundação para Desenvolvimento das Ciências......... & $\ldots \ldots \ldots \ldots . .2$ \\
\hline Escola de Medicina, Fundação Técnico & 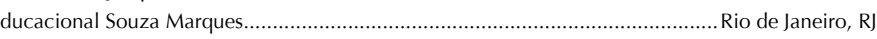 & $\ldots \ldots \ldots \ldots \ldots \ldots . .2$ \\
\hline Faculdade de Medicina de Campos, Func & 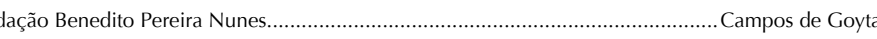 & \\
\hline Faculdade de Medicina de São José do R & io Preto, Fundação Faculdade Regional de Medicina.......................................... José do Rio & $\ldots \ldots \ldots \ldots \ldots . .2$ \\
\hline Faculdade de Medicina de Teresópolis, F & 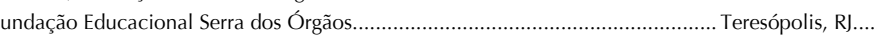 & \\
\hline Faculdade de Medicina, Pontifícia Unive & rsidade Católica do Rio Grande do Sul........................ & $\ldots \ldots \ldots . . .2$ \\
\hline Faculdade de Medicina, Universidade Fe & 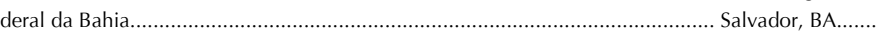 & \\
\hline Centro de Ciência de Saúde, Universid & 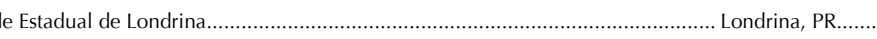 & \\
\hline Centro de Ciências Biológicas e da Saúde & e, Universidade Gama Filho.... & $\ldots \ldots \ldots \ldots . . .1$ \\
\hline Centro de Ciências da Saúde, Universida & 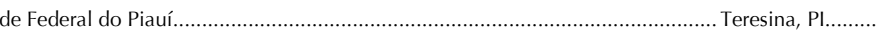 & ................. 1 \\
\hline Escola de Medicina, Escola Superior de C & iências da Santa Casa de Misericórdia de Vitória... & \\
\hline Faculdade de Ciências da Saúde, Univer & 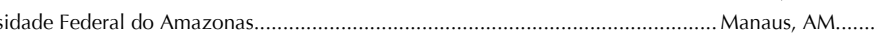 & $\ldots \ldots \ldots \ldots . . .1$ \\
\hline Faculdade de Ciências Médicas de Alfen & Universidade de Alfenas............................................ & \\
\hline Faculdade de Ciências Médicas de Minas & Gerais, Fundação Educacional Lucas Machado....... & \\
\hline Faculdade de Ciências Médicas, Univers & 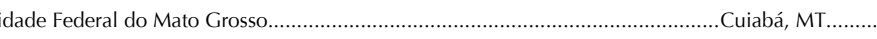 & $\ldots \ldots \ldots \ldots \ldots . . .1$ \\
\hline Faculdade de Medicina de Barbacena, $\mathrm{F}$ & 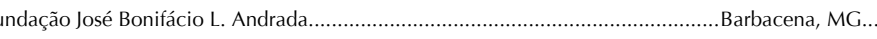 & \\
\hline Faculdade de Medicina de Petrópolis, F & 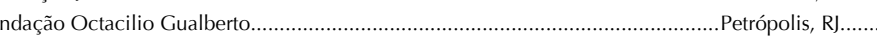 & ................... 1 \\
\hline Faculdade de Medicina de Valença, Func & dação Educacional Dom André Arcoverde.... & \\
\hline Faculdade de Medicina, Universidade Fe & 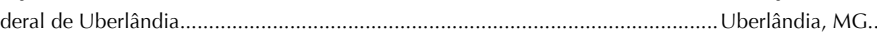 & \\
\hline Faculdade Evangélica do Paraná, Socied & ade Evangélica Beneficente de Curitiba........ & $\ldots \ldots \ldots \ldots \ldots . . .1$ \\
\hline Facultad de Ciencias Médicas, Universid & Católica de Santiago de Guayaquil.... & \\
\hline Facultad de Ciencias Médicas, Universid & 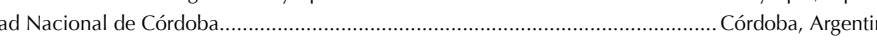 & $\ldots \ldots \ldots \ldots \ldots . . .1$ \\
\hline Facultad de Medicina Humana, Universi & dad Nacional Mayor de San Marcos ... & $\ldots \ldots \ldots \ldots \ldots \ldots$ \\
\hline Facultad de Medicina, Universidad Mayc & ......Cochabamba, & \\
\hline e Medicina, Universidad Sa & ......Sucre, Bolivi & \\
\hline
\end{tabular}


ANEXO E. Distribuição da opinião sobre afirmações acerca das PNCM em geral. n (\%). Total $=\mathbf{1 0 0} \%$.

\begin{tabular}{|c|c|c|c|c|c|c|c|c|c|c|c|c|c|}
\hline \multirow{3}{*}{$\begin{array}{l}\text { afirmações } \\
\text { A }\end{array}$} & \multicolumn{12}{|c|}{ opinião sobre afirmação acerca de PNCM como um todo } & \multirow{3}{*}{$\begin{array}{c}\text { total } \\
364\end{array}$} \\
\hline & \multicolumn{2}{|c|}{$\begin{array}{l}\text { concorda } \\
\text { bastante }\end{array}$} & \multicolumn{2}{|c|}{$\begin{array}{l}\text { concorda em } \\
\text { parte }\end{array}$} & \multicolumn{2}{|c|}{ indiferente } & \multicolumn{2}{|c|}{$\begin{array}{c}\text { discorda em } \\
\text { parte }\end{array}$} & \multicolumn{2}{|c|}{$\begin{array}{l}\text { discorda } \\
\text { bastante }\end{array}$} & \multicolumn{2}{|c|}{ não sabe } & \\
\hline & 71 & $(19,5)$ & 171 & $(47,0)$ & 15 & $(4,1)$ & 34 & $(9,3)$ & 69 & $(19,0)$ & 4 & $(1,1)$ & \\
\hline B & 238 & $(65,4)$ & 73 & $(20,0)$ & 10 & $(2,7)$ & 25 & $(6,9)$ & 16 & $(4,4)$ & 2 & $(0,6)$ & 364 \\
\hline C & 115 & $(31,6)$ & 181 & $(49,7)$ & 13 & $(3,6)$ & 22 & $(6,0)$ & 21 & $(5,8)$ & 12 & $(3,3)$ & 364 \\
\hline D & 30 & $(8,2)$ & 182 & $(50,0)$ & 8 & $(2,2)$ & 84 & $(23,1)$ & 44 & $(12,1)$ & 16 & $(4,4)$ & 364 \\
\hline$E$ & 61 & $(16,8)$ & 175 & $(48,1)$ & 4 & $(1,1)$ & 67 & $(18,4)$ & 33 & $(9,0)$ & 24 & $(6,6)$ & 364 \\
\hline $\mathbf{F}$ & 42 & $(11,6)$ & 130 & $(35,7)$ & 6 & $(1,6)$ & 96 & $(26,4)$ & 74 & $(20,3)$ & 16 & $(4,4)$ & 364 \\
\hline G & 42 & $(11,5)$ & 133 & $(36,5)$ & 11 & $(3,1)$ & 86 & $(23,6)$ & 83 & $(22,8)$ & 9 & $(2,5)$ & 364 \\
\hline $\mathbf{H}$ & 86 & $(23,6)$ & 185 & $(50,8)$ & 20 & $(5,5)$ & 21 & $(5,8)$ & 32 & $(8,8)$ & 20 & $(5,5)$ & 364 \\
\hline I & 99 & $(27,2)$ & 143 & $(39,3)$ & 8 & $(2,2)$ & 35 & $(9,6)$ & 65 & $(17,9)$ & 14 & $(3,8)$ & 364 \\
\hline J & 24 & $(6,6)$ & 71 & $(19,5)$ & 12 & $(3,3)$ & 90 & $(24,7)$ & 163 & $(44,8)$ & 4 & $(1,1)$ & 364 \\
\hline K & 245 & $(67,3)$ & 87 & $(23,9)$ & 8 & $(2,2)$ & 5 & $(1,4)$ & 16 & $(4,4)$ & 3 & $(0,8)$ & 364 \\
\hline $\mathbf{L}$ & 114 & $(31,4)$ & 115 & $(31,7)$ & 20 & $(5,5)$ & 47 & $(12,9)$ & 65 & $(17,9)$ & 2 & $(0,6)$ & 363 \\
\hline
\end{tabular}

Afirmações acerca das PNCMs em geral. "Elas" são as práticas não convencionais.

A "elas devem fazer parte da formação médica".

B "elas devem ser usadas somente se forem científicas".

C "elas são úteis no tratamento do paciente".

D "elas são perigosas para a saúde do paciente"

E "da maneira como elas são feitas, oferecem perigo para o paciente".

F "elas prejudicam o tratamento convencinal".

G "elas fazem com que o paciente recuse o tratamento convencional".

H "elas melhoram a qualidade de vida do paciente".

I "elas melhoram o arsenal terapêutico do médico".

J "elas devem ser combatidas pela classe médica".

K "é importante o médico ter algum conhecimento delas".

L "é importante o médico receber treinamento nelas". 


\section{ANEXO F. Registro de comentários feitos pelos entrevistados. (sexo, idade, área de atuação)}

\section{SOBRE O ESTUDO}

- O questionário foi muito claro, pesquisa válida. (M, 50, nefrologia) (M, 50, ortopedia e traumatologia)

- Achei o questionário adequado e abrangente. (M, 37, radiologia) (M, 56, psiquiatria)

- Foi ótimo participar do estudo. (M, 55, pediatria)

- Não dá para avaliar assim porque essas práticas são formas muito distintas. (M, 33, endocrinologia) (F, 32, pediatria ) (M, 39, neurologia clínica) (F, 52, oftalmologia)

- É difícil de responder de uma maneira geral para todas as práticas. (M, 55, clínica geral) (F, 47, homeopatia) (M, 43, cirurgia digestiva) (M, 65, clínica cirúrgica) (F, 37, dermatologia e acupuntura) (M, 50, clínica médica) ( $M, 41$, pediatria) $(M, 47$, clínica geral) $(F, 42$, acupuntura e neonatologia) $(M, 37$, reumatologia) $(M, 47$, dermatologia) (M, 52, gastroenterologia) (M, 56, anestesiologia)

- Algumas perguntas se tornam difíceis de responder por ter de fazer uma opção global. (M, 56, endocrinologia) (M, 42, cardiologia)

- Formular melhor a pergunta, as afirmações são ambíguas. (F, 45, ginecologia e obstetrícia) (M, 34, anestesiologia) (M, 27, cirurgia plástica) $(F, 33$, endocrinologia)

- O questionário foi mal formulado, misturou tudo; nem a medicina convencional é científica e hipnose não é medicina alternativa. (M, 62, ortopedia)

- Quem fez o questionário não fez bem feito, as perguntas estão mal formuladas pois algumas coisas a gente acredita, em outras não. (M, 52, urologia) (F, 52, ginecologia e obstetrícia)

- As PNCM são muito distintas e agrupá-las em uma pesquisa não vejo como possa chegar a um resultado. A comparação e análise em conjunto não vejo que leve a alguma conclusão. (M, 62, ortopedia)

- Lamento que estejam numa mesma cesta coisas diferentes do ponto de vista médico, não dá para opinar junto sobre essas diferentes coisas. ( $M, 53$, radiologia) ( $M, 64$, aposentado) ( $F, 41$, pediatria)

- Não gostei das perguntas genéricas porque há práticas que funcionam pois foram comprovadas e outras não. $(M, 43$, nefrologia) $(M, 26$, hematologia)

- Teria sido melhor se houvesse pergunta mais específica sobre alguns tipos de PNCM que são mais importantes de serem estudadas. ( $M, 58$, epidemiologia)

- O viés da pesquisa fica alterado misturando as práticas reconhecidas e as não-reconhecidas pelo CFM. (F, 34, otorrinolaringologia)

- A pesquisa deveria ter sido feita somente com práticas reconhecidas cientificamente. (M, 29, anestesiologia)

- Preferia ter respondido mais qualitativamente. (M, 47, clínica médica, homeopatia) (M, 52, saúde pública )

- O estudo é de extrema valia porque essas práticas existem e se mal usadas são perigosas. (M, 53, pediatria)

- Achei magnífico. Talvez seja interessante direcionar o resultado para especialistas que são sólidos em sua formação, diferem dos generalistas que vêem de tudo. (M, 72, clínica médica e cardiologia)

- Apesar de não fazer uso de PNCM, achei interessante este tipo de pesquisa pela época em que vivemos. (M, 
26, cirurgia geral)

- Qualquer tipo de pesquisa é importante. (M, 46, clínica médica)

- Não sei se vale a pena fazer pesquisa deste tipo, pode dar uma imagem falsa por ser genérica de mais. (M, 52, acupuntura) (M, 71, clínica médica)

- Achei válido para ter conhecimento do assunto. (M, 29, oncologia)

- Muito boa a iniciativa da Faculdade de Medicina da USP em estudar esse tema. Deveria fazer mais cursos com bom profissionais. ( $M, 54$, assessoria) ( $M, 58$, clínica médica e pediatria) ( $M, 43$, medicina de família)

- É interessante que a universidade tome conhecimento e divulgue para a classe médica. (M, 50, cirurgia e acupuntura) ( $M, 40$, recusou informação)

- É super interessante um grupo se interessar em fazer um estudo desse. (F, 42, anestesiologia) (M, 36, urologia) ( $M, 56$, clínica médica e gastroenterologia)

- Achei válida a pesquisa porque vi que existem perguntas que são importantes de serem feitas para o paciente, é para avaliar o estado psicológico do paciente. (M, 37, ginecologia e obstetrícia)

- O estudo contribui para maior estruturação dos cursos em faculdades de medicina. (M, 53, psiquiatria)

- Tenho muito receio da conclusão que será tirada. (M, 37, neurocirurgia)

\section{SOBRE O ASSUNTO ESTUDADO}

- Elas devem ser estudadas pela classe médica. (M, 54, infectologia)

- Práticas alternativas pressupõe curandeirismo e não medicina. (F, 46, homeopatia)

- Acho importante estudar o assunto, existem e são usadas. (F, 37, neuropediatria) (M, 53, psiquiatria)

- Acho interessante chamar a atenção dos médicos para essas práticas. (M, 73, endocrinologia)

- O importante é serem exercidas por médicos e não por leigos, esse é o problema. (M, 34, anestesiologia)

- Deve ser feita por quem entende do assunto. (M, 47, cirurgia geral)

- Tem que ter na graduação algo sobre o assunto. (M, 30, clínica médica e cardiologia) (M, 45, clínica médica) (M, 29, otorrinolaringologia)

- Devem ser ensinadas para os médicos saberem diferenciar tabus e práticas válidas. (M, 49, pediatria)

- É preciso que os médicos tenham algum conhecimento nessas práticas pois há procura e também muitos tabus. (F, 30, medicina de família)

- O assunto está em evidência na mídia e precisa ser desmistificado. A maioria atrapalha o trabalho médico. (M, 48, ortopedia)

- O assunto é atual. Eu lamento não conhecer mais, é preciso partir para novas formas de terapêuticas. (F, 47, ginecologia e obstetrícia)

- É necessário que a classe médica conheça o assunto para torná-la científica. (F, 53, medicina de família)

- Deve fazer parte da formação médica se for reconhecida cientificamente. (F, 46, pediatria e homeopatia) 
- Deve fazer parte da formação médica uma vez regulamentada. (M, 48, patologia)

- Não gosto de medicina alternativa. (F, 47, pronto socorro)

- Sou totalmente contra as PNCM, sou totalmente alopata. (M, 50, clínica médica)

- Nego todas essas práticas. É importante o médico ter conhecimento para saber que é ruim. (M, 71, ginecologia)

- O CFM deveria se posicionar melhor quanto a essas práticas. Acredito em acupuntura, homeopatia e fitoterapia, o resto é picaretagem. (F, 52, ginecologia e obstetrícia)

- Com a acupuntura concordo mas com outras práticas sou totalmente contra. Aliás, a acupuntura nem deveria ter sido incluida como PNCM. (M, 31, ortopedia)

- As PNCM devem ser ensinadas na faculdade e se o aluno tiver interesse, deve buscar conhecimento após a graduação. (M, 38, pediatria)

- Acho que deve ser utilizadas para o crescimento pessoal e intelectual do médico. Cada um deve procurar e não tem que ser curricular não. (M, 43, ginecologia e obstetrícia)

- Isso tudo é só demanda induzida. Só aceito o uso de práticas reconhecidas pelo Conselho e uso como tratamento complementar. (M, 61, consultoria e perícia)

- Todas essas práticas, junto com a medicina ocidental, podem contribuir para a cura dos pacientes como um todo. Claro, levando-se em consideração o respaldo científico para essas práticas. (F, 46, pediatria) (M, 35, cirurgia plástica)

- Algumas terapias não podem ser misturadas num saco só. (F, 47, homeopatia), (F, 46, homeopatia) (M, 50, pediatria)

- Não pode generalizar. Defendo o uso de práticas reconhecidas cientificamente, a acupuntura e a homeopatia. Dependendo da prática, ajuda o paciente. (M, 41, psiquiatria) (M, 40, reumatologia)

- Destacar a importância da acupuntura e homeopatia e por serem reconhecidas, deveriam fazer parte da formação do médico. (F, 35, otorrinolaringologia)

- A medicina alopática deveria abranger essa parte da homeopatia e acupuntura e incluir no currículo. (F, 38, ultrassonografia)

- Precisaria ter perguntado separadamente de homeopatia e acupuntura. (M, 35, cirurgia geral) (F, 34, otorrinolaringologia) (M, 50, ortopedia e traumatologia) (M, 29, anestesiologia)

- Homeopatia e acupuntura não são mais consideradas alternativas. (M, 54, assistência domiciliar) (M, 45, UTI) (M, 54, cirurgia geral)

- Homeopatia e acupuntura são quase convencionais. (M, 46, psiquiatria)

- Várias práticas já são cientificamente aceitas, outras não. (M, 44, ginecologia e obstetrícia) (F, 42, clínica médica)

- Algumas delas já tem conhecimento científico e outras se tem pouco conhecimento. (F, 35, cirurgia plástica) (M, 39, psiquiatria)

- Acupuntura e homeopatia já são científicas. (M, 58, ortopedia )

- Tenho bastante resistência em aderir a práticas alternativas. Acredito na alopatia, em segundo lugar acredito na medicina chinesa e homeopatia, são um pouco mais provados que funcionam, mas o restante não. $(\mathrm{F}, 44$, 
administração hospitalar)

- A maioria da população desconhece essas práticas. Há necessidade de saber se a crença do paciente contribui para o tratamento. $(M, 50$, gerência médica)

- Como são diversas e conheço apenas algumas, fica difícil responder genericamente. (M, 34, cirurgia geral)

- As respostas para algumas questões são as experiências pessoais dentro da minha área. (F, 45, dermatologia)

- Vejo com preocupação a adesão cega a essas práticas, creio que há limites e os tratamentos devem ser conjuntos. (M, 46, clínica médica)

- Elas mascaram alguns diagnósticos. (F, 42, oftalmologia)

- Acho que as PNCM pode influenciar negativamente no resultado terapêutico para o paciente pois não há controle dessas práticas. Elas podem funcionar como cortina de fumaça e atrapalha o tratamento convencional trazendo prejuízo para a saúde do paciente. (M, 59, pediatria)

- Desconheço como funciona mas acho importante seguir se for cientificamente comprovado. (M, 54, medicina de família)

- Todas as práticas alternativas em medicina podem ser realizadas desde que tenham embasamento científico. ( $M, 41$, ginecologia e obstetrícia)

- É um absurdo a PNCM sem fundamentação científica. (M, 35, oftalmologia)

- A PNCM nunca me atraiu. Acho o assunto muito vago. Mas acho interessante que o assunto seja estudado. (M, 73, perícia acidentária)

- Reiki é bobagem. (F, 45, ginecologia e obstetrícia)

- O assunto é interessante dependendo da área em que o médico atua. (M, 50, medicina do trabalho)

- Se mal aplicadas, podem ser perigosas para a saúde do paciente. (M, 49, coordenação administrativa)

- Há poucos profissionais capacitados que inspire confiança. (M, 40, reumatologia)

- Podem prejudicar o tratamento convencional se houver exagero. (M, 57, administração de serviço de saúde)

- Deve-se realmente continuar a pesquisa pois a medicina tradicional precisa da medicina oriental para tratar melhor o paciente. (M, 60, nefrologia e medicina)

- As práticas são muito diferentes mas acho que todas tem o seu espaço. (M, 54, cirurgia geral)

\section{SOBRE O MÉDICO}

- O médico deveria ter contato com medicina alternativa de uma maneira até mais aprofundada para avaliar e analisar as condições do paciente e para melhorar sua capacidade (do médico).(M, 50, pediatria)

- O assunto é interessante e os médicos devem pesquisar e ter conhecimento sobre essas práticas. (M, 53, ginecologia e obstetrícia) (F, 33, ginecologia e obstetrícia)

- Essas práticas já se difundiram bastante, os pacientes fazem muito uso e os médicos não tem conhecimento para saber lidar com essas situações. (F, 31, endocrinologia)

- Creio que deve ser discriminado o charlatanismo e os médicos são os melhores indicados para avaliar essas 
terapias sem que haja preconceito, o que noto ser muito forte na classe médica. (M, 53, cirurgia geral)

- Você deve associar as diferentes práticas para ajudar o paciente. (M, 47, dermatologia)

- Acho que o assunto PNCM deveria fazer parte do curso de medicina para os médicos poderem orientar e indicar melhor. (M, 27, clínica médica) $(F, 42$, pediatria)

- Seria importante introduzir nos cursos de graduação, noções básicas sobre cada prática para conhecer indicações e utilidades do uso pelo paciente. (F, 43, pediatria) (F, 42, ginecologia e obstetrícia) (F, 30, endocrinologia)

- Todo estudante de medicina deveria aprender essas práticas para auxiliar no tratamento convencional. (F, 60, pediatria) (F, 43, ginecologia e obstetrícia) (F, 52, dermatologia)

- Acho que a medicina alternativa atrapalha sim a prática médica e deveria haver aula sobre o assunto na graduação. (M, 47, cardiologia)

- Algumas terapias têm que ser feitas por médicos ou com o aval de um. (M, 29, patologia clínica)

- Acho que o médico da terapia alternativa não examina o paciente mas não tenho conhecimento profundo. (M, 75, ensino médico em clínica médica)

- Muita gente critica certos tipos de práticas sem conhecer o assunto. (M, 47, pediatria)

- Acho difícil pessoas de outras especialidades opinarem a respeito. (M, 35, ortopedia)

- Acho que deve ser discutida com outros profissionais. (M, 75, clínica médica)

- Tem muita gente fazendo coisas que não tem aptidão para isso, é importante estudar. (F, 48, dermatologia)

- Deve-se começar a olhar o currículo médico para oferecer conhecimento dessas práticas porque dever ter coisas úteis já que são usadas há milênios como na acupuntura. (M, 46, clínica médica e geriatria)

- A finalidade da medicina é curar o paciente. Qualquer técnica que auxilie o paciente deve ser respeitada, não devemos contrariá-lo se ele se dá bem com determinado tratamento. (M, 79, medicina psicossomática)

- Eu não pratico mas não condeno quem pratica, principalmente em situações que trazem benefícios ao paciente. $(\mathrm{F}, 46$, ginecologia)

- A medicina só tem a ganhar com este tipo de preocupação. Abrir espaço afinal, é ganho de cura do paciente independentemente de qual prática. $(\mathrm{F}, 46$, dermatologia)

- Li muito pouco a respeito, só tenho algum conhecimento. Acho que os médicos mais jovens vão se beneficiar mais. ( $\mathrm{M}, 74$, aposentado)

- É bom que alguém está interessado em uma prática mais responsável. O médico ainda vê essas práticas de uma forma muito obscura. (M, 43, clínica médica e UTI) (M, 57, homeopatia)

- A proliferação das práticas se dá por carência nas questões humanas no tratamento convencional. (M, 52, saúde pública) (M, 75, professor de medicina)

\section{SOBRE A EXPERIÊNCIA COM PNCM}

- Não tive nada disso na minha formação médica. (M, 48, clínica médica e cardiologia) (M, 52, anestesiologia e 
UTI)

- Não sei de nada a respeito dessa área. (M, 48, clínica médica e geriatria)

- A conversa médica é um grande remédio e PNCM funciona nas doenças psicossomáticas. (M, 48, cardiologia) ( $M, 75$, ensino médico em clínica médica)

- São úteis para o paciente. (M, 54, cardiologia)

- Em alguns casos considero essas práticas úteis, em muitos não. (M, 38, nefrologia) (M, 35, oftalmologia)

- Fiz cursos, então conheço um pouco. Há práticas boas e outras ruins, 80\% dos homeopatas são picaretas. (M, 40 , ginecologia)

- Tenho bastante conhecimento em algumas práticas e estou convencido que elas não servem para nada logo não concordo. (M, 37, neurocirurgia)

- Algumas técnicas são interessantes mas acho que sempre devem ser aplicadas por médicos com mais conhecimento. Também existe o perigo dos não médicos. (F, 47, pediatria)

- Algumas práticas reconhecidas são muito úteis, outras como benzedeira vou mandar longe. (M, 34, geriatria)

- Existem práticas boas e outras ruins, usei acupuntura e homeopatia e encaminho para acupuntura. (F, 36, UTI)

- Acupuntura tem embasamento científico. (M, 44, clínica médica e infectologia)

- Eu prescrevo acupuntura como coadjuvante do tratamento convencional. (M, 42, psiquiatria)

- Funciona como complemento. (F, 52, aposentado) (F, 27, ginecologia e obstetrícia) (M, 37, urologia))

- Dietas alternativas e fitoterapia podem influenciar no andamento da doença infecciosa, por isso sempre pergunto. (M, 44, clínica médica e infectologia)

- Tem ação indireta e age bem no aspecto psicológico. (M, 71, neurologia infantil)

- Elas podem ajudar psicologicamente. (M, 53, ginecologia e obstetrícia) (F, 35, cirurgia plástica) (F, 46, ginecologia)

- Tem efeito placebo. (M, 67, pediatria) (F, 43, ginecologia e obstetrícia)

- Eu indico homeopatia, e fiz também curso de acupuntura. (F, 37, pediatria)

- Nem sempre elas prejudicam o tratamento convencional mas sim, pode prejudicar. (M, 42, psiquiatria)

- Às vezes os pacientes se automedicam e atropelam o tratamento convencional. (M, 53, nefrologia)

- Os pacientes procuram a terapia alternativa quando não tem mais jeito. (M, 33, cirurgia de cabeça)

- Tenho treinamento em acupuntura. (F, 52, clínica médica)

- Concordo com acupuntura e reiki. (M, 52, gastroenterologia)

- Prescrevo acupuntura. (F, 42, oftalmologia) (M, 47, ortopedia e traumatologia) (M, 58, clínica médica) (M, 52, ortopedia) (F, 31, endocrinologia) (F, 27, clínica médica) (M, 64, cirurgia do aparelho)

- Prescrevo acupuntura. Dependendo do caso, funciona. (F, 34, dermatologia)

- Acupuntura funciona. (M, 56, anestesiologia)

- Tive contato profissional com acupuntura. (F, 32, ginecologia e obstetrícia)

- Venho tendo boa impressão profissional com acupuntura e homeopatia. (M, 45, UTI) 
- Tive contato com algumas PNCM quando atuei como clínico geral. Tenho treinamento em homeopatia e acupuntura. (M, 49, anestesiologia)

- Tenho treinamento em homeopatia e fiz um pouco de curso de acupuntura. (M, 42, cirurgia pediátrica)

- Tive treinamento e prescrevo homeopatia. (F, 50, ginecologia e obstetrícia)

- Tenho treinamento em homeopatia e encaminho para acupuntura e homeopatia. (F, 43, clínica médica)

- Prescrevo homeopatia. (M, 35, cirurgia plástica)

- A homeopatia teve algum resultado em certas doenças. (F, 42, clínica médica)

- Aceito acupuntura, fitoterapia e homeopatia e estou tendo treinamento nestas práticas. (F, 46, pediatria)

- Tive treinamento em medicina ortomolecular. O paciente se sente melhor com uso de PNCM. (F, 35, dermatologia)

- Eu estou muito bem impressionado com acupuntura, passei por um tratamento bem sucedido. Mas sou descrente da homeopatia, florais e ortomolecular. (M, 59, pediatria)

- Acho que alguns casos ajudam bastante na recuperação do paciente. Encaminho para acupuntura e fitoterapia. (F, 40, ginecologia e obstetrícia)

- Recomendo acupuntura e massagem paralelamente ao tratamento fisioterápico dos pacientes. (M, 42, ortopedia)

- Prescrevo massagem, meditação e grupos de auto ajuda. (M, 46, psiquiatria)

- O resultado terapêutico depende do caso. Tem paciente que o tratamento convencional não ajuda, nesses casos, desde que bem feito, tudo é válido como arsenal médico. (M, 30, ortopedia)

- Eu inclusive, os médicos conhecem pouco o assunto. Nas vezes que tive contato com PNCM pelos pacientes que usavam, achei que o uso delas atrapalhava o tratamento convencional, exceto a acupuntura. $(\mathrm{F}, 25$, ginecologia)

- Devido ao uso de práticas alternativas, muitas vezes o paciente larga o tratamento convencional. (M, 52, medicina do trabalho)

- As terapias são de apoio mas falham pois não há triagem médica clássica, às vezes tratam os sintomas. O risco não é fazer a terapia alternativa em si mas só ficar nisso. Já vi situações graves com cirurgia espiritual. (M, 48, UTI)

- Pode ter ação positiva se o profissional for competente. (M, 51, perícia médica)

- Sou espírita e tem cura sim pela parte espiritual. Mas não é muito abordado. (F, 54, oftalmologia)

- Eu recebo pacientes graves que chegam nesse estado devido a essas crenças. Já vi várias pessoas que usam homeopatia e tem resistência a tomar antibióticos e chegam piores no hospital. (F, 38, pediatria e UTI neonatal)

- Já tive de boa até péssima impressão sobre essas práticas. (M, 52, psiquiatria)

- Faço uso próprio de acupuntura mas acho que não está dando resultado. (F, 55, clínica geral) (F, 46, dermatologia)

- Encaminho para produtos naturais, cosmética e acupuntura. (F, 35, dermatologia) 
- Considero minha área, a medicina estética, uma prática não-convencional. (F, 42, clínica médica)

- Aplico somente acupuntura mas acho que tenho muito que aprender ainda. (F, 37, dermatologia e acupuntura)

- Encaminho para acupuntura e já fui provedor. (M, 51, clínica médica e ginecologia)

- Prescrevo fitoterapia. (F, 53, pronto socorro) (F, 29, ginecologia e obstetrícia) (M, 52, clínica médica) (M, 37, urologia)

- Tenho treinamento em fitoterapia e faço fitoterapia, acupuntura e homeopatia. (M, 54, clínica geral)

- Tive boa impressão com uso particular de fitoterapia. (M, 58, ginecologia e obstetrícia)

- Às vezes uso fitoterapia mas sou mais medicina convencional. (F, 53, pediatria)

- Gostaria que fosse diferenciada na pesquisa a hipnose, terapia em grupo e grupos de auto-ajuda pois essas indico para o paciente. (M, 39, psiquiatria)

- Trabalho com crianças e são pacientes em que não se aplicam essas práticas. (F, 34, pediatria)

- Todas funcionam em quadros de doença vira ou psíquica que se dão em 90\% das doenças. Então vai ter resultado. O problema está com os $10 \%$ restantes para as quais não dá resultado. (M, 49, pediatria)

- Não interferem muito no meu trabalho por isso não tenho muito conhecimento. (M, 66, oftalmologia)

- O uso depende do nível econômico do paciente, essas práticas são pouco divulgadas e caras. (M, 52, pediatria e pronto socorro)

- Estou me submetendo a tratamento com acupuntura. (M, 37, reumatologia) (F, 43, ginecologia e obstetrícia) (F, 52, oftalmologia)

- Difícil saber se tem alguma ação pois muitas pessoas tem acompanhamento médico junto. $(\mathrm{F}, 30$, medicina de família)

- Eu tenho preocupação com a fundamentação científica dessas práticas. Prescrevo RPG, tenho treinamento em homeopatia e odeio ortomolecular. O problema é o mau uso dessas práticas. $(\mathrm{F}, 43$, clínica médica e cardiologia)

- Vejo o reflexo dessas práticas mal feitas que levam atá a óbito, o médico tem que estudar para saber usar. (F, 47, anatomia patológica)

- Reduz custos e melhora a relação médico-paciente. (M, 43, medicina de família) 


\section{8 - REFERÊNCIAS}

Aakster, C.W. Concepts in alternative medicine. Soc Sci Med. 1986;22:265-73

Akiyama, K. Perfil dos usuários de serviço de medicina não-convencional: um estudo da população que procura o Setor de Medicina Chinesa - Acupuntura do Hospital São Paulo- UNIFESP (dissertação). São Paulo: Escola Paulista de Medicina, Universidade Federal de São Paulo;1999.

Anatel - Agência Nacional de Telecomunicações. Relatório anual 2001. Brasília, ANATEL, 2002.

Astin, J.A. Why patients use alternative medicine: results of a national survey. JAMA. 1998;279:1548-53.

Astin, J.A.; Marie, A.; Pelletier, K.R.; Hansen, E.; Haskell, W.L. A review of the incorporation of complementary and alternative medicine by mainstream physicians. Arch Intern Med. 1998;58:2303-10.

Barnes, L.L. The Acupuncture Wars: The Professionalizing of American Acupuncture-A View From Massachusetts. Medical Anthropology. 2003;22:261-301.

Barnes ,P.M.; Powell-Griner, E.; McFann, K.; Nahin, R.L. Complementary and alternative medicine use among adults: United States, 2002. Advanced data; $n^{\circ} 343$, Hyattville: National Centers for Health Statistics. 2004.

Best, A. e Herbert, C. Two solitudes of complementary and conventional medicine: where are we going? Editorial. Can Fam Physician. 1998;44:953-5.

Beyerstein, B. Alternative medicine: where's the evidence? Editorial. Can J Public Health. 1997;88:149-50.

Bourdieu, P. O poder simbólico. Rio de Janeiro: Bertrand Brasil; 2002:59-73.

Campion, E.W. Why unconventional medicine? Editorial. N Eng J Med. 1993;328:282-3.

CRM critica lei municipal de terapias naturais. O Estado de S.Paulo, São Paulo. 2004 fev 17:A11.

Dalen, J.E. "Conventional" and "Unconventional" medicine: can they be integrated? Editorial. 
Arch Intern Med. 1998;58:2179-81.

Dantas, F. Ética e Pesquisa num Contexto de Incerteza. Jornal do CFM, Brasília. 1999, março.

Davidoff, F. Weighing the Alternatives: Lessons from the Paradoxes of Alternative Medicine. Editorial. Ann Intern Med. 1998;129:1068-70 .

Dicionário houaiss da língua portuguesa. Rio de Janeiro: Objetiva; 2001.

Eisenberg, D.M. Advising patients who seek alternative medical therapies. Ann Inter Med. $1997 ; 127: 61-9$.

Eisenberg, D.M.; Kesseler, R.C.; Foster, C.; Norlock, F.E.; Calkins, D.R.; Delbanco, T.L. Unconventional medicine in the United States - Prevalence, costs and patterns of use. N Eng J Med. 1993;328:246-52.

Fontanarosa, P.B. Publication of complementary and alternative medicine research in mainstream biomedical journals. J Altern Complement Med. 2001;7(Suppl1):S139-43.

Goldbeck-Wood, S.; Dorozynski, A.; Lie, L.G.; ET AL. Complementary medicine is booming worldwide. BMJ. 1996;313:131-3.

Heidelberg, A.T. Three out of four Germans have used complementary or natural remedies. BMJ. 2002;325:990.

Jonas, W.B. Alternative medicine: learning from the past, examining the present, advancing to the future. Editorial. JAMA. 1998;280:1616-8.

Kellerman, S.E.; Herold, J. Physician Response to Surveys: a Review of the Literature. Am J Prev Med. 2001;20:61-7.

Konefal, J. The Challenge of Educating Physicians about Complementary and Alternative Medicine. Academic Medicine. 2002;77:847-50.

Le Bon, G. As opiniões e as crenças. São Paulo: Ícone; 2002.

Lotufo, P.A. Não há alternativa à Medicina: diga sim ao sim; diga não ao não. Diagn tratamento. Editorial. 2001;6:3-4.

Millar, W.J. Use of alternative health care practitioners by Canadians. Can J Public Health. 1997;88:154-8.

Muhib, F.B.; Lin, L.S.; Stueve, A.; Miller, R.L.; Ford, W.L.; Johnson, W.D.; Smith, P.J. A venuebase method for sampling hard-to-reach populations. Public. Health Rep. 2001;116:216-22.

Murray, R.H. e Rubel, A.J. Physicians and healers: unwitting partners in health care. N Eng J Med. 1992;326:61-4.

Owen, D.K.; Lewith, G.; Stephens, C.R. Can doctors respond to patients' increasing interest in complementary and alternative medicine? BMJ. 2001;322:154-8. 
Rees, L.; Weil, A. Integrated medicine. BMJ. 2001;322:119-20.

Salim-Silva, M.; Smith, W.T.; Bammer G. Telephone reminders are a cost effective way to improve responses in postal health surveys. J Epidemiol Community Health. 2002;56:115-8.

Schraiber, L.B. O médico e seu trabalho. São Paulo: Hucitec; 1993.

Sikand, A.; Laken, M. Pediatricians' Experience With and Attitudes Toward Complementary/ Alternative Medicine. Arch Pediatr Adolesc Med. 1998;152:1059-64.

Spencer, J.; Jonas,W. And Now, Alternative Medicine. Editorial. Arch Fam Med. 1997;6:155-6.

Straus, S.E. Complementary and alternative medicien: challenges and opportunities for American Medicine. Acad Med. 2000;75:572-3.

Studdert, D.M.; Eisenberg, D.M.; Miller, F.H.; Curto, D.A.; Kaptchuk, T.J.; Brennan, T.A. Medical malpractice implications of alternative medicine. JAMA. 1998;280:1610-5.

Sugarman, J. e Burk, L. Physicians' ethical obligations regarding alternative medicine. JAMA. 1998;280:1623-5.

Thomas, K.J.; Coleman, P.; Nicholl, J.P. Trends in access to complementary or alternative medicines via primary care in England: 1995-2001 results from a follow-up national survey. Family Practice. 2003;20:575-7.

Thompson, W.G. Alternatives to medicine. Editorial. Can Med Assoc J. 1990;142:105-6.

Vickers, A. Complementary medicine. BMJ. 2000;321:683-6.

Visser, G.J.; Peters, L.; Rasker, J.J. Rheumatologists and their patients who seek alternative care - An agreement to disagree. Br J Rheumatol. 1992;31:485-490

Weil, A. Integrated Medicine BMJ. 2001;322:119-20.

Winslow, L.C.; Shapiro, H. Physicians want education about complementary and alternative medicine to enhance communication with their patients. Arch Iter Med. 2002;162:1176-81.

WHO. Tradicional medicine strategy 2002-2005. Geneva:WHO;2002.

WHO. Traditional medicine. Fact Sheet $N^{\circ} 134.2003$ mai 01: 1-3. 